\title{
SUBTASK 3.9 - DIRECT COAL LIQUEFACTION PROCESS DEVELOPMENT
}

Final Report

(for the period of March 1, 2010, through July 31, 2012)

Prepared for:

AAD Document Control

National Energy Technology Laboratory

U.S. Department of Energy

626 Cochrans Mill Road

PO Box 10940, MS 921-107

Pittsburgh, PA 15236-0940

Cooperative Agreement No.: DE-FC26-08NT43291

DOE Technical: Steven Markovich

Prepared by:

Ted R. Aulich

Ramesh K. Sharma

Energy \& Environmental Research Center

University of North Dakota

15 North 23rd Street, Stop 9018

Grand Forks, ND 58202-9018 


\section{DISCLAIMER}

This report was prepared as an account of work sponsored by an agency of the United States Government. Neither the United States Government, nor any agency thereof, nor any of their employees, makes any warranty, express or implied, or assumes any legal liability or responsibility for the accuracy, completeness, or usefulness of any information, apparatus, product, or process disclosed, or represents that its use would not infringe privately owned rights. Reference herein to any specific commercial product, process, or service by trade name, trademark, manufacturer, or otherwise does not necessarily constitute or imply its endorsement, recommendation, or favoring by the United States Government or any agency thereof. The views and opinions of authors expressed herein do not necessarily state or reflect those of the United States Government or any agency thereof.

\section{EERC DISCLAIMER}

LEGAL NOTICE This research report was prepared by the Energy \& Environmental Research Center (EERC), an agency of the University of North Dakota, as an account of work sponsored by the U.S. Department of Energy and Accelergy Corporation. Because of the research nature of the work performed, neither the EERC nor any of its employees makes any warranty, express or implied, or assumes any legal liability or responsibility for the accuracy, completeness, or usefulness of any information, apparatus, product, or process disclosed or represents that its use would not infringe privately owned rights. Reference herein to any specific commercial product, process, or service by trade name, trademark, manufacturer, or otherwise does not necessarily constitute or imply its endorsement or recommendation by the EERC. 


\title{
SUBTASK 3.9 - DIRECT COAL LIQUEFACTION PROCESS DEVELOPMENT
}

\begin{abstract}
The Energy and Environmental Research Center (EERC), in partnership with the U.S. Department of Energy (DOE) and Accelergy Corporation, an advanced fuels developer with technologies exclusively licensed from ExxonMobil, undertook Subtask 3.9 to design, build, and preliminarily operate a bench-scale direct coal liquefaction (DCL) system capable of converting 45 pounds/hour of pulverized, dried coal to a liquid suitable for upgrading to fuels and/or chemicals. Fabrication and installation of the DCL system and an accompanying distillation system for off-line fractionation of raw coal liquids into 1) a naphtha-middle distillate stream for upgrading and 2) a recycle stream was completed in May 2012. Shakedown of the system was initiated in July 2012. In addition to completing fabrication of the DCL system, the project also produced a 500-milliliter sample of jet fuel derived in part from direct liquefaction of Illinois No. 6 coal, and submitted the sample to the Air Force Research Laboratory (AFRL) at WrightPatterson Air Force Base, Dayton, Ohio, for evaluation. The sample was confirmed by AFRL to be in compliance with all U.S. Air Force-prescribed alternative aviation fuel initial screening criteria.
\end{abstract}

This subtask was funded through the EERC-DOE Joint Program on Research and Development for Fossil Energy-Related Resources Cooperative Agreement No. DE-FC2608NT43291. Nonfederal funding was provided by Accelergy Corporation. 


\section{TABLE OF CONTENTS}

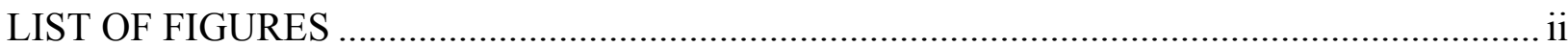

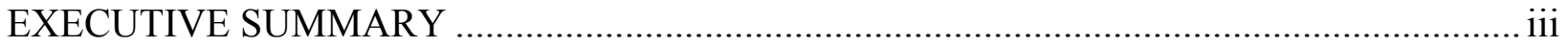

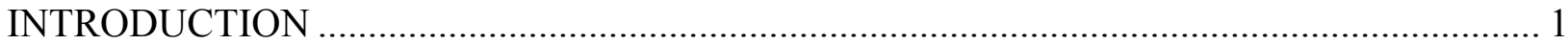

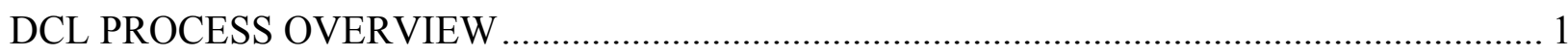

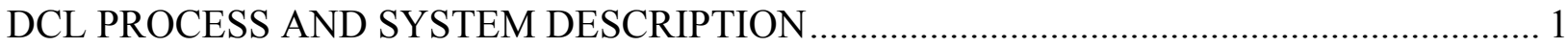

DCL SYSTEM DESIGN/FABRICATION TIME LINE ………......................................... 5

SHAKEDOWN OF OFF-LINE DISTILLATION SYSTEM..................................................... 8

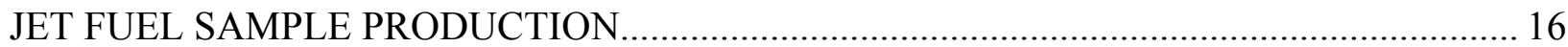

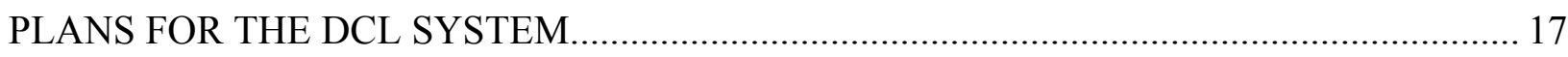

DCL SYSTEM HAZOP REVIEW STATUS AS OF 25 JULY 2012 ............................Appendix A DCL PROCESS DEVELOPMENT UNIT STANDARD OPERATING

PROCEDURE AS OF 25 JULY 2012 ....................................................................

COAL LIQUIDS DISTILLATION PROCEDURES AS OF 25 JULY 2012 ................Appendix C

PROCEDURES FOR BATCH DCL-BASED JET FUEL PRODUCTION....................Appendix D

DCL SYSTEM SHAKEDOWN PLANS …………….......................................... Appendix E 


\section{LIST OF FIGURES}

1 DCL process schematic illustrating unit operations and process streams........................ 3

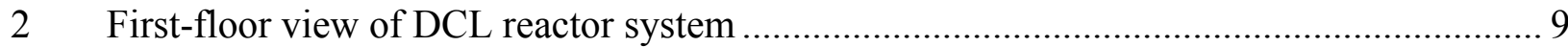

3 Close-up of DCL reactor sand bath ..................................................................... 10

4 Close-up of prereactor feed preparation and injection systems .................................... 11

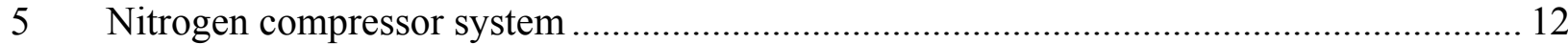

6 Second-floor view of DCL reactor system ....................................................... 13

$7 \quad$ Close-up of product separation and accumulation systems ....................................... 14

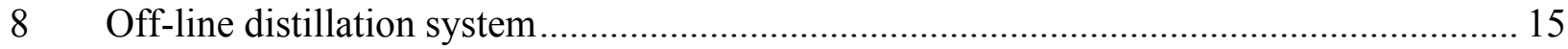

9 Schematic of 2-gallon batch autoclave system .................................................. 16

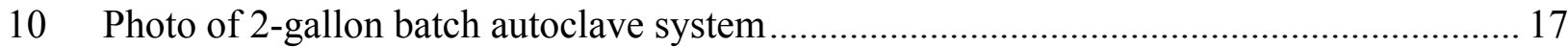




\section{SUBTASK 3.9 - DIRECT COAL LIQUEFACTION PROCESS DEVELOPMENT}

\section{EXECUTIVE SUMMARY}

The Energy and Environmental Research Center (EERC), in partnership with the U.S. Department of Energy (DOE) and Accelergy Corporation, an advanced fuels developer with technologies exclusively licensed from ExxonMobil, undertook Subtask 3.9 to design, build, and preliminarily operate a bench-scale direct coal liquefaction (DCL) system capable of converting pulverized, dried coal to a liquid suitable for upgrading to fuels and/or chemicals. The primary objectives of Subtask 3.9 were to:

- Finalize the design of a continuous-mode bench-scale DCL reactor system based on a preliminary design developed by the EERC and Accelergy.

- Construct and shake down the DCL reactor system.

- Use the DCL system to initiate production of a jet fuel derived from Illinois No. 6 coal, with the subsequent objective of submitting a sample of the jet fuel to the U.S. Air Force Research Laboratory (AFRL) at Wright-Patterson Air Force Base for analysis to assess compliance with key selected fuel property requirements cited in MIL-DTL-83133F, the U.S. military specification for JP-8 jet fuel.

Over the course of the approximate 30-month project, EERC design and engineering staff worked in partnership with Accelergy-provided design consultants on:

- Improving the overall DCL system design.

- Integrating the design into existing and project-developed EERC facilities and infrastructure.

- Assessing and developing strategies for mitigating the operational risks associated with the DCL system, which-because system operation necessitates the use of high pressure, high temperature, and hydrogen - were of critical importance to maximizing the safety of the operational staff.

At project initiation, the DCL system was slated for installation in an EERC building anticipated to be an ideal location based on a preliminary engineering estimate of the infrastructure improvements needed to support safe and efficient operation of the DCL system. Key needed improvements included ventilation, fire alarm, fire suppression, and gaseous exhaust combustion/flare systems. Because the actual total cost of making these improvements (based on qualified contractor bids received) was higher than the project budget could support, a new site was needed. Several options were evaluated, including skid-mounting the DCL system and temporarily installing it in a semi-outdoor location that would enable seasonal operation only, but none of the evaluated options offered the possibility of meeting fuel production deliverable objectives in accordance with project cosponsor Accelergy Corporation expectations. At the 
approximate 12-month point of the project, developments in nonrelated EERC projects led to an opening in the EERC National Center for Hydrogen Technology building, which is equipped with all necessary DCL project-required infrastructure, and tailoring of the DCL unit layout to accommodate this new space was initiated.

Although the site-selection problem resulted in the need to request a 10 -month no-cost project extension, activities associated with developing equipment specifications, soliciting bids for major equipment delivery, ordering system fabrication supplies and equipment, and fabrication of unit operations were ongoing and enabled maintaining project progress and focus throughout the time the DCL system was without a permanent installation site. Fabrication and installation of the DCL system and an accompanying distillation system (for off-line fractionation of raw coal liquids into a naphtha-middle distillate stream for upgrading and a recycle stream) was completed in May 2012. Shakedown of the system was initiated in July 2012. In addition to completing fabrication of the DCL system, the project also produced a 500-milliliter sample of jet fuel derived in part from direct liquefaction of Illinois No. 6 coal, and submitted the sample to AFRL for evaluation. The sample was confirmed by AFRL to be in compliance with all U.S. Air Force-prescribed MIL-DTL-83133F-derived alternative aviation fuel initial screening criteria.

This subtask was funded through the EERC-DOE Joint Program on Research and Development for Fossil Energy-Related Resources Cooperative Agreement No. DE-FC2608NT43291. Nonfederal funding was provided by Accelergy Corporation. 


\section{SUBTASK 3.9 - DIRECT COAL LIQUEFACTION PROCESS DEVELOPMENT}

\section{INTRODUCTION}

The Energy and Environmental Research Center (EERC), in partnership with the U.S. Department of Energy (DOE) and Accelergy Corporation, an advanced fuels developer with technologies exclusively licensed from ExxonMobil, undertook Subtask 3.9 to design, build, and preliminarily operate a bench-scale direct coal liquefaction (DCL) system capable of converting pulverized, dried coal to a liquid suitable for upgrading to fuels and/or chemicals. The primary objectives of Subtask 3.9 were to:

- Finalize the design of a continuous-mode bench-scale DCL reactor system based on a preliminary design developed by EERC and Accelergy.

- Construct and shake down the DCL reactor system.

- Use the DCL system to initiate production of a jet fuel derived from Illinois No. 6 coal, with the subsequent objective of submitting a sample of the jet fuel to the U.S. Air Force Research Laboratory (AFRL) at Wright-Patterson Air Force Base for analysis to assess compliance with key selected fuel property requirements cited in MIL-DTL83133F, the U.S. military specification for JP-8 jet fuel.

\section{PROCESS OVERVIEW}

DCL refers to a process by which coal is directly converted - via an essentially one-step process - to a liquid. Subsequent distillation and hydroprocessing is typically required to fractionate the raw liquid and convert its "naphtha-middle distillate" fraction to fuel and/or chemical products. DCL processes typically utilize ground (to about -100 mesh) and dried (to about $2 \%$ moisture content) coal and operate at temperatures and pressures of about $400^{\circ}-500^{\circ} \mathrm{C}$ and 2000-3000 psi, respectively, in the presence of hydrogen, solvent, and a liquefaction catalyst. A "start-up" solvent (typically a coal-derived creosote liquid or anthracene oil) is needed to initiate liquefaction. DCL process outputs include a gas product comprising about $10 \%$ of dried coal input and a raw liquid product comprising about $90 \%$ of dried coal input. The raw liquid product is distilled to yield naphtha and middle distillate products for hydroprocessingbased upgrading, a heavy oil for recycle, and a tar-like "vacuum bottoms" material (which includes unreacted and partially reacted coal, ash, and catalyst) for recycle.

\section{PROCESS AND SYSTEM DESCRIPTION}

The EERC-Accelergy DCL system is designed to process 45 pounds/day of coal. The system is installed on the first and second floors of the EERC National Center for Hydrogen Technology (NCHT) building, which is equipped with infrastructure necessary for safe and efficient operation including fire alarm and suppression systems and a hazardous gas alarm, 
ventilation system, gaseous emissions flare/combustion system, and nitrogen compressor. The intended uses of the DCL system are to 1) generally validate results of bench-scale batch-process DCL tests conducted to convert coal to liquids suitable for upgrading to jet and other transportation fuels, and 2) produce raw coal liquids for upgrading to large (up to 25-gallon) fuel samples for evaluation by AFRL. The DCL system is not intended to generate material balance or process scale-up data. The system will operate in a semicontinuous mode and comprises two primary subsystems:

1. The reactor system, comprising the primary process equipment needed to conduct liquefaction operations.

2. The off-line distillation system, installed in a large walk-in hood located in a laboratory near the reactor system. The distillation system is used to fractionally distill the raw coal liquids into a naphtha-middle distillate stream for upgrading (to finished fuel and/or chemical products) and a vacuum gas oil (VGO) solvent for recycle to the reactor system.

Figure 1 illustrates the key unit operations and input/output streams of the DCL process. In using the DCL system to produce a raw coal liquid sample from a target coal, initial processing is needed to prepare target coal-derived VGO and vacuum bottoms materials.

Vacuum bottoms material (referred to in Figure 1 as "bottoms") is generated in the main reactor system and VGO (referred to in Figure 1 as "recycle solvent") is recovered using the offline distillation system. For process initiation, a start-up slurry consisting of target coal, catalyst, and VGO derived from distillation of a procured coal tar will be premixed in a slurry mixing tank and then transferred to a slurry feed tank. The start-up slurry will then be fed into the tubular reactor at a predetermined rate. The resulting slurry product will be stripped to remove volatile products. The volatile products will be condensed to form liquid using a series of condensers, and remaining slurry (vacuum bottoms) will be collected and transferred to a freezer for storage. The condensed raw coal liquids that are collected (on a 6-hour basis) will be transferred to the off-line distillation system and distilled to yield about 4.2 liters of VGO and 3 liters of distillate comprising naphtha, water, and a "middle distillate cut" (which will necessarily contain a significant amount of start-up slurry-derived coal tar distillate). The VGO obtained from distillation (along with the previously collected vacuum bottoms) will be used for recycle. The purpose of the initial processing is to generate enough target coal-derived vacuum bottoms and VGO to start the liquefaction process with $100 \%$ target coal-derived inputs, after which the process will be self-sustaining in production of $100 \%$ target coal-derived raw liquids. After sufficient amounts of vacuum bottoms and VGO needed to initiate the liquefaction process are produced, further processing will be conducted to produce target coal-derived middle distillate for upgrading to jet fuel or other fuels. Middle distillate upgrading will be conducted in a separate EERC hydroprocessing facility.

The liquefaction process will utilize predried ( $1 \%-2 \%$ moisture) coal and vacuum bottoms, both ground to -100 -mesh-size particles. During sample production liquefaction operations, coal, vacuum bottoms, VGO, and catalyst will be fed to the slurry tank. The overall process involves feeding slurry consisting of an approximate 1/1/1 mixture of coal (2 pounds [lb]), coal- 


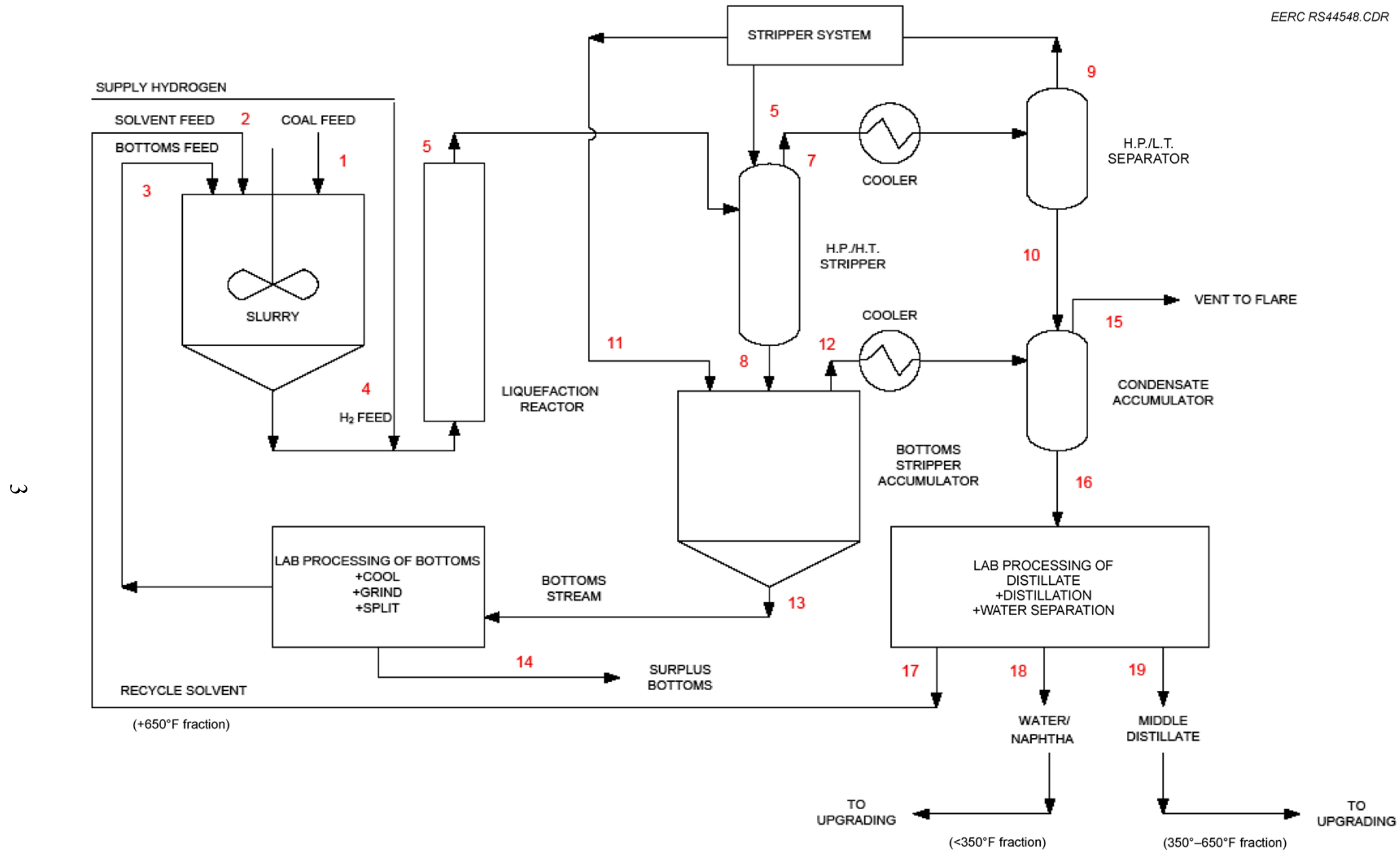

Figure 1. DCL process schematic illustrating unit operations and process streams. 
derived VGO solvent $(1.8 \mathrm{lb})$, vacuum bottoms $(1.8 \mathrm{lb})$ and 100-300 parts per million (ppm) catalyst per hour through a tubular reactor system heated in a fluidized sand bath. A constant pressure of 2500 psi will be maintained through use of a pressure control valve and constant flow of hydrogen. Standard DCL system operating conditions are:

- Temperature $-450^{\circ} \mathrm{C}$

- Pressure - 2500 psi

- Residence time - 60 minutes

These operating conditions can be varied depending on the composition and reactivity of the material that will be processed. However, the maximum allowable temperature and pressure for the system are $500^{\circ} \mathrm{C}$ and $2500 \mathrm{psig}$, respectively. The desired operating temperature can be maintained with automated controls. The 60-minute residence time is based on a 2-liter/hour $(\mathrm{L} / \mathrm{hr})$ flow rate with six 43-inch-long reactor tubes installed. This residence time can be changed by either adding or subtracting tubes or by changing the overall flow rate of the system. The pressure of the system is also variable if needed and could be increased to up to $2750 \mathrm{psig}$. The DCL process will use $2 \mathrm{lb}$ of predried coal an hour. The solvent VGO and vacuum bottoms will be recycled. The amounts and compositions of the products will be dependent on the coal used. The DCL system will produce the following products:

1. Gases: The gas yield will be about $0.15 \mathrm{lb} / \mathrm{hr}$ or $8 \mathrm{wt} \%$ of dry ash-free (daf) coal. The gases produced will include $\mathrm{H}_{2}, \mathrm{H}_{2} \mathrm{~S}, \mathrm{NH}_{3}, \mathrm{CO}, \mathrm{CO}_{2}$, methane, ethane, propane, and butane. The gases will be passed through a scrubber to remove corrosives, and the scrubbed gases will be routed to a flare system for destruction.

2. Liquids: Two types of liquids — primarily aqueous and organic (oils) will be produced by the DCL system:

- Aqueous products $(0.18 \mathrm{lb} / \mathrm{hr}$ or $10 \mathrm{wt} \%$ of daf coal added): This fraction will contain small amounts of alcohols, ketones, phenols, mercaptans, and hydrocarbons dissolved in water. Therefore, wastewaters are potential hazards and need to be disposed of according to U.S. Environmental Protection Agency guidelines.

- Oils: Oils will be taken to a semiautomatic off-line distillation system for fractional distillation to produce the following fractions:

- Naphtha (room temperature to $350^{\circ} \mathrm{F} ; 0.15 \mathrm{lb} / \mathrm{hr}$ or $8 \mathrm{wt} \%$ of daf coal used) to be reformed or upgraded to produce a gasoline blendstock or chemical feedstock.

- Middle distillate $\left(350^{\circ}-650^{\circ} \mathrm{F} ; 0.78 \mathrm{lb} / \mathrm{hr}\right.$ or $44 \mathrm{wt} \%$ of the daf coal added) to be upgraded to produce jet and/or diesel fuels.

- Heavy oil $\left(>650^{\circ} \mathrm{F}\right)$ to be recycled. 
Oil distillates will be stored in a freezer until they are ready for upgrading to finished fuels. The finished fuels will be packaged under nitrogen and stored in a freezer.

- Solids (30 wt $\%$ of the daf coal added): The amount of vacuum bottoms produced is expected to be $0.54 \mathrm{lb} / \mathrm{hr}$. Since the ash contained in the coal will also appear in the vacuum bottoms, the actual total amount of bottoms is expected to be 0.75 pounds an hour. The tarlike vacuum bottoms product, which comprises the residue remaining after stripping of the liquefaction slurry (with a boiling point of $>1000^{\circ} \mathrm{F}$ ), will be recycled. The solids will be stored in a freezer until recycled.

In summary, the liquefaction slurry produced by the DCL unit will be continuously stripped to drive off most of the volatiles. The remaining slurry will be continuously siphoned off as tar and collected in collection vessels and stored in a freezer. The frozen bottoms will be pulverized to -100 -mesh size and transferred into the mixing tank for recycle. The volatile products will be carried through a series of condensers and the condensate (distillate) will be collected in collection vessels for transfer to the off-line distillation system. The condensate will be periodically batch-distilled to recover the VGO for transfer to the slurry mix tank and recycle. Naphtha and middle distillate will be stored in a freezer prior to undergoing off-line upgrading and/or other processing. The uncondensed gases will be sent to a flare system for combustive destruction. The gaseous, liquid, and solid products formed during liquefaction are potentially hazardous and must be handled, stored, and disposed of according to published city and state regulations. All personnel designated to handle these products will be appropriately trained. The DCL system will be equipped with an emergency medical kit, eye wash stations, and a safety shower.

\section{SYSTEM DESIGN/FABRICATION TIME LINE}

The EERC DCL system concept and initial design (comprising a preliminary process flow diagram, process stream descriptions, and overall material balance) were developed in collaboration with Accelergy prior to initiation of Subtask 3.9. Initial Subtask 3.9 activities focused on DCL design completion and improvement, and definitively establishing the magnitude and cost of EERC infrastructure improvements required to ensure safe and efficient DCL system operation. As the subtask progressed, work emphasis shifted to procurement of equipment and supplies and fabrication of individual unit operations in preparation for their insertion into an integrated system. Although the subtask experienced an unanticipated and schedule-impacting change in installation location because of higher-than-projected infrastructure improvement costs for the originally selected location, the ability to maintain unit operation design and fabrication activities throughout this challenge enabled a minimal impact on project cost, and fabrication and installation of the DCL system (and accompanying off-line distillation system) were completed within budget. Subtask activities were carried out over the period of April 2010 to May 2012. Key milestones achieved during each quarter of the 26-month effort are described below. 


\section{April-June 2010}

- The DCL system design was significantly improved by incorporation of a unit operation that enables online stripping of volatiles from raw DCL coal liquids, thereby reducing off-line distillation requirements.

- Size and performance specifications and bid requests for major DCL equipment pieces were developed.

\section{July-September 2010}

- All major equipment pieces and fabrication supplies for the DCL reactor and ancillary systems were ordered.

- Based on a detailed engineering assessment conducted in collaboration with a qualified and highly recommended commercial architectural and engineering firm, specifications were developed for the infrastructure improvements needed to support DCL system operation in the originally selected EERC location, and bid requests for making the improvements were provided to qualified contractors.

\section{October-December 2010}

- Contractor bids for making the structural, mechanical, and electrical improvements required for installation of the DCL reactor system in the originally selected EERC location were received and reviewed. The bids showed that the total cost of making the necessary improvements was significantly higher than estimated. Because the cost was also significantly beyond what the project budget could support, a decision was made to evaluate alternative locations for installation of the DCL system.

\section{January-March 2011}

- Based on an evaluation of alternative locations for installing the DCL system, a decision was made to skid-mount the system, with the goal of eventually moving it into a new building being constructed at the EERC. Skid-mounting was deemed the best solution at this time, since it would enable completion of system fabrication and possible seasonal (MaySeptember) operation of the system in a semioutdoor location, if operation was needed prior to completion of the new building.

- An improved set of DCL system process and instrumentation drawings (P\&IDs) was prepared based on a breakdown of the overall system into the four major process areas described below:

- Area 100 - gas supply and delivery

- Area 200 - feed slurry and solvent preparation and delivery

- Area 300 - preheaters, sand bath heater, and reactors

- Area 400 - product separation and collection vessels and product gas cleanup and recycle system 


\section{April-June 2011}

- Because of unexpected developments in projects ongoing in the NCHT building, a two-level site in the NCHT building was secured for permanent installation of the DCL reactor system. The NCHT site is equipped with the fire alarm, fire suppression, ventilation, and gaseous emission combustion/flare systems needed for safe and efficient DCL system installation and operation.

- A two-level layout for the DCL system was developed, and system installation in the NCHT building was initiated.

- The EERC worked closely with an Accelergy-retained consultant team to help expedite the transition of the DCL system design from a skid-mounted to a permanent installation design and to help ensure that the design will translate to a safe, efficient, and easily operable and maintainable DCL system. Key activities included detailed review and modification-as recommended by the Accelergy team - of P\&IDs, equipment specification lists, and process flow diagrams. Because of the design and layout adjustment required in transitioning from a skid-mounted to a permanently installed DCL system configuration, a no-cost project schedule extension request was made to the DOE. The request was graciously granted.

\section{July-September 2011}

- The 2-level DCL system layout for installation in the NCHT building was finalized, as were a complete set of P\&IDs based on the new system layout.

- With on-site assistance from Accelergy-retained consultants, a comprehensive hazardous operations (HAZOP) assessment of the overall DCL reactor system was conducted. The assessment included the off-line batch distillation system that will be used to separate raw coal liquids into product and recycle streams. Nine EERC staff and two Accelergy-retained consultants participated in the assessment. Many DCL system safety and operability concerns were raised and discussed. Appendix A comprises a list of action items generated as a result of the HAZOP assessment and includes a description of steps taken to address safety and operability issues. Appendix A also contains a list of valve failure response actions. Two major concerns that came out of the HAZOP are described below:

1. The DCL system hydrogen compressor was originally sited almost directly below the reactor system, which represented an unacceptably high risk of ignition/explosion of hydrogen (from a possible compressor leak) by its potential contact with hot reactor system surfaces. This issue was resolved by eliminating the hydrogen compressor and replacing it with a remotely sited high-pressure hydrogen supply.

2. A thermal oxidizer (utilized by several EERC gasification projects ongoing in the NCHT building) was sited sufficiently close to the DCL reactor system to represent an unacceptably high hydrogen ignition/explosion risk because of the potential for possibly leaking hydrogen (from the reactor system) to contact an exposed hot surface of the thermal oxidizer. This issue was resolved by instituting a policy that calls for turning off the thermal oxidizer and cutting off (and locking out access to) its natural gas fuel supply during all DCL system runs. 


\section{October-December 2011}

- The bid process for selecting the automated off-line distillation system needed for raw coal liquids fractionation and the upgrading of product fractions was completed, and a system was selected and ordered.

- Arrangements were made with the Stella-Jones Corporation to deliver to the EERC (by February 2012) a coal-derived solvent, RT-12, for use as a DCL system start-up solvent.

- Preparation of a comprehensive DCL system operations manual and a procedural manual for conducting the fractional distillation of raw coal liquids into recycle and product streams was initiated.

\section{January-March 2012}

- A DCL system operations manual and a distillation procedures manual were completed; copies are provided as Appendixes B and C, respectively.

\section{April-June 2012}

- Fabrication and installation of the DCL reactor system was completed. Figures 2-7 are photographs of the installed system.

- Fabrication and installation of the off-line distillation system was completed. Figure 8 is a photograph of the installed system.

\section{SHAKEDOWN OF OFF-LINE DISTILLATION SYSTEM}

Although the DCL system is designed to enable continuous-mode operation, it is not equipped with an online distillation capability for real-time fractionation of raw coal liquids into product and recycle streams. This means that the raw coal liquids must be recovered and removed from the DCL, manually transferred to an off-line batch distillation system, and fractionated into product and recycle streams, after which the product stream (naphtha plus middle distillate) is transferred to an upgrading process for conversion to fuel and/or chemical products, and the recycle fraction VGO is transferred back to the DCL system for recycle. It is anticipated that approximately 1 liter of VGO an hour will be needed to sustain continuous operation of the DCL system. Shakedown of the newly installed distillation system was performed using two surrogate solutions: one representative of raw coal liquids and one representative of a middle distillate upgrading product from which diesel, jet fuel, and naphtha products could be distilled. The objective of the shakedown was to optimize the heat input rate needed to attain the shortest-duration distillation time required to fractionate the raw coal liquid or fuel-grade mixture into the desired distillation cuts. Details of the shakedown are as follows:

1. Shakedown with surrogate raw coal liquids - A 6-liter sample of raw coal liquids surrogate was prepared by mixing 8 vol\% water with 8,30 , and 54 vol $\%$ of previously produced coal liquids boiling in the naphtha $\left(<300^{\circ} \mathrm{F}\right)$, middle distillate $\left(300^{\circ}-600^{\circ} \mathrm{F}\right)$ and vacuum gas oil $\left(600^{\circ}-1000^{\circ} \mathrm{F}\right)$ ranges, respectively. The distillation was repeated 
several times by using spinning band and packed columns to define the operating conditions that will yield the following fractions/distillation cuts:

- Light (naphtha) fraction $\left(<300^{\circ} \mathrm{F}\right)$

- Middle distillate fraction $\left(300^{\circ}-600^{\circ} \mathrm{F}\right)$

- Heavy VGO fraction $\left(>600^{\circ} \mathrm{F}\right)$

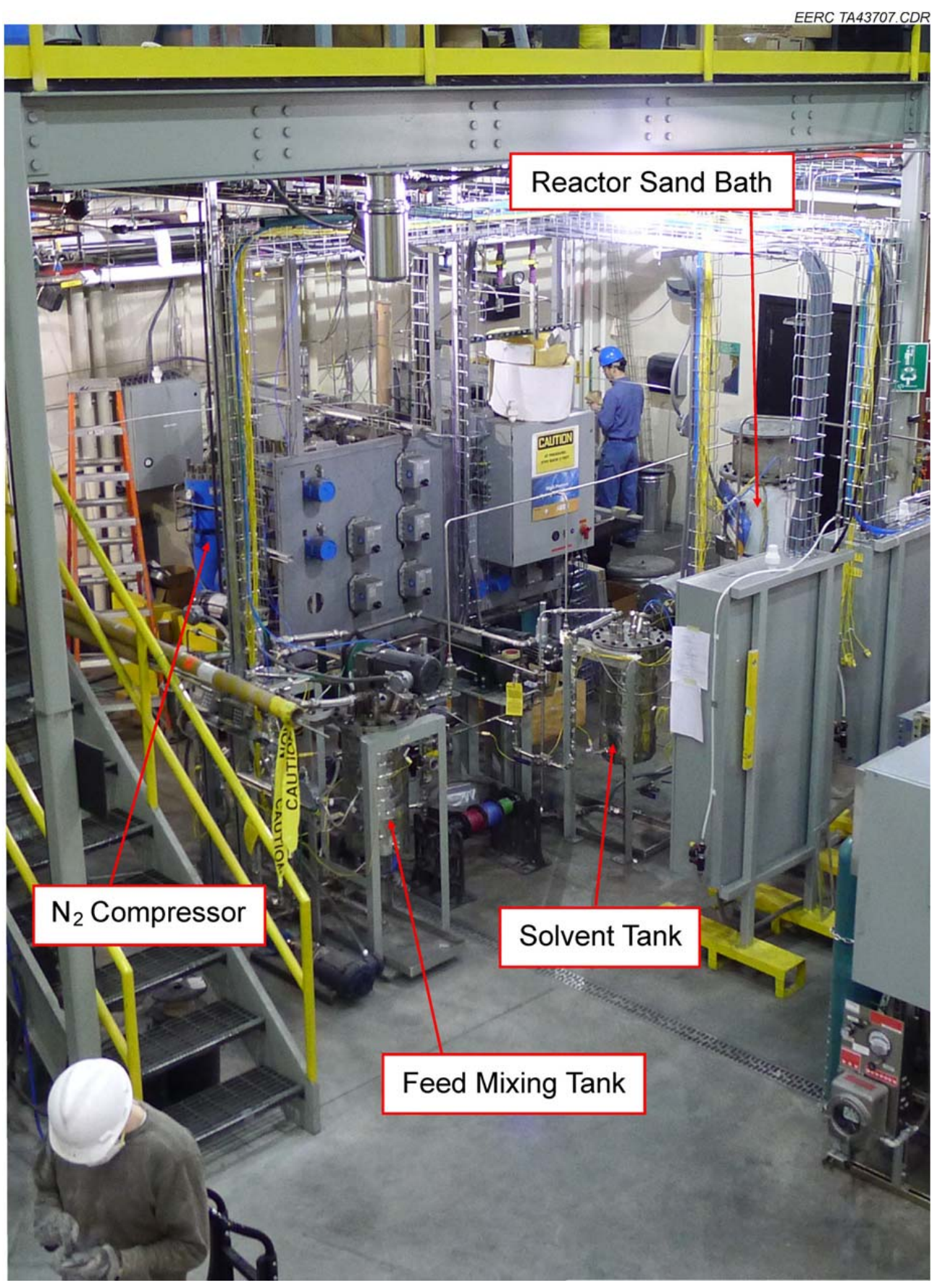

Figure 2. First-floor view of DCL reactor system. 


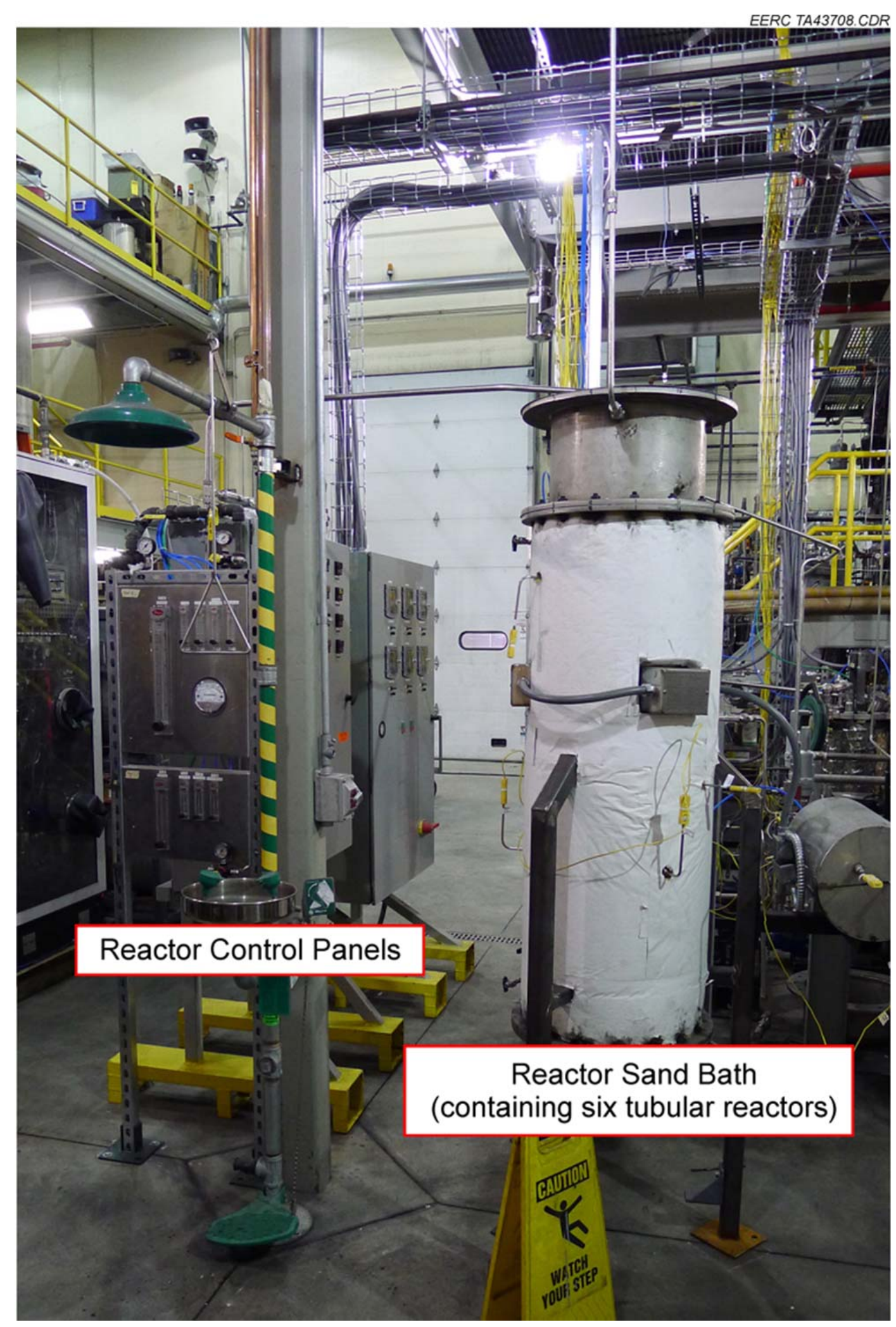

Figure 3. Close-up of DCL reactor sand bath. 


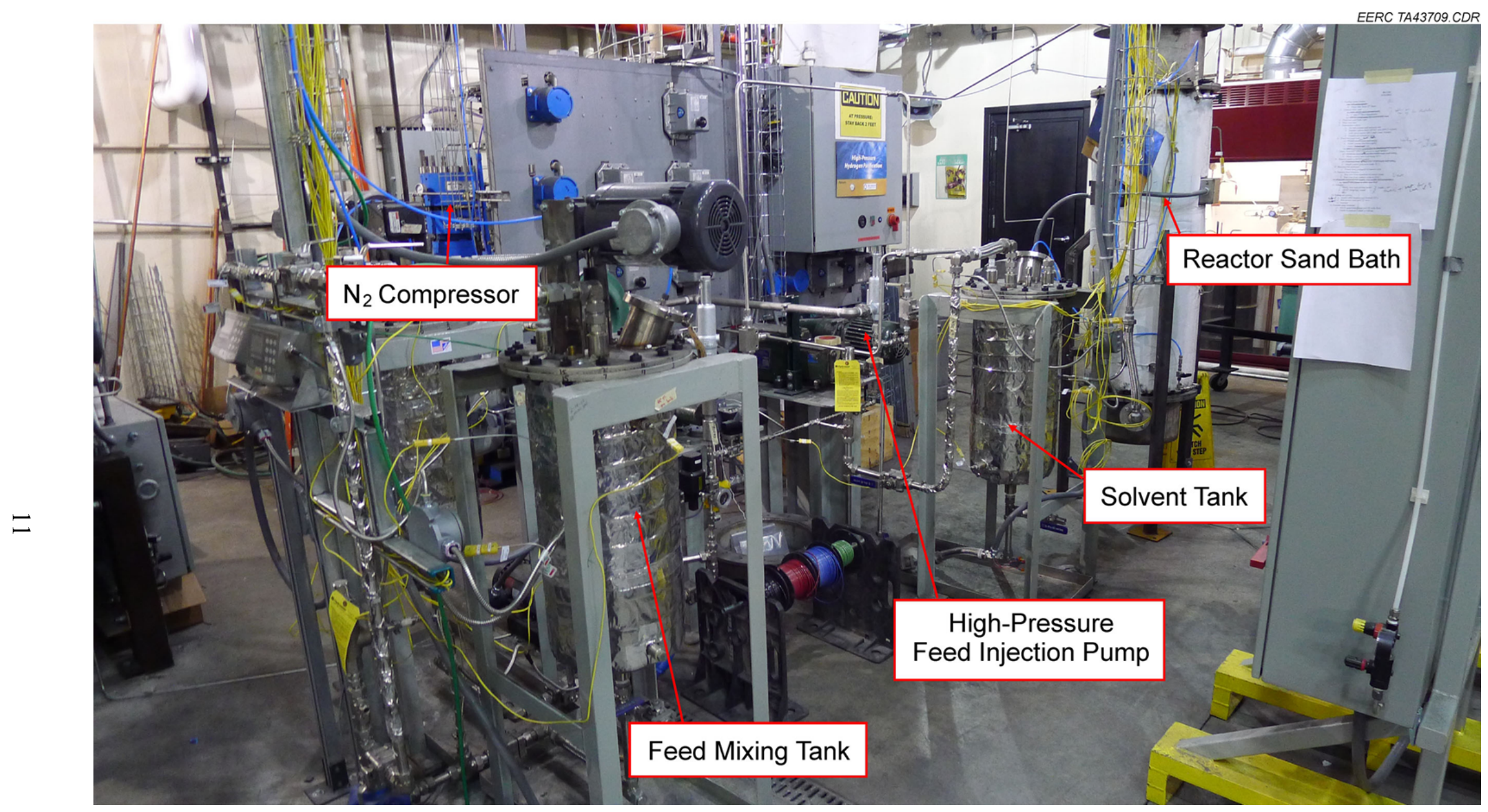

Figure 4. Close-up of prereactor feed preparation and injection systems. 


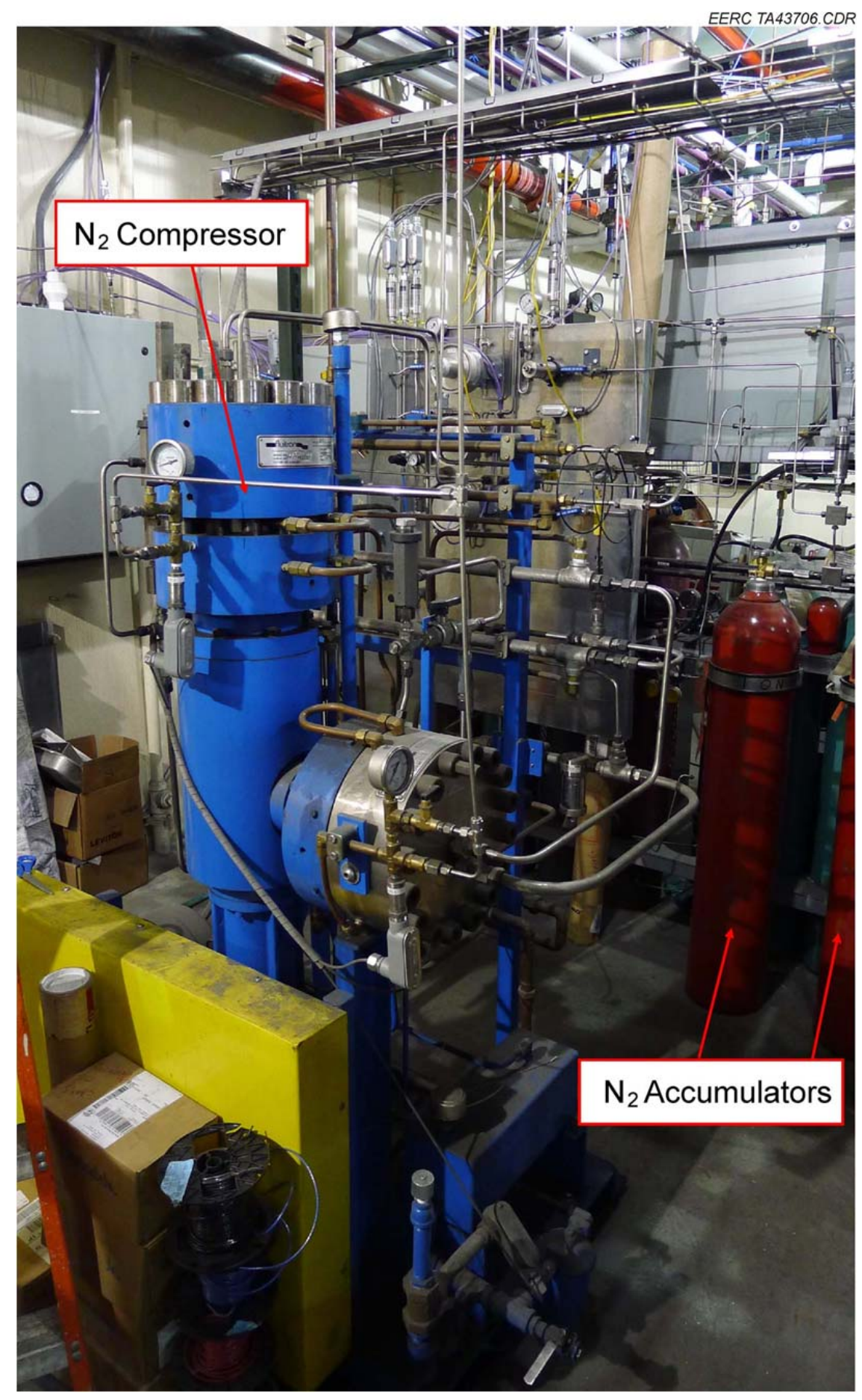

Figure 5. Nitrogen compressor system. 


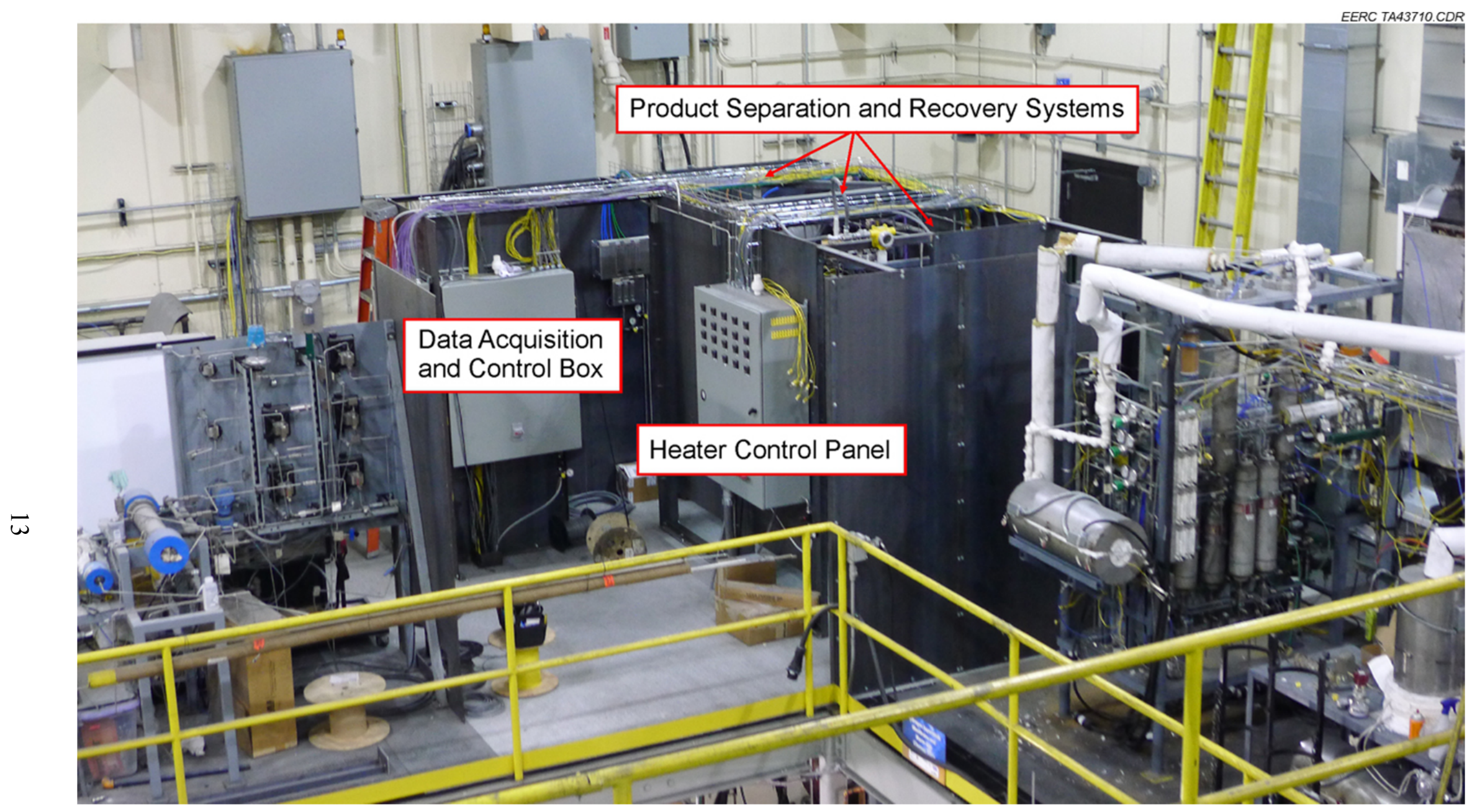

Figure 6. Second-floor view of DCL reactor system. 


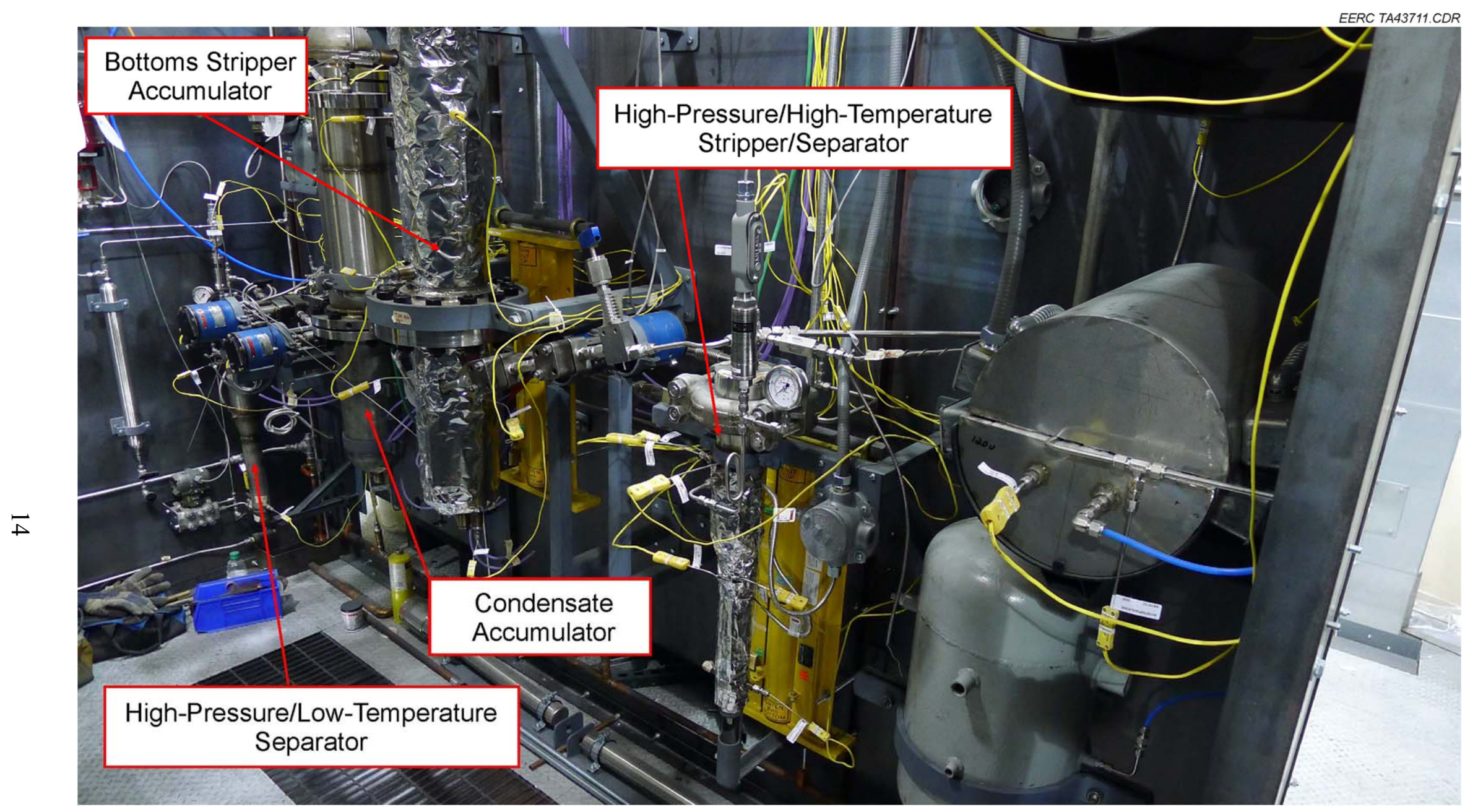

Figure 7. Close-up of product separation and accumulation systems. 


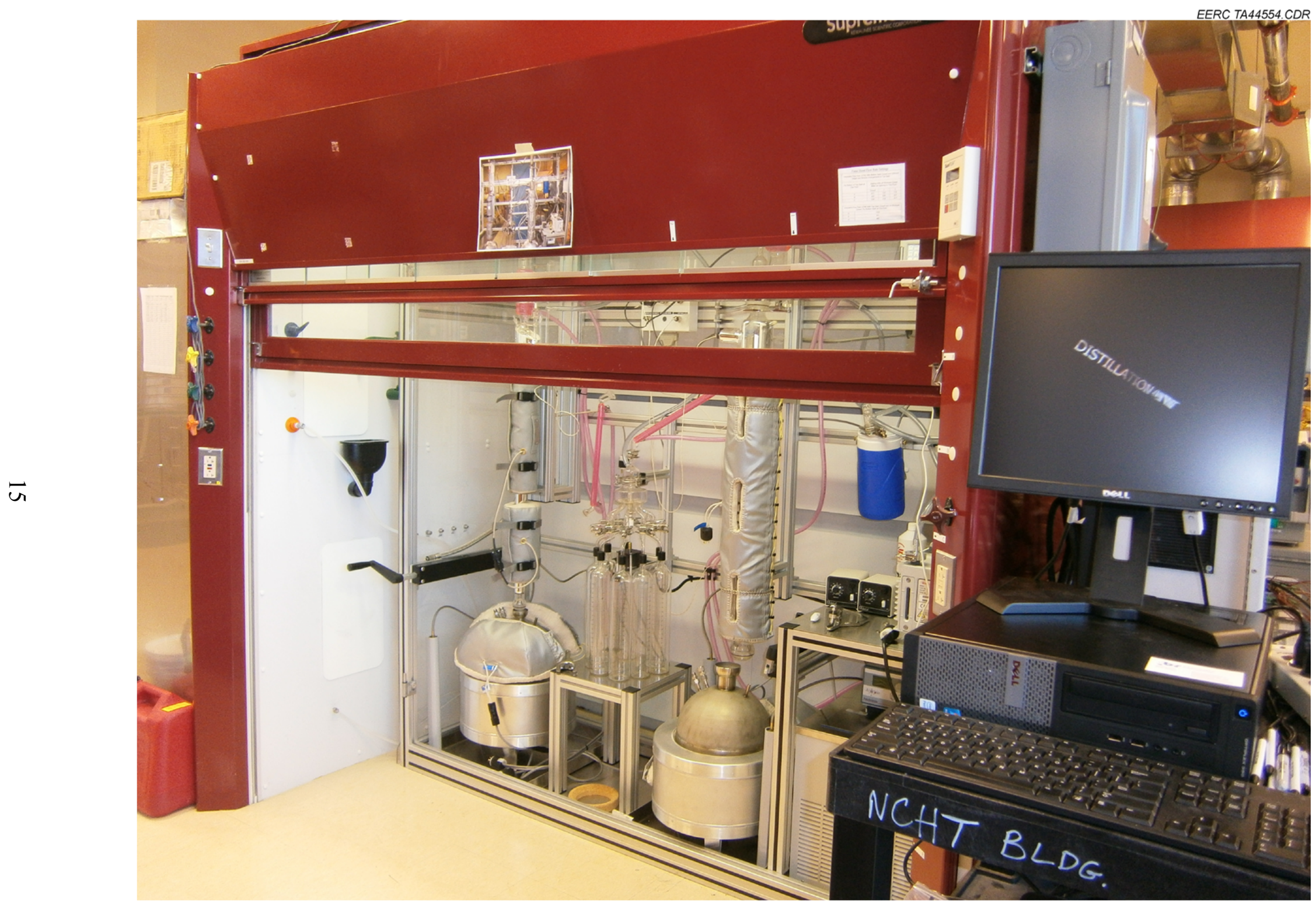

Figure 8. Off-line distillation system. 
2. Shakedown with surrogate middle distillate upgrading product - A 6-liter mixture of normal paraffins, isoparaffins, cycloparaffins, and aromatics representative of a likely middle distillate upgrading product was prepared. The mixture comprised about $2 \mathrm{vol} \%$ water, 5 vol\% naphtha, 63 vol\% commercial jet fuel, and 30\% diesel fuel. As before, the distillation was repeated several times by using spinning band and packed columns to define the operating conditions that will yield the following distillation cuts:

- Naphtha fraction $\left(<300^{\circ} \mathrm{F}\right)$

- Jet fraction $\left(300^{\circ}-500^{\circ} \mathrm{F}\right)$

- Diesel fraction $\left(>500^{\circ} \mathrm{F}\right)$

\section{JET FUEL SAMPLE PRODUCTION}

In order to provide a 500-milliliter coal-derived jet fuel sample to AFRL for evaluation prior to completion of DCL system fabrication, a batch autoclave coal liquefaction system was utilized to convert Illinois No. 6 coal to a raw coal liquid, which was then distilled to yield a middle distillate cut that was upgraded (via hydroprocessing) to a jet fuel blendstock. Figures 9 and 10 are a schematic and photo, respectively, of the batch autoclave system used to produce the raw coal liquids. Appendix D describes the procedures used to produce the coal-derived jet fuel blendstock. Because the U.S. Air Force has been directed to evaluate options for accessing petroleum-alternative fuels with carbon footprints that are equal to or smaller than those of petroleum-derived fuels, a decision was made to mix the coal-derived cycloparaffin-rich and aromatics-containing jet fuel blendstock with an isoparaffin-rich and normal paraffin-containing jet fuel blendstock generated via hydroprocessing of canola oil, at a blend ratio of $60 \%$ coalderived material $-40 \%$ renewable oil-derived material. The resulting sample was delivered to AFRL, where it was analyzed and found to comply with all AFRL JP-8 jet fuel screening criteria.

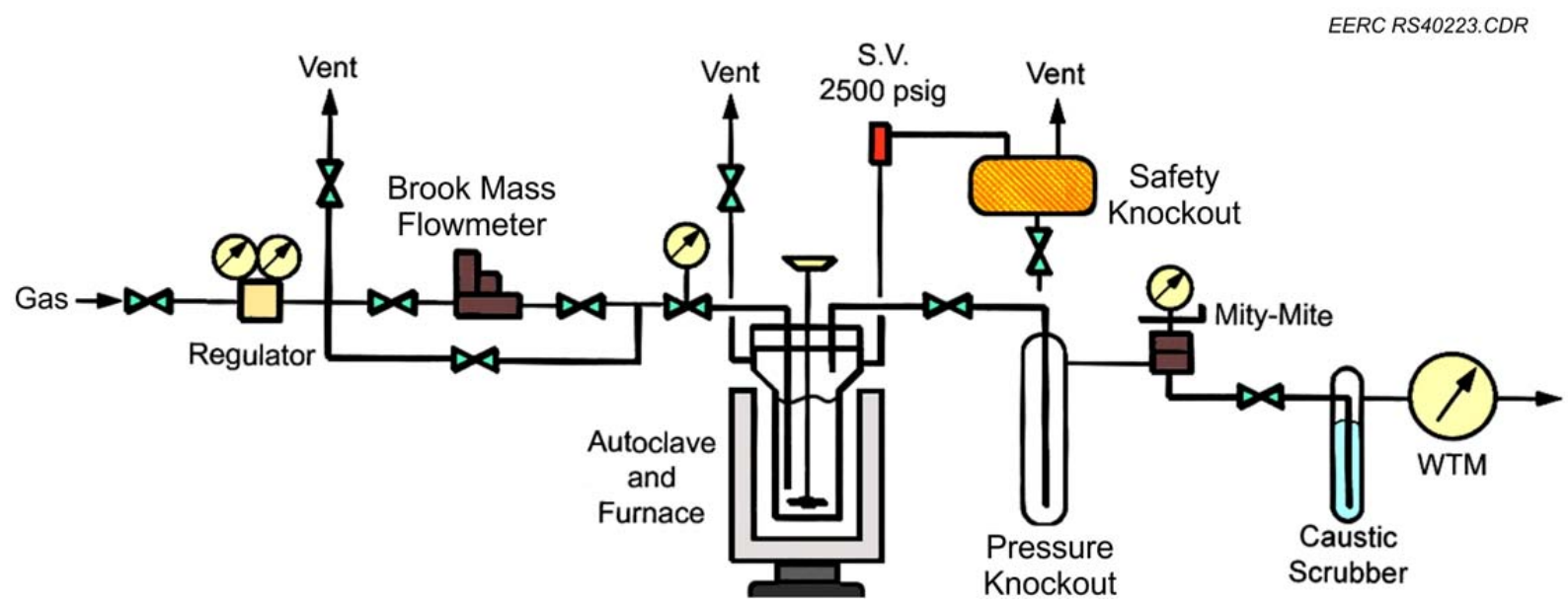

Figure 9. Schematic of 2-gallon batch autoclave system. 

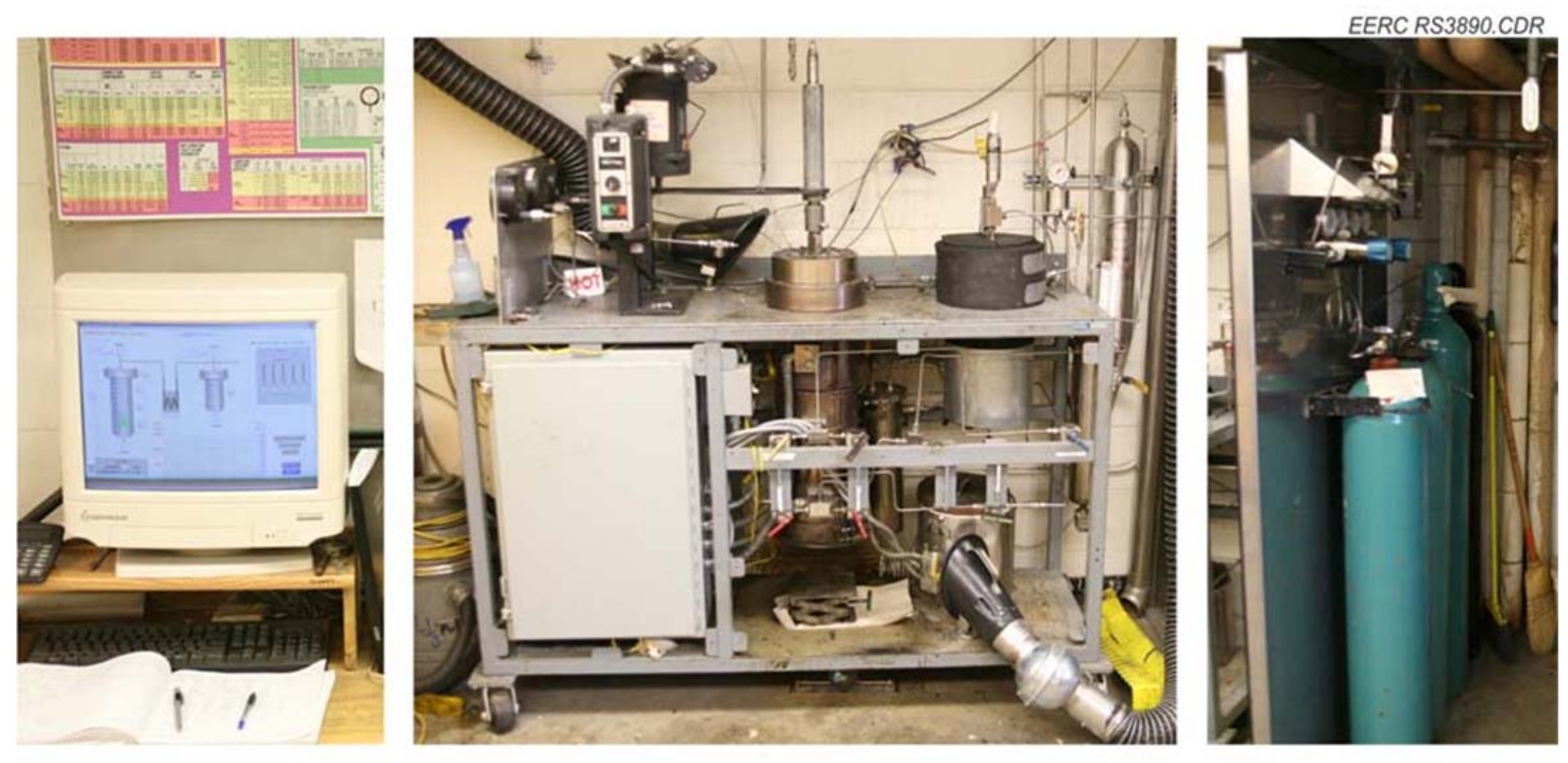

Figure 10. Photo of 2-gallon batch autoclave system.

\section{PLANS FOR THE DCL SYSTEM}

DCL system shakedown activities were initiated in the second half of July 2012 (see Appendix E for an overview of shakedown procedures), after which plans call for validation of DCL system performance by using the system to generate at least 1 liter of steady-state-produced raw coal liquids from Illinois No. 6 coal. System performance will be validated if the coal throughput achieved and the chemical and physical properties of the raw coal liquids generated match those achieved and generated in Exxon-conducted DCL tests with Illinois No. 6 coal (the data for which are in the possession of Accelergy). Following validation with Illinois No. 6, the DCL system will be used to generate raw coal liquids from a Montana subbituminous coal in sufficient quantity to yield 2 liters of middle distillate for upgrading to a jet fuel sample, which will be delivered to AFRL for evaluation. Plans then call for use of the DCL system to produce several gallons of lignite coal-derived raw coal liquids, which will be delivered to an oil refinery for evaluation as a refinery input. The order of these three process operations (bituminous coal first, followed by subbituminous, then lignite) is necessary to ensure the best potential for successful operation with each coal, because Exxon/Accelergy experience has shown that bituminous coals are easiest to process, subbituminous coals are somewhat more challenging, and lignites are most difficult. 


\section{APPENDIX A}

\section{SYSTEM HAZOP REVIEW STATUS AS OF 25 JULY 2012}




\section{NOMENCLATURE}

\begin{tabular}{|c|c|}
\hline ALARA & as low as reasonably achievable \\
\hline ATC & air-to-close \\
\hline ATO & air-to-open \\
\hline AV & automated valve \\
\hline BSA & bottoms stripper accumulator \\
\hline CA & condensate accumulator \\
\hline $\mathrm{CV}$ & check valve \\
\hline DAQ & data acquisition \\
\hline DCL & direct coal liquefaction \\
\hline DOT & Department of Transportation \\
\hline EERC & Energy \& Environmental Research Center \\
\hline ESA & electrical swing adsorption \\
\hline FCV & fuel cell vehicle \\
\hline FB & fluid-bed \\
\hline FIC & flow indicator/controller \\
\hline HP & high-pressure \\
\hline $\mathrm{HP} / \mathrm{HT}$ & high-pressure/high-temperature \\
\hline $\mathrm{HP} / \mathrm{LT}$ & high-pressure/low-temperature \\
\hline $\mathrm{HV}$ & hand valve \\
\hline HX & heat exchanger \\
\hline LIC & level indicator/controller \\
\hline LP & low pressure \\
\hline MAWP & maximum allowable working pressure \\
\hline MFC & mass flow controller \\
\hline MOP & maximum operating pressure \\
\hline MSDS & material safety data sheet \\
\hline MV & manual valve \\
\hline MWP & maximum working pressure \\
\hline NCHT & National Center for Hydrogen Technology \\
\hline OD & optical density \\
\hline PC & pulverized coal \\
\hline P\&ID & piping and instrumentation diagrams \\
\hline $\mathrm{PIR} / \mathrm{PI}$ & pressure indicator recorder/pressure indicator \\
\hline PPE & personal protection equipment \\
\hline PSV & pressure safety valve \\
\hline PVC & pressure valve control \\
\hline RV & relief valve \\
\hline SOP & standard operating procedure \\
\hline SP & set point \\
\hline TC & thermocouple \\
\hline TEFC & totally enclosed fan cooled \\
\hline UND & University of North Dakota \\
\hline VFD & variable frequency drives \\
\hline VFO & variable frequency oscillator \\
\hline
\end{tabular}




\section{SYSTEM HAZOP REVIEW STATUS AS OF 25 JULY 2012}

\section{9/13/11 Action Items Area 100H}

- Disconnect gas analyzer from $\mathrm{H}_{2}$ comp.

- Drain on bottom of vent line - stack pipe in pipe.

- Decide on $\mathrm{H}_{2}$ accumulator location.

- Determine location of $\mathrm{H}_{2}$ six-pack - review criteria.

- Label exactly how $\mathrm{H}_{2}$ connects to DCL system - verify safety valves RV-6 RV-7.

- Add relief pressures on P\&IDs.

- Shutdown/start-up and operating logic to P\&ID.

- Possibly add all details on compressor such as manufacturer maintenance procedure.

- Volume release of $\mathrm{H}_{2}$ and/or $\mathrm{H}_{2}$ accumulation.

\section{9/13/11 Area 100N Action Items}

- Verify all electrical classification.

- Hydro test accumulators or pressure test according to DOT testing.

- Verify how we do all of our reliefs; can’t use thermal oxidizer as a safety device.

\section{9/13/11 Area 100 Action Items}

- Develop drawing showing how MFC will be implemented.

- SOP needs to address what we will do in case of loss of house $\mathrm{N}_{2}$ to our purge for control boxes.

- Delete burst pressure from drawing legend; change MWP to MOP or MAWP.

- Add another check valve after CV-114.

- Decide whether or not we need to double valve or add a bleed line on PIR/PI isolation valves.

- Possibly put seal on all valves to purged vent valve safety valves - PSV-104 and PSV-112.

- Evaluate possible $\mathrm{N}_{2}$ leak and raising $\mathrm{N}_{2}$ level in vicinity.

\section{9/13/11 Area 200}

- Change slurry mix tank temperature to $300^{\circ} \mathrm{F}$.

- Determine operating pressure of product tanks - would be advisable to be 50 psi.

- Add $\mathrm{N}_{2}$ purge to all tank vents lines/blanket tanks.

- Add that the Viking pumps have VFDs.

- Check to see if we can get Group B motors that are VFO rated.

- Verify that the motors have no arcing or sparking.

- Possibly provide a flush option for Viking pumps.

- Add flow direction on cooling water on each tank condenser (change valves to rotometers).

- Consider adding external relief on the three Viking gear pumps or see if we can remove and check the internal reliefs.

- If possible, display more detail such as flex connection, show scales. 
- Add all design temps and press on P\&IDs.

- Address coal moisture in the process.

\section{9/13/11 Area 300}

- Slurry preheater - need to edit and change description.

- Change where we mix the $\mathrm{H}_{2}$ with the slurry before the sand bath- possibly before preheat.

- Possibly move or eliminate PSV302 because of the change in the $\mathrm{H}_{2}$ addition - need to discuss this design change - all reactor components designed higher than everything else.

- Determine the appropriate location for the sand bathheater (add TC) in exit pipe/determine proper size of exit.

- Put air usage of sand bath on P\&ID.

- Change sand bath to $\mathrm{N}_{2}$ instead of air for fluidization.

- Low-flow switch that will turn off heaters in sandbath.

- Verify proper labeling of MV-304 and FIC-302.

- Check all check valve symbols and make sure they are correct.

- Consider changing our manifold design using sintered metal thimbles.

\section{9/13/11 Area 400 High Pressure/400 Low Pressure Combined}

- Review need for reliefs on vessels in 400 HP P\&ID.

- Heat exchangers - sublimation of ammonia and chlorides need to have a capability for water injection at the front of HX-406.

- Evaluate potential for $\mathrm{H}_{2}$ embrittlement in HX-406 and HX-408.

- Consider switching our sulfur scrubbers to 400 low pressure after condensate accumulator before thermal oxidizer.

- Develop a procedure for operating with our nuclear sources open.

- Wayne suggests we eliminate Valve 406 on 400LP and put AV-410 as close as possible to bottom of bottoms stripper accumulator.

- Look at process of grinding bottoms.

\section{9/14/11 Risk Assessment Process}

- Comments by Wayne and Dick (Accelergy consultants) about layout confined space operators in the immediate area layout - is there enough room for maintenance and operator routine activities.

- $\mathrm{H}_{2}$ compressor - they would like it moved.

- Dick: Move the compressor - concerned with the location of the thermal oxidizer, concerned with its system operations - he is also concerned with our electrical equip. classification.

- Evaluate location of compressor.

- Evaluate partitions - work space.

- Adequate ventilation?

- Reevaluate flame jet ignition - flow restrictions.

- Add drip-pans and liquid containment. 
- Evaluate potential of light gases being trapped under solid floor decking.

- Evaluate benefits of using $\mathrm{H}_{2}$ six-packs only and no $\mathrm{H}_{2}$ compressor.

\section{9/14/11 Risk Assessment Cont. New Action Items Area 100}

- Dick's comments:

- 100 - Add valve failure action as a component, such as what happens with loss of air pressure.

- Evaluate whether we should add an E-stop or use a surge flow device to control automated shutoff.

- Shutdown matrix - needs to be developed.

- Wayne would like us to add a tubing fitting failure section.

- Dick also thinks fitting failure also needs to be addressed for possible under pressure for large leak: how do we address it - safety valve - flow restriction; use check valves in every possible situation that we can.

\section{9/14/11 Area 200 Comments Action Items}

- Could add a rupture disc before safety relief valve on HP pumps.

\section{Area 300 Comments Action Items}

- Mike Collings concerned about our temp of $\mathrm{H}_{2}$ preheaters - incorporate a low-flow cut off on the heaters (preheaters).

- How we will deal with plugged lines.

- Separate stack for sandbath.

\section{9/14/11 Area 400 Comments Action Items}

- Reposition CV-412 as close to vessel as possible.

- Consider putting a check valve between HP/HT separator/stripper and HP/LT separator.

- Remember to change length of dip tube in HP/LT separator.

- Eliminate PSV-406; PSV-402; PSV-404 in 400 HP area drawing.

\section{9/14/11 Reviewing Dick's HAZOP Outline “Action Items”}

- Establish program to annually check safety valves.

- Good housekeeping.

- Identify egress - keep clear.

- Proper PPE, MSDS - "Be specific in PPE."

- Concerns with explosive hazards - hot surfaces.

- $\mathrm{H}_{2} \mathrm{~S}$ exposure and how to detect.

- Safety showers and eye washes - locate with thought.

- Stress corrosion and cracking - corrosive materials.

- Restriction on flex hoses - stainless braided type. 
- Radiation sources - controlling and training procedures for working around - signage.

- Second-floor eye wash/shower station.

- Helium sniffer - for leak checking.

- Air quality control permit - $\mathrm{SO}_{2}, \mathrm{H}_{2} \mathrm{~S}, \mathrm{CO}_{2}, \mathrm{NO}_{2}$.

- Hazardous waste - types and quantities.

- Control in crushing bottoms, keep dust and contamination at a minimum.

- Proper training of personnel before opening any valve or breaking apart fittings - use of proper PPE - gloves, face shield, respirator. 
P\&ID ACTION ITEMS

\begin{tabular}{|c|c|c|c|c|}
\hline Area & Action Item & $\begin{array}{c}\text { Person } \\
\text { Responsible }\end{array}$ & Action Taken & Date \\
\hline $100 \mathrm{H}$ & $\begin{array}{l}\text { Drain on bottom of vent line - stack } \\
\text { pipe in pipe }\end{array}$ & Dusty/Mark & $\begin{array}{l}\text { There is a drain on the bottom of the stack going out the roof. An additional drain valve has } \\
\text { been installed at the bottom of the vent line section running from the first up to the second } \\
\text { floor. }\end{array}$ & $11 / 1 / 2011$ \\
\hline $100 \mathrm{H}$ & Decide on $\mathrm{H}_{2}$ accumulator location & Mark/Dusty & $\begin{array}{l}\text { There will be no storage of } \mathrm{H}_{2} \text { in pressurized cylinders or vessels within the immediate } \\
\text { vicinity of the Accelergy system or below heated vessels on the second deck. }\end{array}$ & $5 / 28 / 2012$ \\
\hline $100 \mathrm{H}$ & $\begin{array}{l}\text { Determine location of } \mathrm{H}_{2} \text { six-pack - } \\
\text { review criteria }\end{array}$ & Mark & $\begin{array}{l}\text { A location for permanent placement of six-packs is being assessed. Preliminary plans for } \\
\text { temporary storage include placement of up to } 2 \text { six-packs east of the NCHT building. } \\
\text { Stainless steel tubing (1/4-inch OD) will connect the six-packs to the Accelergy process } \\
\text { through a distance of approximately } 60 \text { feet. The } \mathrm{H}_{2} \text { pressure will be regulated at the six- } \\
\text { packs to the pressure required for the Accelergy process. }\end{array}$ & $5 / 28 / 2012$ \\
\hline $100 \mathrm{H}$ & $\begin{array}{l}\text { Label exactly how } \mathrm{H}_{2} \text { connects to DCL } \\
\text { system }\end{array}$ & Mark & Changed on drawing Accelergy-v11.vsd. & $5 / 28 / 2012$ \\
\hline $100 \mathrm{H}$ & $\begin{array}{l}\text { Verify safety valves RV-6 RV-7 and } \\
\text { determine if can be reset for lower } \\
\text { pressure }\end{array}$ & Dusty/Mark & $\begin{array}{l}\text { Can only be factory set (Autoclave Engineers), currently set to } 14,500 \text { psi; a new safety } \\
\text { relief valve (PSV-116) with a } 6000 \text { psi relief set point has been installed to protect against } \\
\text { over pressurization of the } \mathrm{H}_{2} \text { accumulators. }\end{array}$ & $3 / 1 / 2012$ \\
\hline $100 \mathrm{H}$ & Add relief pressures on P\&IDs & Dusty & $\begin{array}{l}\text { Relief pressures to be updated on Accelergy-v7.vsd (RV1 = } 1500 \text { psi, RV2 = } 400 \text { psi, RV3 = } \\
14,500 \text { psi, RV6 }=14500 \text { psi, RV160 = 600 psi, RV130 = } 600 \text { psi). }\end{array}$ & $10 / 17 / 2011$ \\
\hline $100 \mathrm{H}$ & $\begin{array}{l}\text { Shutdown/start-up and operating logic to } \\
\text { P\&ID }\end{array}$ & Dusty & $\begin{array}{l}\mathrm{N}_{2} \text { compressor start-up can be taken from ESA start-up procedure. P\&ID can include two } \\
\text { manual valves for the compressor oil bypass that are used for start-up, along with a valve for } \\
\text { water supply. }\end{array}$ & $10 / 7 / 2011$ \\
\hline $100 \mathrm{H}$ & $\begin{array}{l}\text { Add all details on } \mathrm{N}_{2} \text { compressor such } \\
\text { as manufacturer maintenance procedure }\end{array}$ & Dusty & $\begin{array}{l}\mathrm{N}_{2} \text { compressor is a Fluitron Diaphragm with leak detection. The oil must be changed every } \\
500 \text { hours or } 6 \text { months, and O-rings and/or metal diaphragms should be changed if oil is seen } \\
\text { in the leak detection piping. It should be used at least every } 6 \text { months to keep lubrication. } \\
\text { See compressor user guide for further operation. }\end{array}$ & $10 / 7 / 2011$ \\
\hline $100 \mathrm{H}$ & $\begin{array}{l}\text { Volume release of } \mathrm{H}_{2} \text { and/or } \mathrm{H}_{2} \\
\text { accumulation }\end{array}$ & Mark/Dusty & $\begin{array}{l}\text { The equipment located in the upstairs barricade is of such a small volume, less than } 8 \text {-scfh } \\
\text { per vessel, that a localized flammable formation will be short-lived. The barricades provide } \\
\text { protection from a jet flame for those outside the barricade, and multiple egress locations } \\
\text { allow workers inside to vacate. The key concern in this location is ventilation, and it is } \\
\text { proposed that an "elephant trunk" will be used to add local ventilation during sample taking } \\
\text { to limit vapors and flammables gases in the region. The south barricade wall will also be } \\
\text { removed to allow for better access and air flow, as the hydrogen equipment will be located } \\
\text { near the north wall barricade. The flooring directly under the hydrogen filled equipment will } \\
\text { be replaced with grating and a liquid trap installed further underneath, allowing airflow from } \\
1^{\text {st }} \text { floor up and past the equipment while still protecting from liquid spills. The placement } \\
\text { behind the barricade should allow adequate ventilation without enough confinement for an } \\
\text { explosion hazard, but still keep the risk of the system within range as determined in the risk } \\
\text { assessment. Workers inside the barricade will be exposed to a higher risk but is taken upon } \\
\text { by project employees familiar with the system rather than the general worker population, and } \\
\text { flame and gas detection will be installed to provide hazard notification. }\end{array}$ & 9/23/2011 \\
\hline
\end{tabular}




\section{P\&ID ACTION ITEMS (continued)}

\begin{tabular}{|c|c|c|c|c|}
\hline Area & Action Item & $\begin{array}{c}\text { Person } \\
\text { Responsible }\end{array}$ & Action Taken & Date \\
\hline $100 \mathrm{~N}$ & Verify all electrical classification & Mark/Jim & $\begin{array}{l}\text { Motors for } \mathrm{N}_{2} \text { compressor and high-pressure pumps were cleared for use by electrical } \\
\text { inspector; thermostat (potential arcing device) in gear pump motors has been disconnected }\end{array}$ & $11 / 1 / 2011$ \\
\hline $100 \mathrm{~N}$ & $\begin{array}{l}\text { Hydrotest accumulators or pressure test } \\
\text { according to DOT testing }\end{array}$ & Jim & These are certified tanks with a DOT pressure rating of $10,000 \mathrm{psi}$. & $10 / 4 / 2011$ \\
\hline $100 \mathrm{~N}$ & $\begin{array}{l}\text { Verify how we do all of our reliefs; can't } \\
\text { use thermal oxidizer as a safety device }\end{array}$ & Mark & $\begin{array}{l}\text { Clean, dry reliefs from } \mathrm{H}_{2} \text { and } \mathrm{N}_{2} \text { supply will be directed to the existing } \mathrm{N}_{2} \text {-purged } 1 \frac{1}{2} \text {-inch } \\
\text { relief/vent line on the ESA system; } 1 \text {-inch CS vent lines independently connect Knock-Out } 1 \\
\text { and } 2 \text { to a new 2-inch dirty vent line; Knock-Out } 1 \text { serves the reliefs for the high-pressure } \\
\text { slurry and solvent flush pumps; Knock-Out } 2 \text { serves the reliefs for the bottoms stripper } \\
\text { accumulator and condensate accumulator. }\end{array}$ & $3 / 1 / 2012$ \\
\hline 100 & $\begin{array}{l}\text { Develop drawing showing how MFC } \\
\text { will be implemented }\end{array}$ & Mark & $\begin{array}{l}\text { Added on drawing Accelergy-v7.vsd; mass flow controllers are contained in two } \mathrm{N}_{2} \text { purged } \\
\text { Hoffman-type boxes; } \mathrm{H}_{2} \text { FCV's } 102 \text { and } 104 \text { are in one box and } \mathrm{N}_{2} \text { FCV } 106 \text { and a spare } \mathrm{H}_{2} \\
\text { FCV are in a second } \mathrm{N}_{2} \text { purged box; } \mathrm{N}_{2} \text { purge flow to each box will be controlled through a } \\
0 \text { to } 5 \text { psig regulator, a rotameter on an outlet port will show positive flow out of the box; } \\
\text { this method requires good sealing around penetrations and doors to maintain positive flow to } \\
\text { the outlet rotameter. }\end{array}$ & $9 / 23 / 2011$ \\
\hline 100 & $\begin{array}{l}\text { SOP needs to address what we will do in } \\
\text { case of loss of House } \mathrm{N}_{2} \text { /air to our purge } \\
\text { for control boxes }\end{array}$ & Mark & $\begin{array}{l}\text { Purges from house } \mathrm{N}_{2} \text { and house air will be used on DAQ, heater controller, VFD, and mass } \\
\text { flow controller boxes; loss of purge will be signaled on annunciator box in control room; } \\
\text { loss of purge will not shut down operation but will signal operator to investigate loss of } \\
\text { purge. }\end{array}$ & $9 / 19 / 2011$ \\
\hline 100 & $\begin{array}{l}\text { Delete burst pressure from drawing } \\
\text { legend change MWP to MOP or MAWP }\end{array}$ & Mark & $\begin{array}{l}\text { Changed on drawing Accelergy-v6.vsd; MOP set at } 3000 \text { psig, reference to burst pressure } \\
\text { removed. }\end{array}$ & $9 / 15 / 2011$ \\
\hline 100 & Add another check valve after CV-114 & Mark & Changed on drawing Accelergy-v6.vsd; CV-116 added after CV-114. & 9/15/2011 \\
\hline 100 & $\begin{array}{l}\text { Decide whether or not we need to } \\
\text { double valve or add a bleed line on } \\
\text { PIR/PI isolation valves }\end{array}$ & Jim & No PIR/PI process isolation valves are being used. & $5 / 10 / 2011$ \\
\hline 100 & $\begin{array}{l}\text { Safety sealed all valves to purged vent; } \\
\text { safety valves - PSV-104 and PSV-112 } \\
\text { were sealed }\end{array}$ & Mark & $\begin{array}{l}\text { Pressure safety valves } 104 \text { and } 112 \text { have been factory set at } 3300 \text { psig and are lead tag sealed } \\
\text { to prevent tampering. }\end{array}$ & $3 / 1 / 2012$ \\
\hline 100 & $\begin{array}{l}\text { Evaluate possible } \mathrm{N}_{2} \text { leak and raising } \mathrm{N}_{2} \\
\text { level in vicinity }\end{array}$ & Mark/Dusty & $\begin{array}{l}\text { The nitrogen compressor could create a localized area of low oxygen and become an } \\
\text { asphyxiation risk, but the required leak size to allow this to occur would be large enough to } \\
\text { be noticeable by any employee in the vicinity. Once again, ruptures are unlikely, and a leak } \\
\text { letting enough nitrogen into the atmosphere is easily heard by workers, allowing them to } \\
\text { take action. Because the gas is nonflammable and easily detected, it is recommended that the } \\
\text { nitrogen compressor can remain indoors. }\end{array}$ & $9 / 23 / 2011$ \\
\hline 200 & Change slurry mix tank temp to $300^{\circ} \mathrm{F}$ & Mark & $\begin{array}{l}\text { Changed on drawing Accelergy-v6.vsd; temperature changed from } 400^{\circ} \mathrm{F} \text { down to } 300^{\circ} \mathrm{F} \text { for } \\
\text { slurry mix and slurry feed tanks. }\end{array}$ & $9 / 15 / 2011$ \\
\hline 200 & $\begin{array}{l}\text { Determine operating pressure of product } \\
\text { tanks - would be advisable to be } 50 \text { psi } \\
\text { (if venting to thermal oxidizer) }\end{array}$ & Jim & $\begin{array}{l}\text { The design drawings were reviewed by the EERC engineering team, and it was determined } \\
\text { that the tanks were capable of withstanding } 50 \text { psi pressure. }\end{array}$ & $3 / 15 / 2012$ \\
\hline
\end{tabular}


P\&ID ACTION ITEMS (continued)

\begin{tabular}{|c|c|c|c|c|}
\hline Area & Action Item & $\begin{array}{c}\text { Person } \\
\text { Responsible }\end{array}$ & Action Taken & Date \\
\hline 200 & $\begin{array}{l}\text { Add } \mathrm{N}_{2} \text { purge to all tank vents } \\
\text { lines/blanket tanks }\end{array}$ & Mark & $\begin{array}{l}\text { Changed on drawing Accelergy-v6.vsd; } \mathrm{N}_{2} \text { purges added for slurry mix, slurry feed, and } \\
\text { solvent flush tanks. }\end{array}$ & $9 / 15 / 2011$ \\
\hline 200 & Add that the Viking pumps have VFDs & Mark & Changed on drawing Accelergy-v6.vsd; VFD reference added to motor description & $9 / 20 / 2011$ \\
\hline 200 & $\begin{array}{l}\text { Check to see if we can get Group B } \\
\text { motors that are VFD rated }\end{array}$ & Mark & $\begin{array}{l}\text { WEG offers Class 1, Div 2, Group B, C, D three-phase TEFC motor with Class F insulation, } \\
\text { VFD rated. }\end{array}$ & $9 / 20 / 2011$ \\
\hline 200 & $\begin{array}{l}\text { Verify that the motors have no arcing or } \\
\text { sparking }\end{array}$ & Jim & $\begin{array}{l}\text { Motors for the slurry/solvent gear pumps are Class } 1 \text { Div } 1 \text { Group C\&D explosion proof } \\
\text { motors with T3C }(160 \mathrm{C}) \text { max surface temperature rating, the manufacturer indicated motors } \\
\text { have thermostats that can be arcing but no brushes or switches, the thermostats have been } \\
\text { disconnected; motors for the mixers are Class } 1 \text { Div } 1 \text { Group C } \& D \text { hazardous location } \\
\text { motors with T3C ( } 160 \mathrm{C}) \text { max surface temperature rating, the manufacturer indicated that } \\
\text { the motor is nonarcing or sparking. }\end{array}$ & $11 / 1 / 2011$ \\
\hline 200 & Provide a flush option for Viking pumps & Mark & Flush line shown as a future option; no flush supply pump currently available. & $5 / 4 / 2012$ \\
\hline 200 & $\begin{array}{l}\text { Add flow direction on cooling water on } \\
\text { each tank condenser (change valves to } \\
\text { rotometers) }\end{array}$ & Mark & $\begin{array}{l}\text { Changed on drawing Accelergy-v6.vsd for slurry mix tank; condensers removed from slurry } \\
\text { feed and solvent flush tanks. }\end{array}$ & $9 / 15 / 2011$ \\
\hline 200 & $\begin{array}{l}\text { Consider adding external relief on the } 3 \\
\text { Viking gear pumps or see if we can } \\
\text { remove and check the internal reliefs }\end{array}$ & Mark & $\begin{array}{l}\text { Changed on drawing Accelergy-v6.vsd; external pressure safety valves PSV-206, -208, and } \\
-210 \text { added for slurry mix, slurry feed, and solvent flush tank circulation pumps, } \\
\text { respectively; relief set points are } 100 \text { psig for each valve. }\end{array}$ & $9 / 15 / 2011$ \\
\hline 200 & $\begin{array}{l}\text { Display more detail such as flex } \\
\text { connection, show scales }\end{array}$ & Mark & $\begin{array}{l}\text { Changed on drawing Accelergy-v6.vsd; Flex Lines FL-202, }-204 \text {, and -206 added to slurry } \\
\text { mix tank and Flex Lines }-208,-210,-212 \text {, and -214 added to slurry feed tank at gear pump } \\
\text { inlets, recycle lines, and } \mathrm{N}_{2} \text { vent lines. }\end{array}$ & 9/20/2011 \\
\hline 200 & $\begin{array}{l}\text { Add all design temps and press on } \\
\text { P\&IDs }\end{array}$ & Mark & This is in progress and is expected to be complete before the system is operated. & Ongoing \\
\hline 200 & Address coal moisture in the process & Ramesh & $\begin{array}{l}\text { All input coals will be dried to } 2 \%-3 \% \text { moisture prior to charging, and the coal percentage in } \\
\text { feed slurry will be based on } 2 \%-3 \% \text { moisture. }\end{array}$ & $10 / 4 / 2011$ \\
\hline 300 & $\begin{array}{l}\text { Slurry preheater need to edit and change } \\
\text { description }\end{array}$ & Mark & $\begin{array}{l}\text { Slurry will be preheated (from } 300^{\circ} \mathrm{F} \text { up to } 570^{\circ} \mathrm{F} \text { ) within the electrically heat-traced } 1 / 2 \text {-inch } \\
\text { OD, } 0.083 \text {-inch wall tubing supplying slurry from the outlet of the HP slurry pump to the } \\
\text { reactor inlet. }\end{array}$ & $5 / 4 / 2012$ \\
\hline 300 & $\begin{array}{l}\text { Change where the } \mathrm{H}_{2} \text { is mixed with the } \\
\text { slurry to before the sand bath- possibly } \\
\text { before preheat }\end{array}$ & Mark & $\begin{array}{l}\text { Changed on drawing Accelergy-v6.vsd; } \mathrm{H}_{2} \text { added to slurry just before entering sand bath } \\
\text { vessel; will operate slurry and } \mathrm{H}_{2} \text { preheaters at } 570^{\circ} \mathrm{F} \text {. }\end{array}$ & 9/16/2011 \\
\hline 300 & $\begin{array}{l}\text { Move or eliminate PSV302 because of } \\
\text { the change in the } \mathrm{H}_{2} \text { addition - need to } \\
\text { discuss this design change - all reactor } \\
\text { components designed higher than } \\
\text { everything else }\end{array}$ & Mark & $\begin{array}{l}\text { Changed on drawing Accelergy-v6.vsd; removed PSV-302; vessel and piping components } \\
\text { have } 3500 \text { psig MAWP which is above maximum gas and slurry supply pressure. }\end{array}$ & $9 / 16 / 2011$ \\
\hline 300 & $\begin{array}{l}\text { Determine the appropriate location for } \\
\text { the sand bath heater (add TC) in exit } \\
\text { pipe/determine proper size of exit }\end{array}$ & Jim & Sand bath heater will be located on the first (main) level. & \\
\hline 300 & Put $\mathrm{N}_{2}$ usage of sand bath on P\&ID & Mark & Changed on drawing Accelergy-v6.vsd; $\mathrm{N}_{2}$ usage approximately 360 scfh. & $9 / 15 / 2011$ \\
\hline 300 & $\begin{array}{l}\text { Change sand bath to } \mathrm{N}_{2} \text { instead of air for } \\
\text { fluidization }\end{array}$ & Mark & Changed on drawing Accelergy-v6.vsd; $\mathrm{N}_{2}$ replacing air as fluidizing gas. & $9 / 15 / 2011$ \\
\hline
\end{tabular}


P\&ID ACTION ITEMS (continued)

\begin{tabular}{|c|c|c|c|c|}
\hline Area & Action Item & $\begin{array}{c}\text { Person } \\
\text { Responsible }\end{array}$ & Action Taken & Date \\
\hline 300 & $\begin{array}{l}\text { Low-flow switch that will turn off } \\
\text { heaters in sand bath }\end{array}$ & Mark & $\begin{array}{l}\text { Pressure transducer PIR-306 (placed upstream of the sand bath gas distributor) will function } \\
\text { to indicate loss/reduced } \mathrm{N}_{2} \text { flow to the sand bath; a visual alarm on the computer control } \\
\text { screen will alert the operator to turn heaters SPs down or off; future PC control scheme } \\
\text { could have automated shutdown of heaters. }\end{array}$ & $5 / 4 / 2012$ \\
\hline 300 & $\begin{array}{l}\text { Verify proper labeling of MV-304 and } \\
\text { FIC-302 }\end{array}$ & Mark & $\begin{array}{l}\text { Changed on drawing Accelergy-v6.vsd; MV-304 removed; FIC-302 functions as flow } \\
\text { control and rate display. }\end{array}$ & $9 / 15 / 2011$ \\
\hline 300 & $\begin{array}{l}\text { Check all check valve symbols, and } \\
\text { make sure they are correct }\end{array}$ & Mark & Changed on drawing Accelergy-v6.vsd; flow direction of check valve CV-304 corrected. & $9 / 15 / 2011$ \\
\hline 300 & $\begin{array}{l}\text { Consider changing our manifold design } \\
\text { using } 1 \text { ) sintered metal thimbles or } 2 \text { ) } \\
\text { sintered metal grid above support plate } \\
\text { with properly sized holes }\end{array}$ & Jim & $\begin{array}{l}\text { The drain is on the bottom of the fluid-bed sand bath. Adding a sintered metal or similar } \\
\text { screen will not allow bed sand to be drained. We will assess after short-term runs if } \\
\text { penetration of sand into the manifold is an issue and if re-design is required. }\end{array}$ & $5 / 10 / 2012$ \\
\hline 400 & $\begin{array}{l}\text { Review need for reliefs on vessels in } \\
400 \text { HP P\&ID }\end{array}$ & Mark & $\begin{array}{l}\text { Changed on drawing Accelergy-v6.vsd; removed pressure safety valves PSV-402 and -406; } \\
\text { vessel and piping components have } 3500 \text { psig MAWP which is above maximum gas and } \\
\text { slurry supply pressure. }\end{array}$ & $9 / 16 / 2011$ \\
\hline 400 & $\begin{array}{l}\text { Heat exchangers - sublimation of } \\
\text { ammonia and chlorides need to have a } \\
\text { capability for water injection at the front } \\
\text { of HX-406 }\end{array}$ & Jim & $\begin{array}{l}\text { This modification was done by adding a tee and high-pressure valve to give the capability } \\
\text { for water injection. }\end{array}$ & $11 / 23 / 2011$ \\
\hline 400 & $\begin{array}{l}\text { Evaluate potential for } \mathrm{H}_{2} \text { embrittlement } \\
\text { in } \mathrm{HX}-406 \text { and } \mathrm{HX}-408\end{array}$ & Jim & $\begin{array}{l}\text { We will do periodic checking of the critical areas of the system to ensure that no } \\
\text { embrittlement is taking place. The materials used in the construction of the DCL are of the } \\
\text { highest quality that was available to us. Also, our past experience with these materials in a } \\
\mathrm{H}_{2} \text { atmosphere has shown them to be capable of the service. }\end{array}$ & Ongoing \\
\hline 400 & $\begin{array}{l}\text { Consider switching our sulfur scrubbers } \\
\text { to } 400 \text { low pressure after condensate } \\
\text { accumulator before thermal oxidizer }\end{array}$ & Mark & $\begin{array}{l}\text { Changed on drawing Accelergy-v8.vsd; removed sulfur scrubber pressure vessels; current } \\
\text { plan is destruction of process effluent gas in an existing flare. }\end{array}$ & $5 / 4 / 2012$ \\
\hline 400 & $\begin{array}{l}\text { Develop a procedure for operating with } \\
\text { our nuclear sources open }\end{array}$ & Mark & $\begin{array}{l}\text { A radiation survey has been completed for closed and opened sources; operating personnel } \\
\text { will be instructed in the location of sources and principle of ALARA for minimizing } \\
\text { exposure while performing maintenance, taking samples, or doing field readings; area } \\
\text { signage indicates the presence and locations of nuclear sources; the process area with the } \\
\text { sources will also have markings on the decking to show areas where sustained work } \\
\text { activities may require sources to be closed; discussion of operation with open nuclear } \\
\text { sources will be included in the operations manual. }\end{array}$ & Ongoing \\
\hline 400 & $\begin{array}{l}\text { Eliminate Valve } 406 \text { on } 400 \mathrm{LP} \text { and put } \\
\text { AV-410 as close as possible to bottom } \\
\text { of bottoms stripper accumulator }\end{array}$ & Mark & $\begin{array}{l}\text { Changed on drawing Accelergy-v6.vsd; moved automated Valves AV-410 and -412 to be } \\
\text { close-coupled to bottom of the bottoms stripper accumulator. }\end{array}$ & $9 / 15 / 2011$ \\
\hline 400 & Look at process of grinding bottoms & Jim & $\begin{array}{l}\text { Preliminary laboratory trials have shown that freezing the bottoms followed by grinding in a } \\
\text { ball-media tumbling mill can produce the desired recycle feedstock. }\end{array}$ & Ongoing \\
\hline
\end{tabular}


RISK ASSESSMENT ACTION ITEMS

\begin{tabular}{|c|c|c|c|c|}
\hline Area & Action Item & $\begin{array}{c}\text { Person } \\
\text { Responsible }\end{array}$ & Action Taken & Date \\
\hline & $\begin{array}{l}\text { Evaluate second-floor layout, and determine } \\
\text { how to minimize confined space for operator } \\
\text { safety and access for maintenance }\end{array}$ & Jim & $\begin{array}{l}\text { Removed the south wall of the second-floor barricade and relocated all of the mix } \\
\text { tanks and related pumps to the } 1 \text { st level. Removed a section of the solid flooring } \\
\text { below the second-floor pressure vessels to allow better air circulation and } \\
\text { ventilation. }\end{array}$ & $10 / 3 / 2011$ \\
\hline \multirow[t]{4}{*}{$100 \mathrm{H}$} & $\begin{array}{l}\text { Evaluate the possibility of relocating } \mathrm{H}_{2} \\
\text { compressor }\end{array}$ & Dusty & $\begin{array}{l}\text { The ESA compressor will be used for compression of } \mathrm{N}_{2} \text { or } \mathrm{N}_{2} / \mathrm{He} \text { blends only. } \\
\text { This compressor will not be used for } \mathrm{H}_{2} \text { compression. } \mathrm{H}_{2} \text { will be supplied from six- } \\
\text { packs that will be placed external to the NCHT building. There will be no internal } \\
\mathrm{H}_{2} \text { storage within proximity to the Accelergy system or below the hot vessels } \\
\text { located on the second deck. }\end{array}$ & $5 / 28 / 2012$ \\
\hline & $\begin{array}{l}\text { Evaluate location and safe operability of the } \\
\text { thermal oxidizer }\end{array}$ & Jim & $\begin{array}{l}\text { The DCL system will utilize an existing flare for destruction of the product gas; the } \\
\text { thermal oxidizer will be shut off and its fuel supply locked out during DCL system } \\
\text { operation. }\end{array}$ & Ongoing \\
\hline & $\begin{array}{l}\text { Evaluate existing electrical equipment relative to } \\
\text { the area classification }\end{array}$ & Jim & $\begin{array}{l}\text { All of the electrical motors were checked, and they all meet the electrical } \\
\text { requirement for the NCHT facility. We are only using heating cables and clam- } \\
\text { shell-like heaters that meet the electrical code requirements. Any other electrical } \\
\text { devices that will be added in the future will also be evaluated to meet the code } \\
\text { requirements. }\end{array}$ & $2 / 3 / 2012$ \\
\hline & $\begin{array}{l}\text { Evaluate adequacy of ventilation and possible need } \\
\text { for ducting in/around second-floor equipment }\end{array}$ & Ken/Christin & $\begin{array}{l}\text { Trunk lines will be installed to address additional ventilation requirements after } \\
\text { system fabrication, pressure testing, and shakedown have been completed. }\end{array}$ & Ongoing \\
\hline $100 \mathrm{H}$ & $\begin{array}{l}\text { Reevaluate need for barricading with respect to } \\
\text { predicted flame jet ignition }\end{array}$ & Dusty/Mark/Jim & $\begin{array}{l}\text { Some barricading has been eliminated; the remaining barricading functions to } \\
\text { protect personnel entering the pilot area from the second-floor lobby and also to } \\
\text { minimize possible flame projection to adjacent equipment; the barricading also } \\
\text { functions to provide equipment support. }\end{array}$ & $1 / 10 / 2012$ \\
\hline 200 & $\begin{array}{l}\text { Add drip pans and liquid containment around } \\
\text { slurry and solvent tanks }\end{array}$ & Mark & $\begin{array}{l}\text { All slurry and solvent tanks and associated pumps have been moved to the first } \\
\text { floor; each tank has a spill tray in case of leak; need to look at method for blocking } \\
\text { off floor drain. }\end{array}$ & Ongoing \\
\hline $100 \mathrm{H}$ & $\begin{array}{l}\text { Evaluate potential of light gases being trapped } \\
\text { under solid floor decking }\end{array}$ & Ken/Christin & $\begin{array}{l}\text { This has been addressed with the removal of the section of solid decking on the } \\
\text { second level. }\end{array}$ & $10 / 3 / 2011$ \\
\hline $100 \mathrm{H}$ & $\begin{array}{l}\text { Evaluate possibility of using } \mathrm{H}_{2} \text { six-packs and } \\
\text { eliminating need for electric } \mathrm{H}_{2} \text { compressor }\end{array}$ & Mark/Jim/Ken & $\begin{array}{l}\text { A location for permanent placement of six-packs is being assessed. Preliminary } \\
\text { plans for temporary storage include placement of up to } 2 \text { six-packs east of the } \\
\text { NCHT building. Stainless steel tubing ( } 1 / 4 \text {-inch OD) will connect the six-packs to } \\
\text { the Accelergy process through a distance of approximately } 60 \text { feet. The } \mathrm{H}_{2} \text { pressure } \\
\text { will be regulated at the six-packs to the pressure required for the Accelergy process. } \\
\text { The DCL system } \mathrm{H}_{2} \text { utilization rate is } \sim 75 \text { scfh, six-pack volume is } 2550 \text { scf at } \\
6000 \text { psig. Utilization to } 3000 \text { psig or } 1 / 2 \text { original volume would give } 17 \text { hours of } \\
\text { operation, and a } 100 \text {-hour run would require } 5.88 \text { six-packs. }\end{array}$ & $5 / 28 / 2012$ \\
\hline $100 \mathrm{H}$ & $\begin{array}{l}\text { Evaluate possible use of air-driven booster for six- } \\
\text { pack scavenging }\end{array}$ & Mark & $\begin{array}{l}\text { The use of a scavenging compressor would facilitate the need for limited additional } \\
\mathrm{H}_{2} \text { storage in the event that the booster had mechanical issues. This would give time } \\
\text { to switch out to another six-pack. }\end{array}$ & $5 / 28 / 2012$ \\
\hline All & Perform valve failure action assessment & Mark & $\begin{array}{l}\text { 1st iteration completed; will incorporate necessary action responses into SOP and } \\
\text { computer control logic. }\end{array}$ & Ongoing \\
\hline
\end{tabular}


RISK ASSESSMENT ACTION ITEMS (continued)

\begin{tabular}{|c|c|c|c|c|}
\hline Area & Action Item & $\begin{array}{c}\text { Person } \\
\text { Responsible } \\
\end{array}$ & Action Taken & Date \\
\hline All & $\begin{array}{l}\text { Assess impact of possible loss of house } \\
\text { air pressure }\end{array}$ & Mark & $\begin{array}{l}\text { House air is needed for operation of blocking and control valves; pressure transducer } \\
\text { PIR-002 has been added to monitor gas supply pressure; programmable low-pressure } \\
\text { alarm limits on the control computer will alert operations staff to a low-pressure } \\
\text { condition; regulated } \mathrm{N}_{2} \text { at slightly lower pressure than house air pressure will provide } \\
\text { a pneumatic pressure source in the instance that house air pressure is lost; check } \\
\text { valves in both the air and } \mathrm{N}_{2} \text { supply lines prevent backflow of the high-pressure gas } \\
\text { into the lower-pressure source line; response actions have been included in the SOP. }\end{array}$ & $4 / 1 / 2012$ \\
\hline $100 \mathrm{H}, \mathrm{N}$ & $\begin{array}{l}\text { Evaluate need for surge flow devices } \\
\text { (lines entering building, flow taken off } \\
\text { supply header) to limit gas release in } \\
\text { case of fitting failure }\end{array}$ & Dusty/Mark & $\begin{array}{l}\text { Surge devices should be used on any large-volume section of piping, specifically on } \\
\mathrm{H}_{2} \text { six-packs. High-pressure tubing has been used between the } \mathrm{N}_{2} \text { compressor, } \mathrm{N}_{2} \\
\text { accumulators, and high-pressure } \mathrm{N}_{2} \text { regulator to reduce the orifice size of any leaks in } \\
\text { case of regulator failure. }\end{array}$ & $10 / 7 / 2011$ \\
\hline 400 & $\begin{array}{l}\text { Evaluate need for check valves (between } \\
\text { process vessels) to limit gas release in } \\
\text { case of fitting failure }\end{array}$ & Mark & $\begin{array}{l}\text { A potential location for a check valve is between the HP/HT and HP/LT vessels; } \\
\text { upstream of the heat exchangers may present problems with possible plugging from } \\
\text { condensed heavy organics or coal solids. Downstream of the heat exchangers } \\
\text { provides a low-temperature location but with two-phase flow. The overall system } \\
\text { volume is small, and presently, there are no plans to incorporate a check valve } \\
\text { between the vessels. }\end{array}$ & $9 / 20 / 2011$ \\
\hline All & $\begin{array}{l}\text { Evaluate need for E-stop(s) for } \\
\text { controlled automated shutdown in } \\
\text { various emergency situations }\end{array}$ & Mark & $\begin{array}{l}\text { E-stops are presently not incorporated in the current PC control program; near-term } \\
\text { action responses in the SOP will incorporate manual intervention; E-stop concept(s) } \\
\text { will be outlined and programmed at a later date. }\end{array}$ & Ongoing \\
\hline All & Develop shutdown matrix & Mark & $\begin{array}{l}\text { The standard operating procedure contains instructions for a normal, controlled } \\
\text { shutdown via manual interface with the PC control/data acquisition program; the first } \\
\text { iteration of an emergency shutdown procedure has been developed that utilizes } \\
\text { manual interface with the computer; future versions of the computer control program } \\
\text { will contain an E-stop emergency shutdown. }\end{array}$ & Ongoing \\
\hline 200 & $\begin{array}{l}\text { Add rupture disc before safety relief } \\
\text { valve on HP pumps }\end{array}$ & Mark & $\begin{array}{l}\text { Rupture disks will not be incorporated; evaluating use of HP pump internal hydraulic } \\
\text { relief as more reliable than rupture disks. }\end{array}$ & $5 / 4 / 2012$ \\
\hline $200,300,400$ & $\begin{array}{l}\text { Incorporate low/no-flow cut-off } \\
\text { procedure for vessel and coil heaters }\end{array}$ & Mark & $\begin{array}{l}\text { Over-temperature thermocouples have been added to electrically heated high-pressure } \\
\text { tubing and vessels; the data acquisition and control program will allow user-defined } \\
\text { temperature limits for the heater controllers and over-temperature thermocouples; the } \\
\text { operator will take corrective action to turn heaters down or off. }\end{array}$ & $5 / 1 / 2012$ \\
\hline $200,300,400$ & $\begin{array}{l}\text { Implement protocol/procedures for } \\
\text { dealing with plugs }\end{array}$ & Jim & $\begin{array}{l}\text { This has been discussed, and we are still developing the proper procedure to prevent } \\
\text { any equipment or personnel injury. }\end{array}$ & \\
\hline 300 & $\begin{array}{l}\text { Evaluate separate stack for sand bath hot } \\
\mathrm{N}_{2} \text { venting }\end{array}$ & Jim & $\begin{array}{l}\text { A separate stack for the sand bath fluidizing } \mathrm{N}_{2} \text { vent has been installed; this stack } \\
\text { incorporates a drain valve and a water-cooled heat exchanger to reduce the } \mathrm{N}_{2} \\
\text { temperature before venting to the NCHT roof. }\end{array}$ & $3 / 1 / 2012$ \\
\hline
\end{tabular}


RISK ASSESSMENT ACTION ITEMS (continued)

\begin{tabular}{|c|c|c|c|c|}
\hline Area & Action Item & $\begin{array}{c}\text { Person } \\
\text { Responsible }\end{array}$ & Action Taken & Date \\
\hline 400 & $\begin{array}{l}\text { Reposition CV-412 as close to vessel as } \\
\text { possible }\end{array}$ & Jim & $\begin{array}{l}\mathrm{CV}-412 \text { has been placed as close as possible to the inlet of the HP/HT } \\
\text { stripper/separator in the stripping line; similarly CV- } 304 \text { has been placed as close as } \\
\text { possible to the point where gas mixes with the slurry and the inlet of the slurry } \\
\text { reactor. }\end{array}$ & $9 / 22 / 2011$ \\
\hline 400 & $\begin{array}{l}\text { Consider putting a check valve between HP/HT } \\
\text { separator/stripper and HP/LT separator }\end{array}$ & Mark & $\begin{array}{l}\text { A potential location for a check valve is between the HP/HT and HP/LT vessels; } \\
\text { upstream of the heat exchangers may present problems with possible plugging from } \\
\text { condensed heavy organics or coal solids. Downstream of the heat exchangers } \\
\text { provides a low-temperature location but with two-phase flow. The overall system } \\
\text { volume is small, and presently, there are no plans to incorporate a check valve } \\
\text { between the vessels. }\end{array}$ & $9 / 20 / 2011$ \\
\hline 400 & Change length of dip tube in HP/LT separator & Mark & $\begin{array}{l}\text { Changed on drawing Accelergy-v6.vsd; dip tube in HP/LT separator should end } \\
\text { below concentric reducer; this was a drawing error not a construction error. }\end{array}$ & $9 / 15 / 2011$ \\
\hline \multirow[t]{10}{*}{400} & $\begin{array}{l}\text { Eliminate PSV-406; PSV-402; PSV-404 in } 400 \\
\text { high-pressure drawing }\end{array}$ & Mark & $\begin{array}{l}\text { Changed on drawing Accelergy-v6.vsd; pressure safety valves PSV-402, }-404 \text {, and - } \\
406 \text { removed; tubing and vessels have } 3500 \text { psig MAWP, which is higher than } \\
\text { maximum gas and slurry supply pressure. }\end{array}$ & 9/15/2011 \\
\hline & $\begin{array}{l}\text { Establish program to annually check safety } \\
\text { valves }\end{array}$ & Jim & $\begin{array}{l}\text { This has been discussed, and we are still developing the proper procedure to prevent } \\
\text { any equipment or personnel injury. }\end{array}$ & Ongoing \\
\hline & Establish and maintain good housekeeping & Jim & $\begin{array}{l}\text { Good housekeeping will be continuously emphasized, especially with respect to } \\
\text { preventing trip or other injury hazards. }\end{array}$ & Ongoing \\
\hline & Identify egress - keep clear & Jim & Egress signage has been ordered and received but not yet mounted. & Ongoing \\
\hline & Proper PPE, MSDS - “Be specific in PPE” & Christin & & \\
\hline & Concerns with explosive hazards - hot surfaces & Dusty & $\begin{array}{l}\text { Hot surfaces are an ignition concern. These should be limited by encasing the hot } \\
\text { surface in insulation to ensure that gas will not likely reach autoignition temperature } \\
\text { except if it is leaking from the hot surface process. Increased ventilation around hot } \\
\text { surfaces will also help lower ignition probability from a hot surface. }\end{array}$ & $10 / 7 / 2011$ \\
\hline & $\mathrm{H}_{2} \mathrm{~S}$ exposure and how to detect & Ramesh & Portable $\mathrm{H}_{2} \mathrm{~S}$ monitor is currently being used, and will be used during operation. & \\
\hline & Safety showers and eye wash locations & Ken/Christin & $\begin{array}{l}\text { EERC Safety Office is looking at the need for a shower/eye wash station on the } \\
\text { second-floor process area. }\end{array}$ & Ongoing \\
\hline & $\begin{array}{l}\text { Stress corrosion and cracking - corrosive } \\
\text { materials }\end{array}$ & Doug & $\begin{array}{l}\text { Prior to purchasing all materials and equipment, every effort was made to address this } \\
\text { possibility. Will monitor all equipment and vessels closely after operation commences } \\
\text { for any such occurrences. }\end{array}$ & $1 / 3 / 2012$ \\
\hline & $\begin{array}{l}\text { Restriction on flex hoses - stainless braided } \\
\text { type }\end{array}$ & Jim & $\begin{array}{l}\text { All flexible hoses are constructed of a ribbed tube enclosed within a braided } \\
\text { protective exterior. The ribbed tube and exterior braiding are made of } 316 \mathrm{SS} \text {. The } \\
\text { maximum service temperature is } 1250^{\circ} \mathrm{F} \text {. The } 1 \text {-inch hoses used on the mix, feed, and } \\
\text { flush solvent tanks are rated at } 718 \mathrm{psi} \text { at } 72^{\circ} \mathrm{F} \text {. Maximum expected temperature is } \\
300^{\circ} \mathrm{F} \text {. The hoses are designed to withstand vibration and misalignment. The safety } \\
\text { reliefs on the gear pumps are set at } 100 \text { psig so the maximum pressure rating of the } \\
\text { hoses will not be exceeded. }\end{array}$ & $5 / 10 / 2012$ \\
\hline
\end{tabular}


RISK ASSESSMENT ACTION ITEMS (continued)

\begin{tabular}{|c|c|c|c|c|}
\hline Area & Action Item & $\begin{array}{c}\text { Person } \\
\text { Responsible }\end{array}$ & Action Taken & Date \\
\hline & $\begin{array}{l}\text { Radiation sources - controlling and training } \\
\text { procedures for working around - signage }\end{array}$ & Ken/Christin & $\begin{array}{l}\text { Mark and Jim have taken training from UND; before operation commences, other } \\
\text { personnel that will be involved with the opening or closing of the sources will take } \\
\text { the training at UND. }\end{array}$ & Ongoing \\
\hline & Second-floor eye wash/shower station & Ken/Christin & & \\
\hline & Helium sniffer - for leak-checking & Mark & A He/ $\mathrm{H}_{2}$ sniffer has been purchased. & $4 / 26 / 2012$ \\
\hline & $\begin{array}{l}\text { Air quality control permit }-\mathrm{SO}_{2}, \mathrm{H}_{2} \mathrm{~S}, \mathrm{CO}_{2} \text {, } \\
\mathrm{NO}_{2}\end{array}$ & Christin & $\begin{array}{l}\text { Data have been provided to EERC Safety Office Manager Ken Grohs regarding } \\
\text { potential maximum production of } \mathrm{H}_{2} \mathrm{~S}\left(\text { and/or } \mathrm{SO}_{2}\right) \text {. }\end{array}$ & 9/19/2011 \\
\hline & Hazardous waste - types and quantities & Ramesh & $\begin{array}{l}\text { Still compiling complete list of all waste materials that will be generated during DCL } \\
\text { system operation. Currently have an existing EERC protocol on storage and disposal } \\
\text { of hazardous materials. }\end{array}$ & Ongoing \\
\hline & $\begin{array}{l}\text { Control in crushing bottoms, keep dust and } \\
\text { contamination at a minimum }\end{array}$ & Jim & Will be completed when exact method for bottoms crushing has been established. & Ongoing \\
\hline & $\begin{array}{l}\text { Proper training of personnel before opening any } \\
\text { valve or breaking apart fittings - use of proper } \\
\text { PPE - gloves, face shield, respirator }\end{array}$ & Jim & $\begin{array}{l}\text { Proper training will need to be performed for all personnel working on the system. } \\
\text { Ventilation trunks will be required any time the process is opened to the environment } \\
\text { if flammable gases or toxic vapors could be released. Processes should be purged of } \\
\text { gases before opening, as the classification of a Division II is that vapors and gases are } \\
\text { not expected to be present except through failure. Training is initiated during } \\
\text { construction and installation of various system components and will continue as } \\
\text { equipment additions and modifications made. }\end{array}$ & Ongoing \\
\hline
\end{tabular}


RESPONSIBLE PERSONNEL

\begin{tabular}{lll}
\hline ID & Full Name & Position/Function \\
\hline Ted & Ted R. Aulich & Project Manager \\
Greg & Gregory T. Dvorak & Programming \\
Ken & Ken L. Grohs & Manager, Facilities and Safety \\
Doug & Douglas J. Hajicek & Senior Design Engineer \\
Bob & Robert R. Jensen & Programming \\
Dusty & Dustin P. McNally & Hydrogen Safety/Risk Assessment \\
Mark & Mark A. Musich & Project Engineer \\
Christin & Christin R. McWaters & Facilities and Safety \\
Ramesh & Ramesh K. Sharma & Lead Chemist, Process Technologist \\
\hline
\end{tabular}




\section{AUTOMATED VALVE LIST}

\begin{tabular}{|c|c|c|c|}
\hline Area & Tag No. & Name & Actuation \\
\hline 100 & AV 102 & Hydrogen six-pack isolation & ATO \\
\hline 100 & AV 104 & Hydrogen accumulator/MFC isolation & ATO \\
\hline 100 & AV 106 & Nitrogen accumulator/MFC isolation & ATC \\
\hline 100 & AV 110 & Reaction hydrogen MFC - blocking & ATO \\
\hline 100 & AV 112 & Purge nitrogen MFC - blocking & ATC \\
\hline 100 & AV 114 & Hydrogen/nitrogen isolation & ATO \\
\hline 200 & AV 202 & Slurry cutoff & ATO \\
\hline 200 & AV 204 & Solvent flush cutoff & ATC \\
\hline 400 & AV 402 & HP/HT separator/stripper - top lock valve & ATO \\
\hline 400 & AV 404 & HP/HT separator/stripper - bottom lock valve & ATO \\
\hline 400 & AV 406 & HP/LT separator - top lock valve & ATO \\
\hline 400 & AV 408 & HP/LT separator - bottom lock valve & ATO \\
\hline 400 & AV 410 & Bottoms stripper accumulator - top lock & ATO \\
\hline 400 & AV 412 & Bottoms stripper accumulator - bottom lock & ATO \\
\hline 400 & AV 414 & Condensate accumulator - top lock valve & ATO \\
\hline 400 & AV 416 & Condensate accumulator - bottom lock valve & ATO \\
\hline 400 & PCV 418 & Pressure Control Valve 418 & ATC \\
\hline 400 & PCV 420 & Pressure Control Valve 420 & ATC \\
\hline
\end{tabular}




\section{LOSS OF SUPPLY AIR}

\begin{tabular}{|c|c|c|c|}
\hline $\begin{array}{l}\text { Step } \\
\text { No. }\end{array}$ & Action & & Computer/Field \\
\hline 1 & Toggle all $\mathrm{H}_{2} \mathrm{AV}$ valves to closed position. & Manual/automatic & Computer \\
\hline 2 & Input $0 \%$ flow on $\mathrm{H}_{2}$ MFCs. & Manual/automatic & Computer \\
\hline 3 & Toggle all $\mathrm{N}_{2} \mathrm{AV}$ valves to open position. & Manual/automatic & Computer \\
\hline 4 & Toggle flush solvent supply blocking valve to open position. & Manual/automatic & Computer \\
\hline 5 & Toggle slurry supply blocking valve to closed position. & Manual/automatic & Computer \\
\hline 6 & Reduce preheater, reactor, and pressure vessel temperature S's. & Manual/automatic & Computer \\
\hline 7 & $\begin{array}{l}\text { Toggle all top lock and bottom lock valves from automatic to } \\
\text { manual mode (valves will default to closed state). }\end{array}$ & Manual & Computer \\
\hline 8 & Close HV upstream of PCV. & Manual & Field \\
\hline 9 & $\begin{array}{l}\text { Assess cause of failure and time required for repair - for repairs } \\
\text { lasting longer than } 5 \text { minutes, proceed to Step } 18 .\end{array}$ & & \\
\hline 10 & $\begin{array}{l}\text { Reset valve position and/or operating mode to normal on } \\
\text { computer. }\end{array}$ & Manual & Computer \\
\hline 11 & $\begin{array}{l}\text { Verify cycling of top lock and bottom lock valves for all } \\
\text { separators/accumulators. }\end{array}$ & Manual & Computer \\
\hline 12 & Open HV upstream of PCV. & Manual & Field \\
\hline 13 & $\begin{array}{l}\text { Demonstrate control of system pressure through manual cycling } \\
\text { of PCV. }\end{array}$ & Manual & Computer \\
\hline 14 & $\begin{array}{l}\text { Establish normal system pressure and toggle to automatic } \\
\text { pressure control. }\end{array}$ & Manual & Computer \\
\hline 15 & Toggle all $\mathrm{H}_{2} \mathrm{AV}$ valves to open position. & Manual & Computer \\
\hline 16 & Slowly establish normal flows on $\mathrm{H}_{2}$ MF's. & Manual & Computer \\
\hline 17 & Proceed to Step 31. & & \\
\hline 18 & Establish $\mathrm{N}_{2}$ flow through $\mathrm{N}_{2}$ MFC. & Manual & Computer \\
\hline 19 & Control system pressure using HVs on manual bypass. & Manual & Field \\
\hline 20 & Monitor level in HP/HT stripper/separator. & Manual & Computer/Field \\
\hline 21 & Reset to normal operating mode on computer. & Manual & Computer \\
\hline 22 & $\begin{array}{l}\text { Verify cycling of top lock and bottom lock valves for all } \\
\text { separators/accumulators. }\end{array}$ & Manual & Computer \\
\hline 23 & Open HV upstream of PCV. & Manual & Field \\
\hline 24 & $\begin{array}{l}\text { Demonstrate control of system pressure through manual cycling } \\
\text { of PCV. }\end{array}$ & Manual & Computer \\
\hline 25 & Slowly close manual bypass valves. & Manual & Field \\
\hline 26 & $\begin{array}{l}\text { Establish normal system pressure and toggle to automatic } \\
\text { pressure control. }\end{array}$ & Manual & Computer \\
\hline 27 & Toggle all $\mathrm{H}_{2} \mathrm{AV}$ valves to open position. & Manual & Computer \\
\hline 28 & Slowly establish flows on $\mathrm{H}_{2}$ MFCs. & Manual & Computer \\
\hline 29 & Slowly reduce flow on $\mathrm{N}_{2}$ MFC. & Manual & Computer \\
\hline 30 & Toggle all $\mathrm{N}_{2} \mathrm{AV}$ valves to closed position. & Automatic & Computer \\
\hline 31 & $\begin{array}{l}\text { Increase preheater, reactor, and pressure vessel temperature SPs } \\
\text { to original values. }\end{array}$ & Manual & Computer \\
\hline 32 & Toggle slurry supply blocking valve to open position. & Automatic & Computer \\
\hline 33 & Toggle flush solvent supply blocking valve to closed position. & Automatic & Computer \\
\hline 34 & Resume normal operation. & & \\
\hline
\end{tabular}




\section{VALVE FAILURE RESPONSE}

\begin{tabular}{|c|c|c|c|c|c|c|c|c|c|c|c|c|c|c|c|c|}
\hline Area & Tag No. & Name & Actuation & Failure & Consequences & First Action & Second Action & Third Action & Fourth Action & Fifth Action & Sixth Action & Seventh Action & & & Comment & $\begin{array}{c}\text { Other } \\
\text { Possible } \\
\text { Action } \\
\end{array}$ \\
\hline 100 & AV 104 & $\begin{array}{c}\text { Hydrogen } \\
\text { accumulator/MFC } \\
\text { isolation }\end{array}$ & ATO & $\begin{array}{l}\text { Closes/iton't } \\
\text { open/leaks }\end{array}$ & $\begin{array}{l}\text { Loss of system } \mathrm{H}_{2} \\
\text { flow; reduction of } \\
\text { system pressure }\end{array}$ & $\begin{array}{l}\text { Replace slurry } \\
\text { flow with flush } \\
\text { solvent flow }\end{array}$ & $\begin{array}{l}\text { Replace } \mathrm{H}_{2} \text { flow } \\
\text { with } \mathrm{N}_{2}^{\text {purge at }} \\
\text { stripping } \mathrm{H}_{2} \mathrm{FCV}\end{array}$ & $\begin{array}{l}\text { Replace } \mathrm{H}_{2} \text { flow with } \\
\mathrm{N}_{2} \text { purge tat reaction } \mathrm{H}_{2} \\
\text { FCV }\end{array}$ & $\begin{array}{l}\text { Isolate blocking } \\
\text { valve and vent off } \\
\mathrm{H}_{2}\end{array}$ & $\begin{array}{l}\text { Repair, replace } \\
\text { (with spare), or } \\
\text { remove blocking } \\
\text { valve }\end{array}$ & $\begin{array}{l}\text { Begin transition } \\
\text { back to slurry } \\
\text { and } \mathrm{H}_{2} \text { flow }\end{array}$ & & & & & $\begin{array}{l}\text { Eliminate } \\
\text { valve }\end{array}$ \\
\hline 100 & AV 106 & $\begin{array}{c}\text { Nitrogen } \\
\text { accumulator/MFC } \\
\text { isolation }\end{array}$ & ATC & Leaks & $\begin{array}{l}\text { Loss of ability to } \\
\text { purge system with } \mathrm{N}_{2} \\
\text { during start-up or } \\
\text { emergency flush }\end{array}$ & $\begin{array}{l}\text { Replace slury } \\
\text { flow with flush } \\
\text { solvent flow }\end{array}$ & $\begin{array}{l}\text { Reduce preheater, } \\
\text { vessel, and reacetor } \\
\text { heater SPs }\end{array}$ & $\begin{array}{l}\text { Isolate blocking valve } \\
\text { and vent off } N_{2}\end{array}$ & $\begin{array}{l}\text { Repair, replace } \\
\text { (with spare), or } \\
\text { remove blocking } \\
\text { valve }\end{array}$ & $\begin{array}{l}\text { Begin transition to } \\
\text { solvent and } \mathrm{N}_{2} \text { flow }\end{array}$ & $\begin{array}{c}\text { Continue } \\
\text { following start- } \\
\text { up procedure }\end{array}$ & & & & $\begin{array}{l}\text { To be followed } \\
\text { when failure } \\
\text { during start-up } \\
\text { or purge }\end{array}$ & $\begin{array}{c}\text { Eliminate } \\
\text { valve }\end{array}$ \\
\hline 100 & AV 110 & $\begin{array}{l}\text { Reaction hydrogen } \\
\text { MFC - blocking }\end{array}$ & ATO & $\begin{array}{c}\text { Closes/won't } \\
\text { open/leaks }\end{array}$ & $\begin{array}{l}\text { Loss of } \mathrm{H}_{2} \text { flow to } \\
\text { reactor }\end{array}$ & $\begin{array}{l}\text { Replace slurry } \\
\text { flow with flush } \\
\text { solvent flow }\end{array}$ & $\begin{array}{l}\text { Replace stripping } \\
\mathrm{H}_{2} \text { flow with } \mathrm{N}_{2} \\
\text { purge flow }\end{array}$ & $\begin{array}{l}\text { Replace reaction } \mathrm{H}_{2} \\
\text { flow with } \mathrm{N}_{2} \text { purge } \\
\text { flow }\end{array}$ & $\begin{array}{l}\text { Close manual valve } \\
\text { downstream of } \\
\text { blocking valve }\end{array}$ & $\begin{array}{l}\text { Assess that manual } \\
\text { valve is sealed } \\
\text { before removal of } \\
\text { blocking valve }\end{array}$ & Vent off $\mathrm{H}_{2}$ & $\begin{array}{l}\text { Repair, replace } \\
\text { (with spare, or } \\
\text { remove blocking } \\
\text { valve }\end{array}$ & $\begin{array}{l}\text { Begin transition } \\
\text { back to slurry and } \\
\text { stripping } \mathrm{H}_{2} \text { flow }\end{array}$ & & & $\begin{array}{l}\text { Eliminate } \\
\text { valve }\end{array}$ \\
\hline 100 & AV 112 & $\begin{array}{l}\text { Purge nitrogen MFC- } \\
\text { blocking }\end{array}$ & ATC & Leaks & $\begin{array}{l}\text { Loss of ability to } \\
\text { purge reactor through } \\
\mathrm{N}_{2} \text { FCV during } \\
\text { emergency flush }\end{array}$ & $\begin{array}{l}\text { Replace slurry } \\
\text { flow with flush } \\
\text { solvent flow }\end{array}$ & $\begin{array}{l}\text { Replace stripping } \\
\mathrm{H}_{2} \text { flow with } \mathrm{N}_{2} \\
\text { purge flow }\end{array}$ & $\begin{array}{l}\text { Replace reaction } \mathrm{H}_{2} \\
\text { flow with } \mathrm{N}_{2} \text { purge } \\
\text { flow }\end{array}$ & $\begin{array}{l}\text { Close manual valve } \\
\text { downstream of } \\
\text { blocking valve }\end{array}$ & $\begin{array}{l}\text { Assess that manual } \\
\text { valve is sealed } \\
\text { before removal of } \\
\text { blocking valve }\end{array}$ & Vent off $\mathrm{N}_{2}$ & $\begin{array}{l}\text { Repair, replace } \\
\text { (with spare), or } \\
\text { remove blocking } \\
\text { valve }\end{array}$ & $\begin{array}{l}\text { Begin transition to } \\
\text { solvent and } \mathrm{N}_{\text {f }} \text { flow }\end{array}$ & $\begin{array}{c}\text { Continue } \\
\text { following start-up } \\
\text { procedure }\end{array}$ & $\begin{array}{l}\text { To be followed } \\
\text { when failure } \\
\text { during start-up } \\
\text { or purge }\end{array}$ & $\begin{array}{c}\text { Eliminate } \\
\text { valve }\end{array}$ \\
\hline 100 & AV 114 & $\begin{array}{l}\text { Hydrogen/nitrogen } \\
\text { isolation }\end{array}$ & ATO & $\begin{array}{c}\text { Closes/won't } \\
\text { open/leaks }\end{array}$ & $\begin{array}{c}\text { Loss of ability to } \\
\text { purge through } \mathrm{H}_{2} \\
\text { FCVs during statt-up } \\
\text { or emergency flush }\end{array}$ & $\begin{array}{l}\text { Replace slurry } \\
\text { flow with flush } \\
\text { solvent flow }\end{array}$ & $\begin{array}{l}\text { Reduce preheater, } \\
\text { vessel, and reactor } \\
\text { heater SPs }\end{array}$ & $\begin{array}{c}\text { Initiate } \mathrm{N}_{\text {f flow }} \\
\text { through } \mathrm{N}_{2} \text { purge FCV }\end{array}$ & Assess status of test & $\begin{array}{l}\text { If conditions allow, } \\
\text { isolate blocking } \\
\text { valve and vent off }\end{array}$ & $\begin{array}{l}\text { Repair, replace } \\
\text { (with spare), or } \\
\text { remove blocking } \\
\text { valve }\end{array}$ & $\begin{array}{l}\text { Begin transition to } \\
\text { solvent and } \mathrm{N}_{2} \text { flow }\end{array}$ & $\begin{array}{l}\text { Continue following } \\
\text { start-up procedure }\end{array}$ & & & $\begin{array}{l}\text { Eliminate } \\
\text { valve }\end{array}$ \\
\hline 200 & AV 202 & Slurry cutoff & ATO & $\begin{array}{c}\begin{array}{c}\text { Closes/won't } \\
\text { open/leaks }\end{array} \\
\text { of }\end{array}$ & $\begin{array}{l}\text { Loss of slurry flow to } \\
\text { system }\end{array}$ & $\begin{array}{c}\text { Open solvent } \\
\text { flush cutoff valve } \\
\text { to flush HP } \\
\text { slurry pump }\end{array}$ & $\begin{array}{l}\text { Replace } \mathrm{H}_{2} \text { flow } \\
\text { with } \mathrm{N}_{2} \text { purge at } \\
\text { stripping } \mathrm{H}_{2} \mathrm{FCV}\end{array}$ & $\begin{array}{l}\text { Replace } \mathrm{H}_{2} \text { flow with } \\
\mathrm{N}_{2} \text { purge tat reaction } \mathrm{H}_{2} \\
\text { FCV }\end{array}$ & $\begin{array}{c}\text { Transition to HP } \\
\text { solvent flush pump } \\
\text { operation }\end{array}$ & $\begin{array}{c}\text { Close HP slurry } \\
\text { pump outlet valve }\end{array}$ & $\begin{array}{c}\text { Close manual } \\
\text { valve upstream } \\
\text { of blocking valve }\end{array}$ & $\begin{array}{l}\text { Repair, replace } \\
\text { (with spare), or } \\
\text { remove blocking } \\
\text { valve }\end{array}$ & $\begin{array}{l}\text { Begin transition to } \\
\text { solvent and } \mathrm{N}_{2} \text { flow }\end{array}$ & $\begin{array}{l}\text { Continue } \\
\text { following start-up } \\
\text { procedure }\end{array}$ & & \\
\hline 200 & AV 204 & Solvent flush cutoff & ATC & Leaks & $\begin{array}{l}\text { Loss of ability to flush } \\
\text { HP slurry pump with } \\
\text { solvent during } \\
\text { emergency }\end{array}$ & $\begin{array}{l}\text { Initiate solvent } \\
\text { flow through HP } \\
\text { flush solvent } \\
\text { pump }\end{array}$ & $\begin{array}{l}\text { Replace } \mathrm{H}_{2} \text { flow } \\
\text { with } \mathrm{N}_{2} \text { purge at } \\
\text { stripping } \mathrm{H}_{2} \mathrm{FCV}\end{array}$ & $\begin{array}{l}\text { Replace } \mathrm{H}_{2} \text { flow with } \\
\mathrm{N}_{2} \text { purge at reaction } \mathrm{H}_{2} \\
\text { FCV }\end{array}$ & $\begin{array}{l}\text { Close HP slurry } \\
\text { pump outlet valve }\end{array}$ & $\begin{array}{c}\text { Close manual valve } \\
\text { upstream of } \\
\text { blocking valve }\end{array}$ & $\begin{array}{l}\text { Repair, replace } \\
\text { (with spare), or } \\
\text { remove blocking } \\
\text { valve }\end{array}$ & $\begin{array}{l}\text { Begin transition to } \\
\text { solvent and } \mathrm{N}_{2} \text { flow }\end{array}$ & $\begin{array}{l}\text { Continue following } \\
\text { start-up procedure }\end{array}$ & & & \\
\hline 200 & AV 206 & Solvent flush cutoff & ATC & $\begin{array}{l}\text { Opens while } \\
\text { feeding slurry }\end{array}$ & $\begin{array}{l}\text { Possible replacement } \\
\text { of slurry with solvent }\end{array}$ & $\begin{array}{l}\text { Close manual } \\
\text { hand valve } \\
\text { upstream of } \\
\text { automated valve }\end{array}$ & & & & & & & & & & \\
\hline 400 & AV 410 & $\begin{array}{l}\text { Bottoms stripper } \\
\text { accumulator - top } \\
\text { lock }\end{array}$ & ATO & $\begin{array}{l}\text { Closes/won't } \\
\text { open/leaks }\end{array}$ & $\begin{array}{l}\text { Loss of ability to } \\
\text { remove bottoms from } \\
\text { BSA vessel }\end{array}$ & $\begin{array}{l}\text { Close manual } \\
\text { valve upstream } \\
\text { of BSA vessel }\end{array}$ & $\begin{array}{l}\text { Assess need to } \\
\text { replace slury with } \\
\text { solvent flush (large }\end{array}$ & $\begin{array}{l}\text { Complete repair or } \\
\text { replacement of valve if } \\
\text { assessed to require }\end{array}$ & $\begin{array}{c}\text { If shutdown } \\
\text { required, follow } \\
\text { normal shutdown }\end{array}$ & $\begin{array}{c}\text { Recover warm } \\
\text { liquids from bottom } \\
\text { of BSA vessel after }\end{array}$ & & & & & & \\
\hline 400 & AV 412 & $\begin{array}{l}\text { Bottoms stripper } \\
\text { accumulator - bottom } \\
\text { lock }\end{array}$ & АTO & $\begin{array}{l}\text { Closes/won't } \\
\text { open/leaks }\end{array}$ & & & $\begin{array}{l}\text { volume of BSA } \\
\text { may allow longer } \\
\text { time for assessment } \\
\text { and repair) }\end{array}$ & $\begin{array}{l}\text { short time period and } \\
\text { continue with } \\
\text { operation }\end{array}$ & $\begin{array}{l}\text { including solvent } \\
\text { flush to remove } \\
\text { solidf from reactor } \\
\text { and HP/HT vessel }\end{array}$ & $\begin{array}{l}\text { sysstem } \\
\text { depressurization }\end{array}$ & & & & & & \\
\hline 400 & AV 414 & $\begin{array}{l}\text { Condensate } \\
\text { accumulator - top } \\
\text { lock valve }\end{array}$ & ATO & $\begin{array}{l}\text { Closes/won't } \\
\text { open/leaks }\end{array}$ & $\begin{array}{l}\text { Loss of ability to } \\
\text { remove liquidds from } \\
\text { condensate } \\
\text { accumblato ressel }\end{array}$ & $\begin{array}{c}\text { Close manual } \\
\text { valve upstream } \\
\text { of condensate } \\
\text { atcumylater }\end{array}$ & $\begin{array}{l}\text { Assess need to } \\
\text { replace sulury with } \\
\text { solvent flush (large } \\
\text { volume of }\end{array}$ & $\begin{array}{l}\text { Completere repair or } \\
\text { replacement of valve if } \\
\text { assessed to require } \\
\text { short time neriod anat }\end{array}$ & $\begin{array}{l}\text { If shutdown } \\
\text { required, follow } \\
\text { normal shutdown } \\
\text { inclding colvent }\end{array}$ & $\begin{array}{l}\text { Recover liquids } \\
\text { from bottom of } \\
\text { condensate } \\
\text { contentarer }\end{array}$ & & & & & & \\
\hline 400 & AV 416 & $\begin{array}{l}\text { Condensate } \\
\text { accumulator - bottom } \\
\text { lock valve }\end{array}$ & АТО & $\begin{array}{c}\text { Closes/won't } \\
\text { open/leaks }\end{array}$ & & $\begin{array}{l}\text { accumulator } \\
\text { vessel letdown } \\
\text { valves }\end{array}$ & $\begin{array}{l}\text { Volume of } \\
\text { accumulator may } \\
\text { allow longer time } \\
\text { for assessment and } \\
\text { repair) }\end{array}$ & $\begin{array}{l}\text { Short tume period and } \\
\text { continue with } \\
\text { operation }\end{array}$ & $\begin{array}{l}\text { Including govivent } \\
\text { flush to remove } \\
\text { solids from reactor } \\
\text { and } \mathrm{HP} / \mathrm{HT} \text { vessel }\end{array}$ & $\begin{array}{c}\text { accumulator after } \\
\text { system } \\
\text { depressurization }\end{array}$ & & & & & & \\
\hline 400 & PCV 418 & $\begin{array}{l}\text { Pressure Control } \\
\text { Valye } 418\end{array}$ & ATC & Opens/leaks & 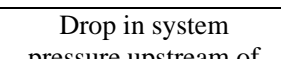 & $\begin{array}{c}\text { Close manual } \\
\text { valyes unstream }\end{array}$ & $\begin{array}{l}\text { Open upstream } \\
\text { pdlor dosnctsanm }\end{array}$ & Continue with system & Assess ability to & $\begin{array}{l}\text { If valve not } \\
\text {. }\end{array}$ & & & & & & \\
\hline 400 & PCV 420 & $\begin{array}{l}\text { Pressure Control } \\
\text { Valve } 420\end{array}$ & ATC & Opens/leaks & $\begin{array}{l}\text { pressure control valves } \\
\text { and increase in } \\
\text { downstream system } \\
\text { pressure (downstream } \\
\text { vessels are protected } \\
\text { with safety reliefs) }\end{array}$ & $\begin{array}{l}\text { and downstream } \\
\text { of affected } \\
\text { control valve }\end{array}$ & $\begin{array}{l}\text { manual valves on } \\
\text { spare control valve }\end{array}$ & control valve & affe & $\begin{array}{l}\text { continuing } \\
\text { operation without } \\
\text { backup pressure } \\
\text { control }\end{array}$ & & & & & & \\
\hline
\end{tabular}




\section{APPENDIX B}

\section{PROCESS DEVELOPMENT UNIT STANDARD OPERATING PROCEDURE \\ AS OF 25 JULY 2012}




\section{DIRECT COAL LIQUEFACTION PROCESS DEVELOPMENT UNIT}

\section{Standard Operating Procedure (SOP)}

Version 3.2

Prepared by:

Mark A. Musich

Energy \& Environmental Research Center

University of North Dakota

15 North 23rd Street, Stop 9018

Grand Forks, ND 58202-9018 


\section{TABLE OF CONTENTS}

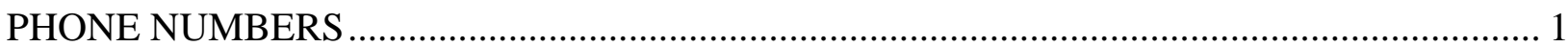

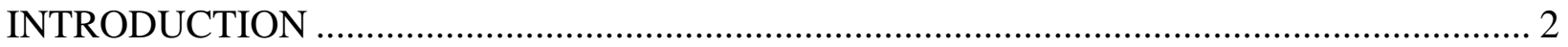

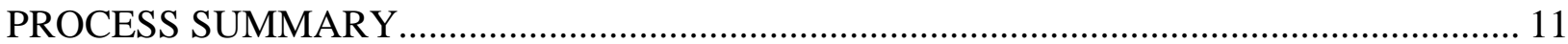

Step 1 - Target Coal Preparation ......................................................................................... 11

Step 2 - Preparation of Vacuum Gas Oil (VGO) ................................................................. 11

Step 3 - Liquefaction (production of middle distillate) ………………………………….... 12

DCL System Products ..................................................................................................... 12

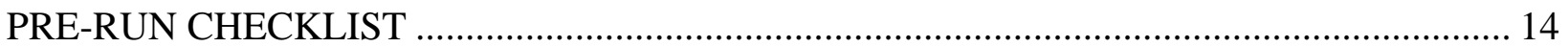

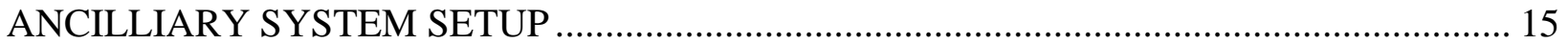

SYSTEM LEAK-CHECK WITH HELIUM/NITROGEN BLEND ............................................ 16

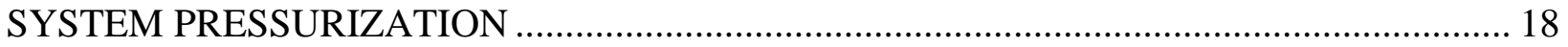

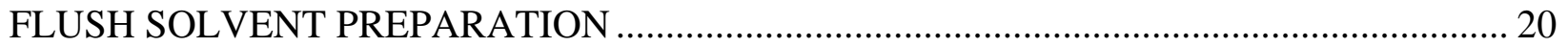

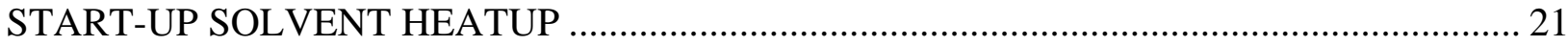

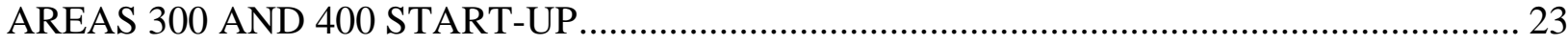

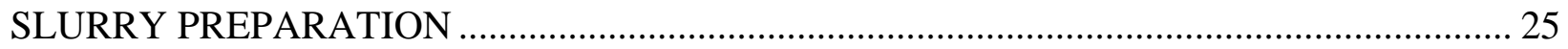

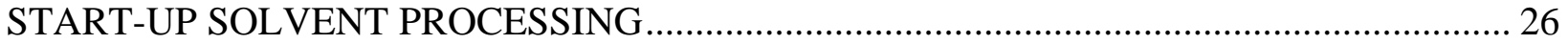

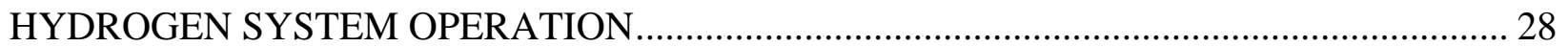

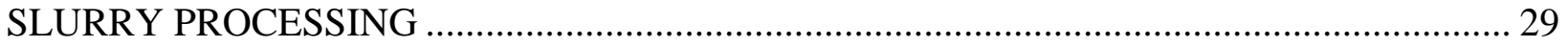

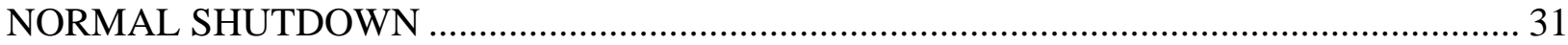

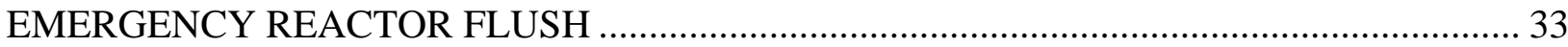

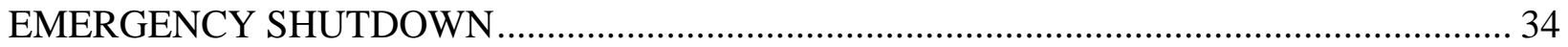

LOSS OF SOLENOID ACTIVATION GAS PRESSURE ….......................................................... 35

PROCESS CONTROL COMPUTER SCREEN SHOTS................................................Appendix A

START-UP VALVE POSITIONS ............................................................................ Appendix B 


\section{PHONE NUMBERS}

\section{Emergency}

EERC Facility/Safety Coordinator

Ken Grohs

701-777-5137

Grand Forks Fire Department

9-911

\section{Project Personnel}

Ramesh Sharma

Project Manager

701-777-5194

Ted Aulich

Malhar Khambete

Sr. Research Manager

701-777-2982

Mark Musich

Research Engineer

701-777-5007

Jim Tibbetts

Research Engineer

701-777-5263

EERC Reception Desk

Research Engineer

701-777-5282

701-777-5000

Facilities Maintenance

701-777-5199

Instrumentation Shop

$701-777-5110$

Machine Shop

$701-777-5140$

National Center for Hydrogen Technology Control Room

701-777-5388 


\section{INTRODUCTION}

With guidance from Accelergy, the Energy \& Environmental Research Center (EERC) designed, fabricated and installed a 50-pound/day (dry coal input basis) direct coal liquefaction (DCL) reactor system at EERC. The system is installed on two floors of the EERC National Center for Hydrogen Technology (NCHT) building. This building is equipped with necessary infrastructure including fire alarm and suppression systems, hazardous gas alarm, ventilation system, process gas flare, air and nitrogen (high and low pressure).

The intended uses of the DCL system are to 1) generally validate results of bench-scale DCL tests conducted to convert coal to liquids suitable for upgrading to jet and other transportation fuels, and 2) produce coal liquids for upgrading to large (up to 25-gallon) fuel samples for evaluation by the U.S. Air Force Research Laboratory (AFRL) at Wright Patterson Air Force Base, Dayton, Ohio. The DCL system is not intended to generate material balance or scalable data.

The purpose of this manual is to familiarize operators with the overall DCL process, process components, and process operation methodology. The various steps involved in the overall DCL process are shown in Figure 1. The DCL system will operate in a semicontinuous mode and comprises two primary subsystems:

1 The reactor system (Figures 2-7), comprising the primary process equipment needed to convert coal to a raw coal liquids product.

2 The distillation system (Figure 8), which will be used to separate the raw coal liquids product into vacuum gas oil (VGO), naphtha, water, and "middle distillate" fractions. The middle distillate fraction will be upgraded (in a separate facility), the naphtha fraction will be upgraded and/or otherwise utilized, and the VGO fraction will be recycled. The distillation will be installed in a large hood in the NCHT building near the DCL reactor system.

The DCL system comprises the following "process areas":

- Area 100 - hydrogen/nitrogen supply and delivery

- Area 200 - feed slurry/solvent preparation and delivery

- Area 300 - preheaters, sand-bath heater, and reactors

- Area 400 high pressure (HP) - product stripper and condensate separator

- Area 400 low pressure (LP) - bottoms and condensate recovery and collection

Appendix A contains computer screen shots of the PC-based process control and datalogging system. Appendix B presents the valve start-up positions. 


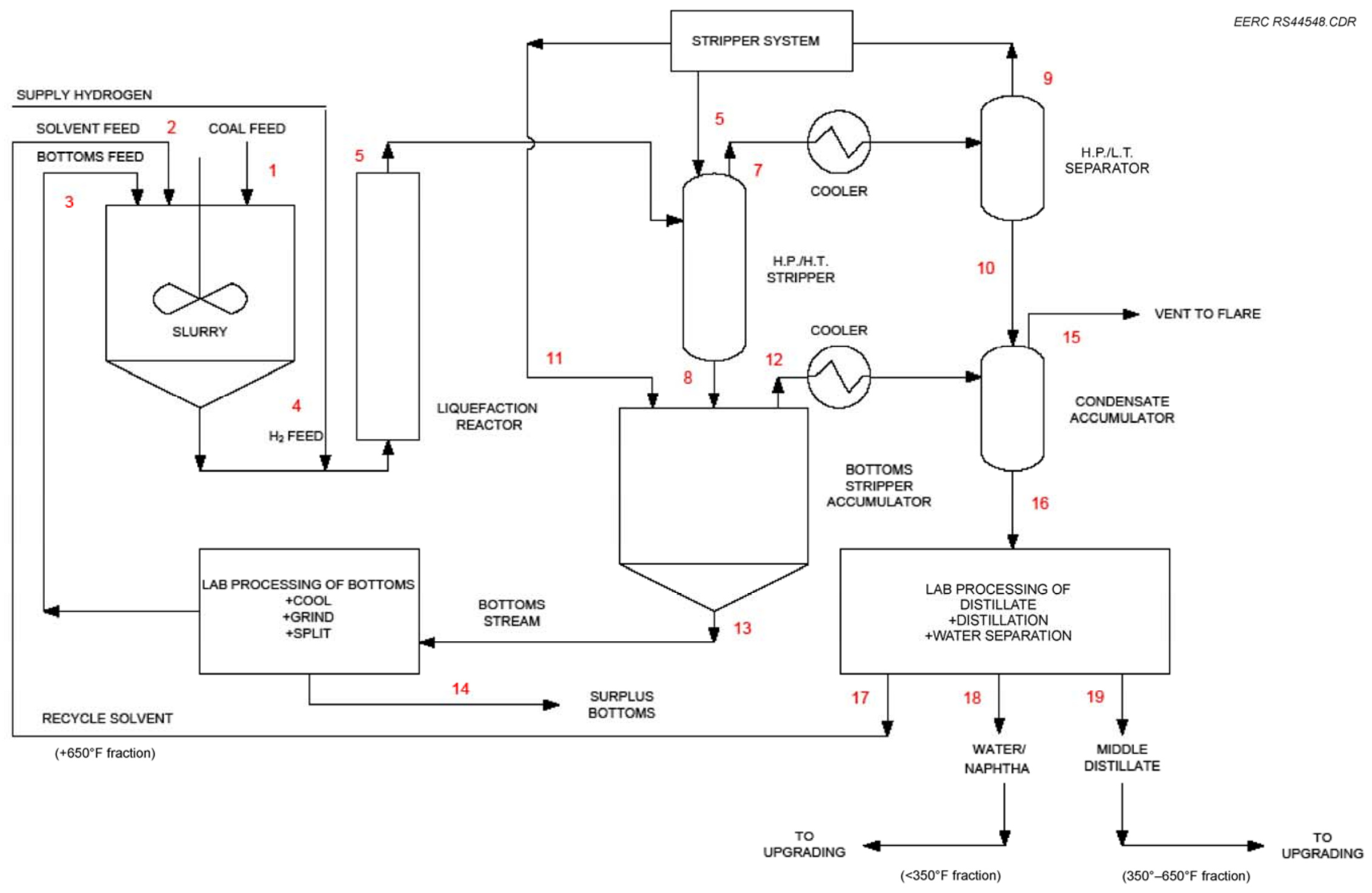

Figure 1. DCL process flow diagram. 


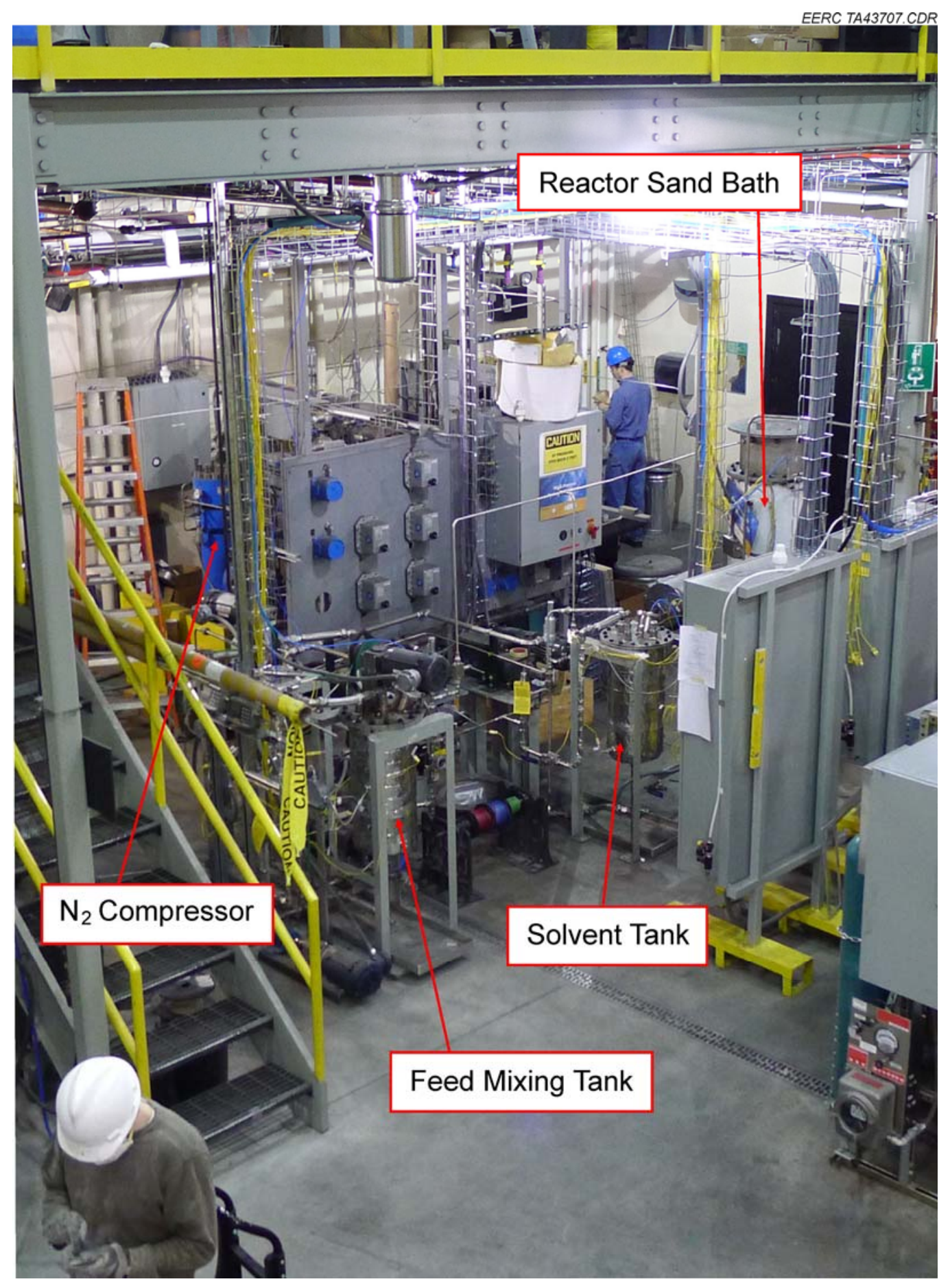

Figure 2. First-floor view of DCL reactor system. 


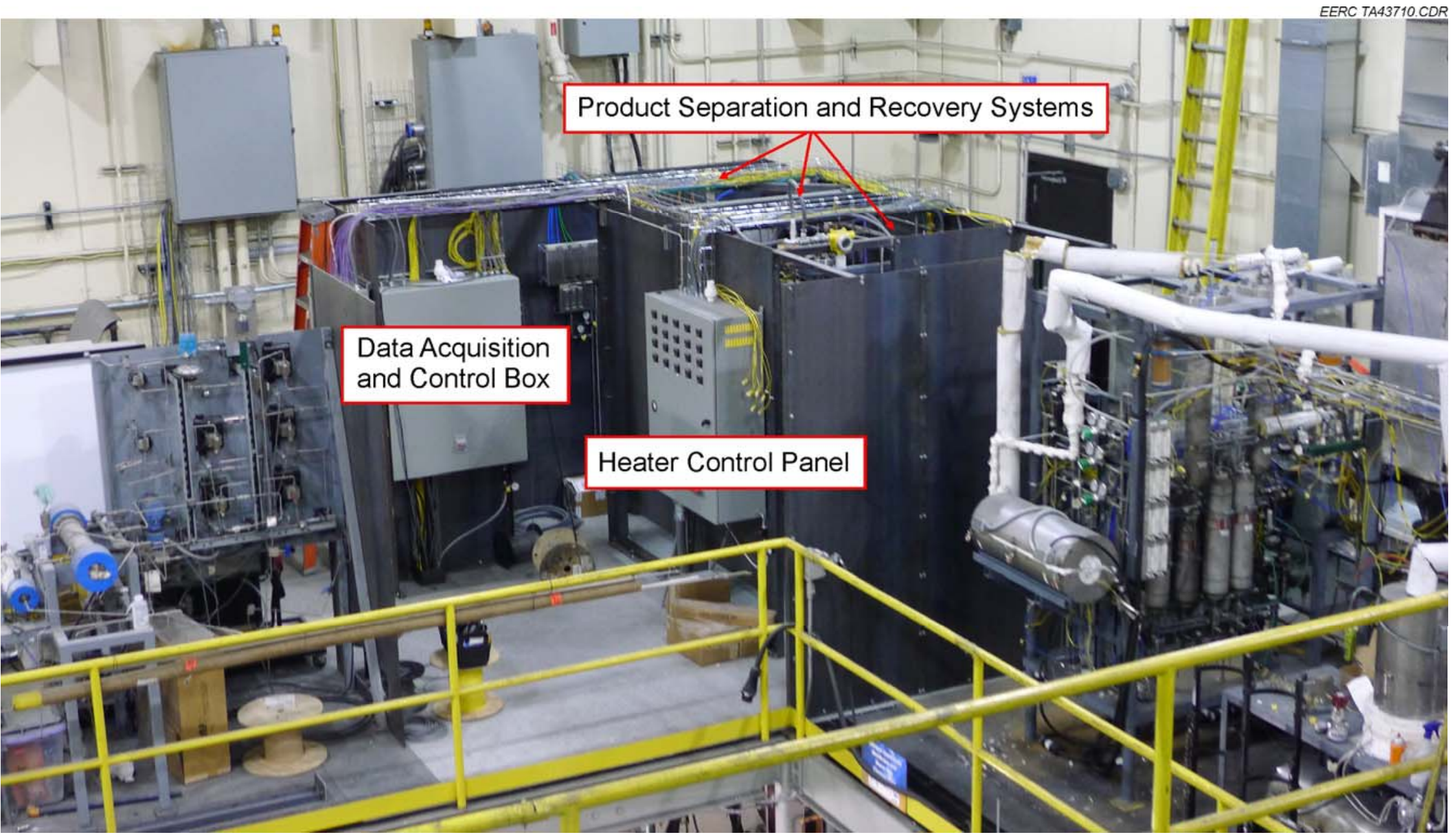

Figure 3. Second-floor view of DCL reactor system. 


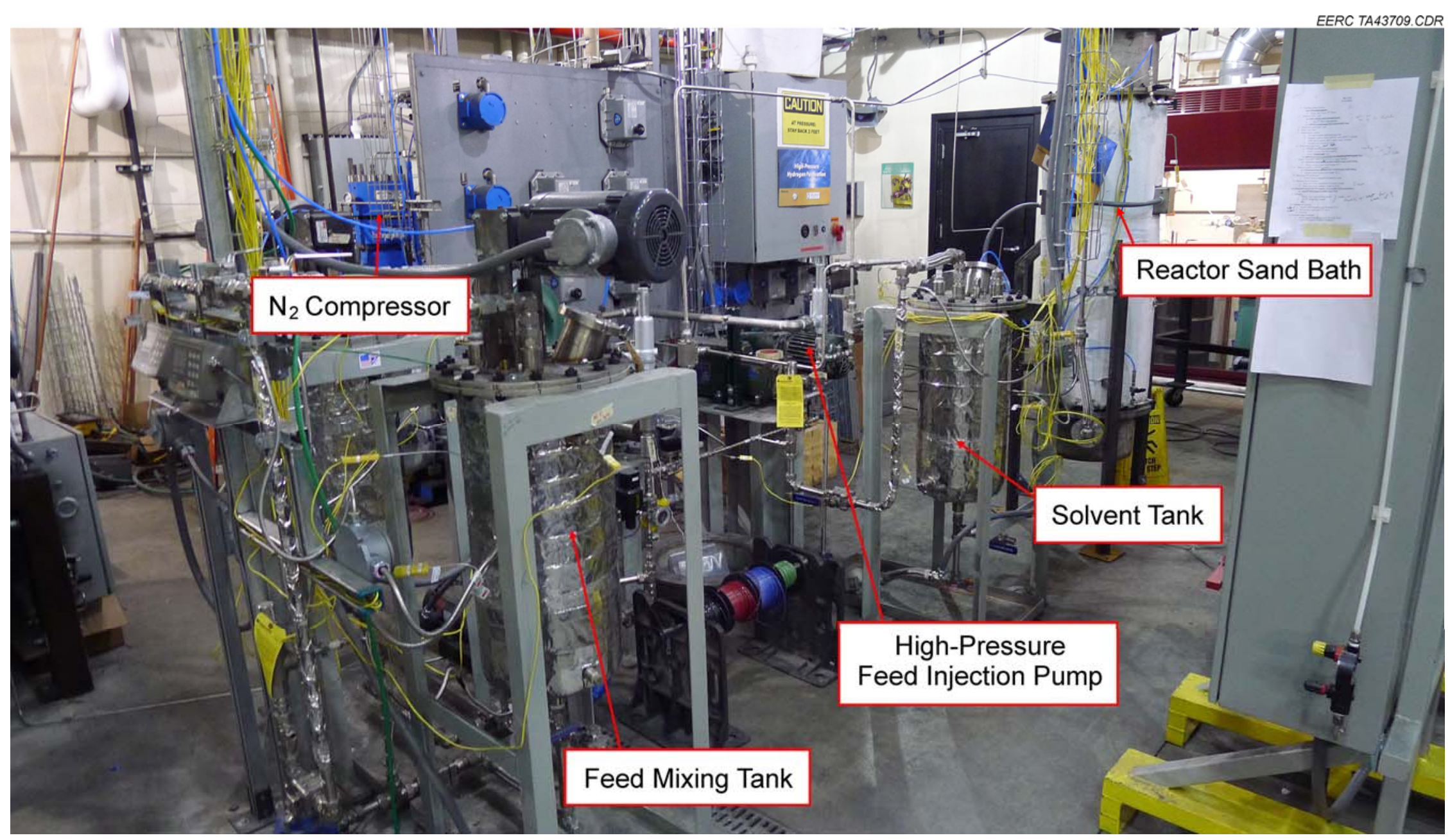

Figure 4. Close-up of prereactor feed preparation and injection systems. 


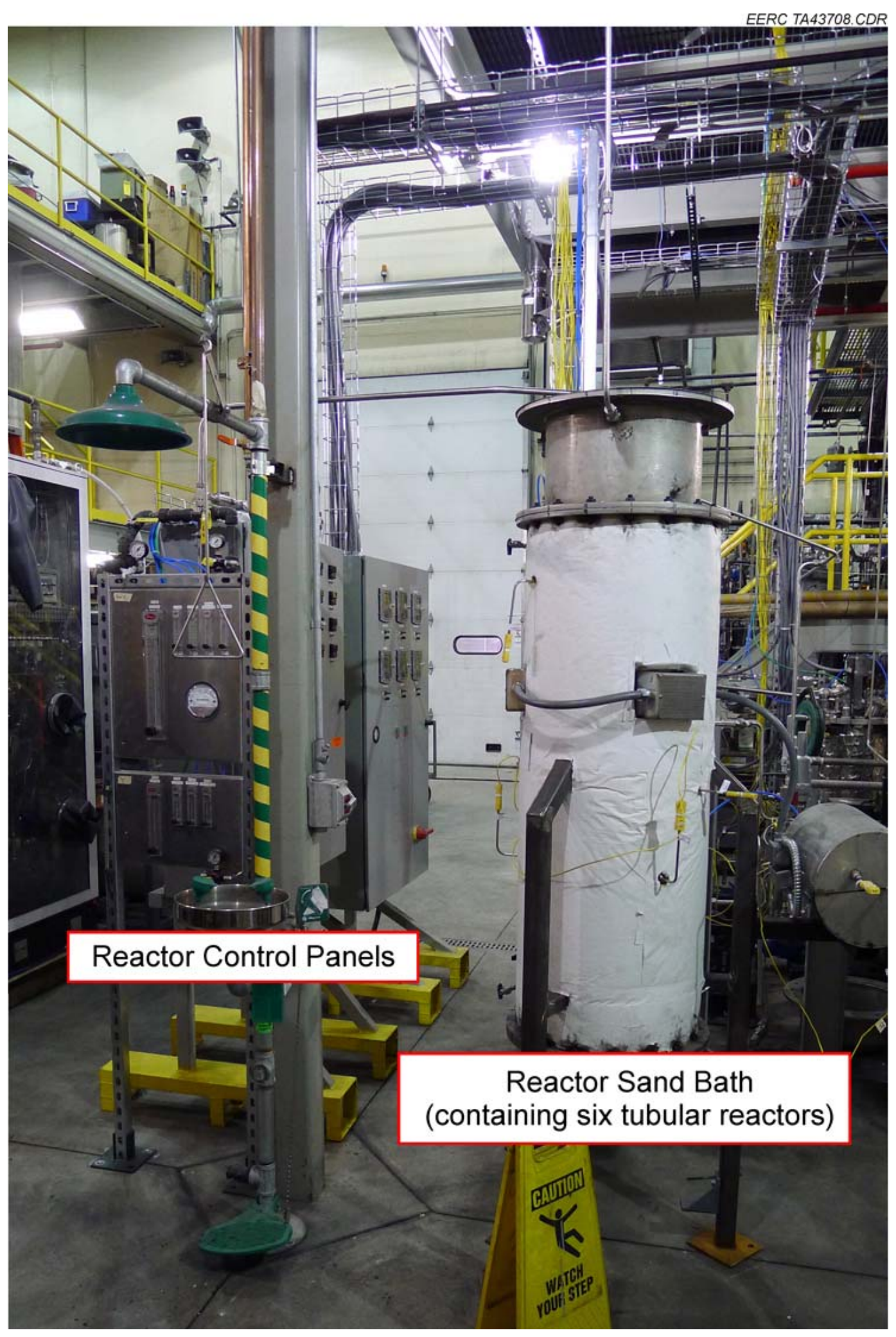

Figure 5. Close-up of DCL reactor sandbath. 
$\infty$

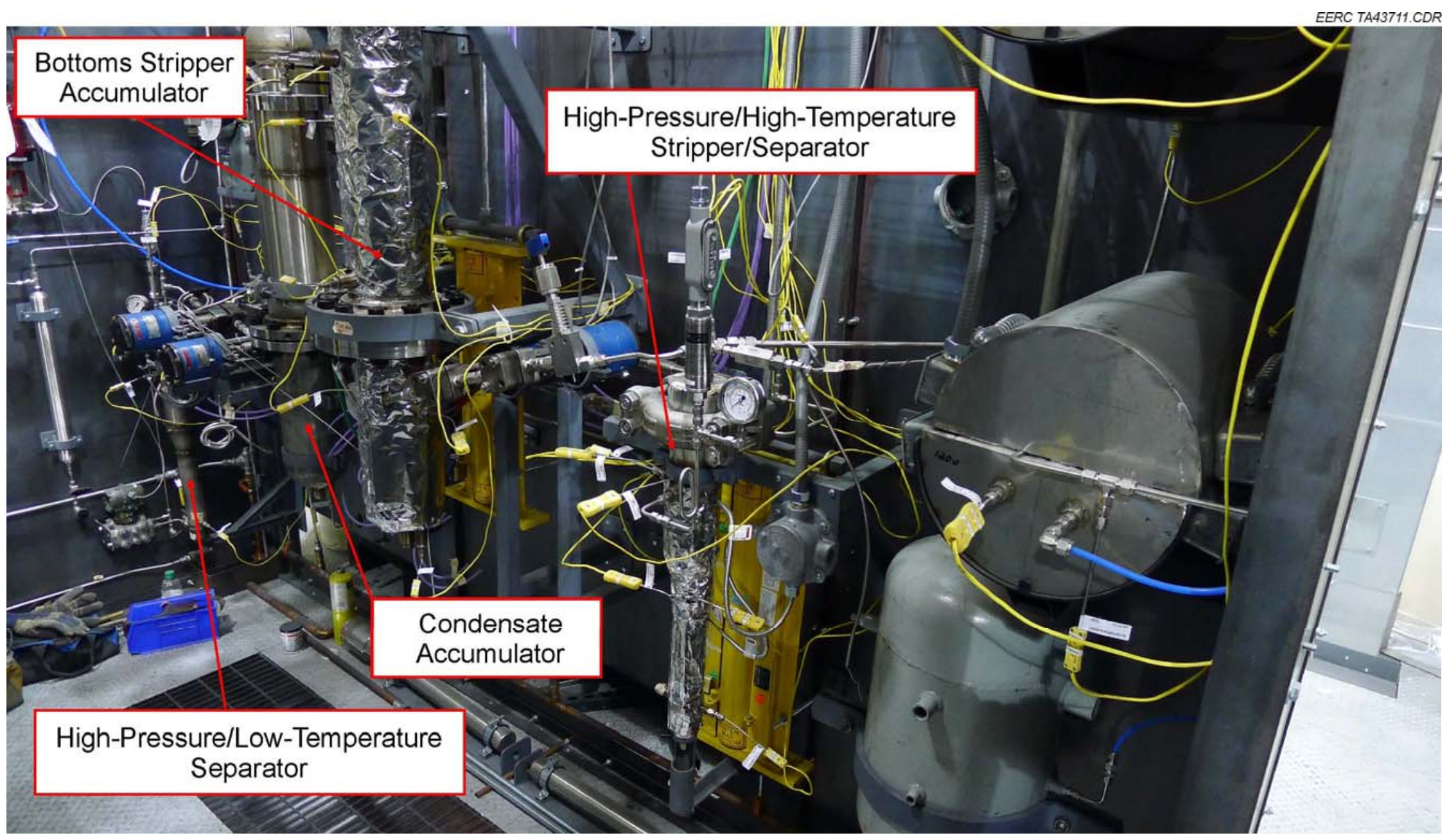

Figure 6. Close-up of product separation and accumulation systems. 


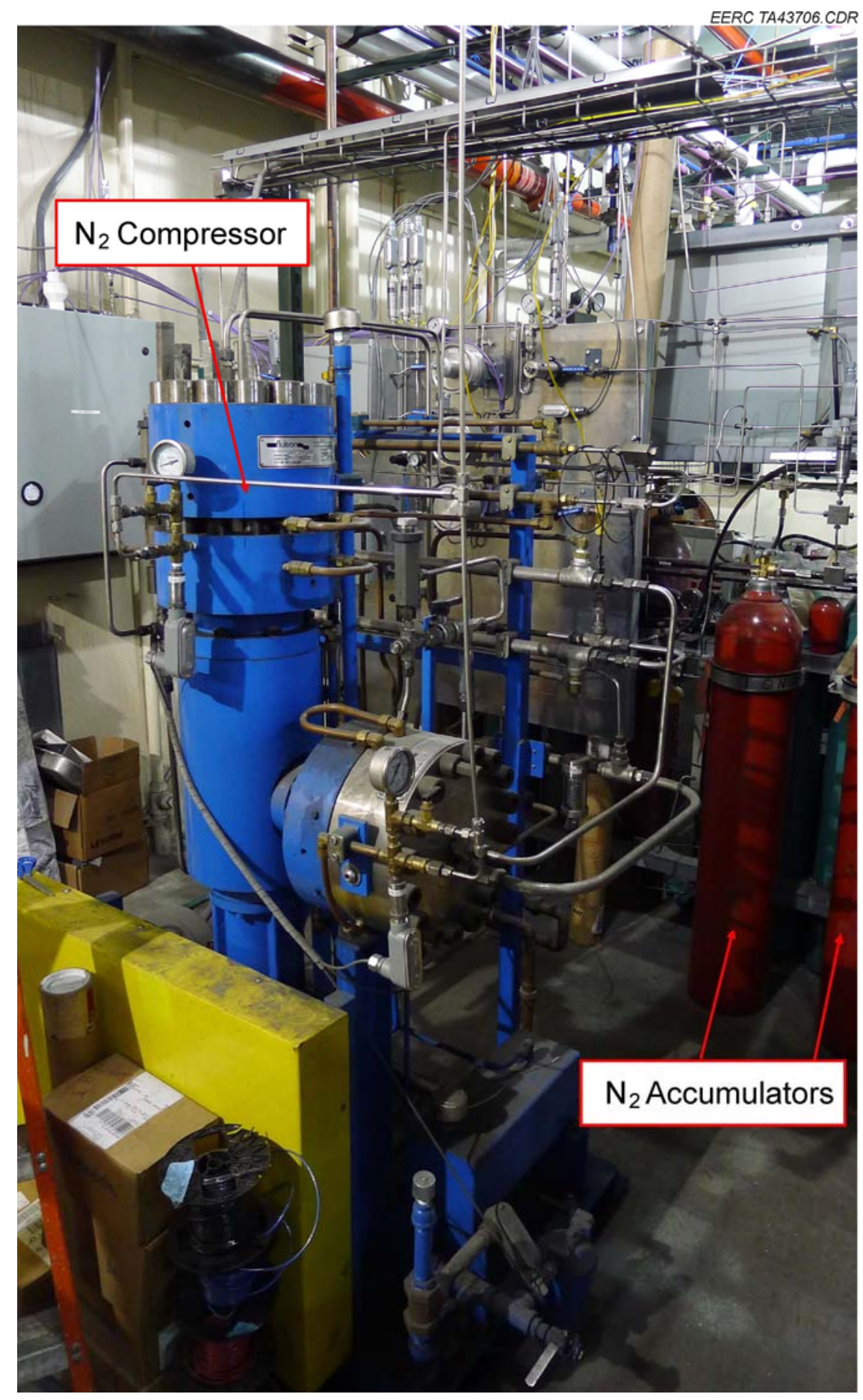

Figure 7. Nitrogen compressor system. 


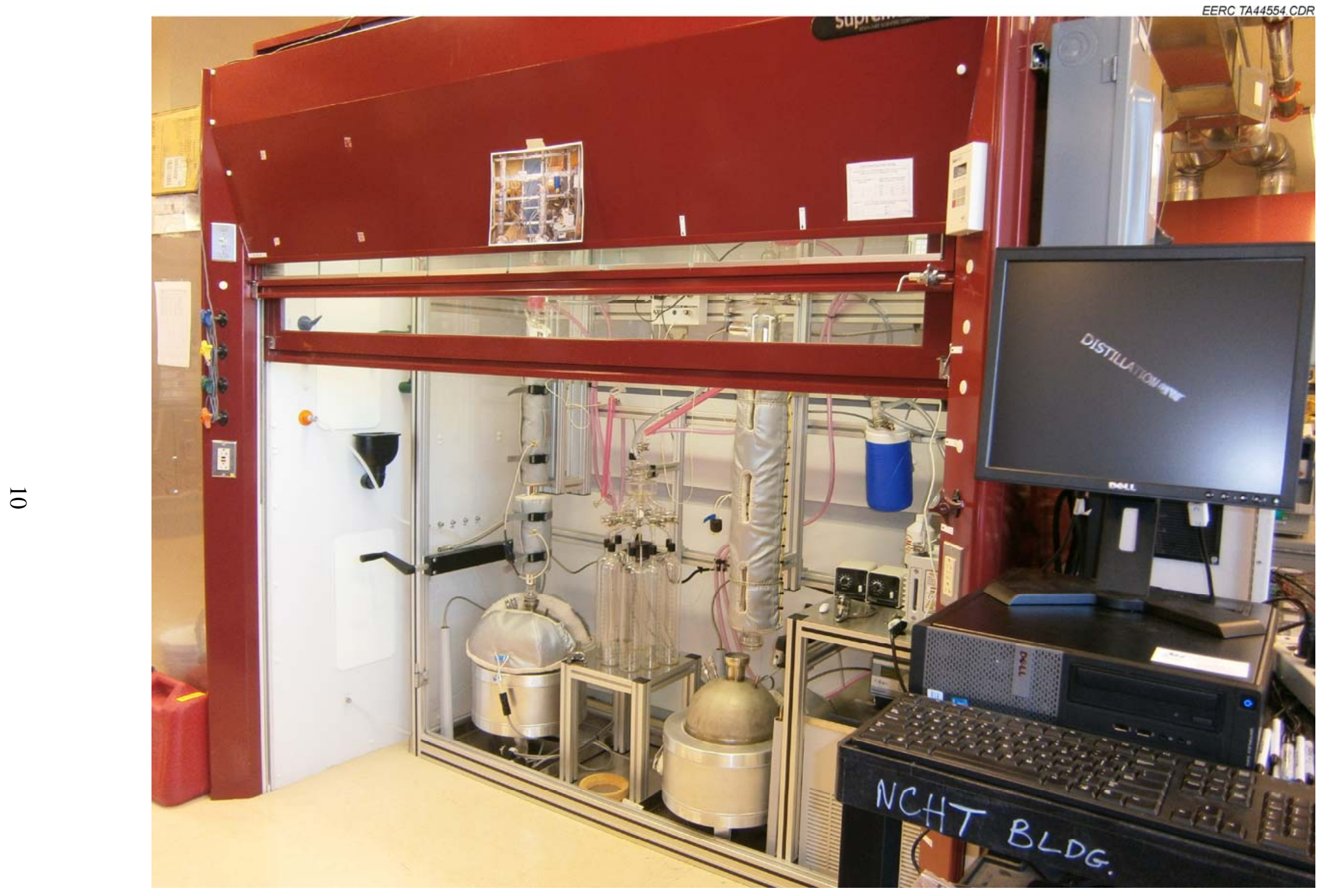

Figure 8. P9600 Spinning band distillation system. 


\section{PROCESS SUMMARY}

Generating raw coal liquids from a target coal is a three-step procedure comprising 1) target coal preparation, 2) preparation of target coal-derived VGO and vacuum bottoms in sufficient quantities (50 pounds each) to initiate a liquefaction run, and 3) liquefaction for production of target coal raw coal liquids. Procedures for the three steps are described below.

\section{Step 1 - Target Coal Preparation}

It is important that as-received and prepped coals are stored under nitrogen in airtight containers. Since the as-received coal is in the form of large lumps and contains a significant amount of water (5\%-40\%) depending on the coal type, it is necessary to predry the coal to save energy needed to heat water in the coal. The lump coal will be floor-dried to remove any surface moisture and any easily volatilized inherent moisture. Also, to achieve a high degree of conversion, the coal needs to be pulverized to enable optimal coal-solvent-catalyst contact during liquefaction. Thus, the as-received coal is pulverized and sized using a 100-mesh screen in an automated classifier, collecting all coal passing through the screen. The pulverized coal will then be fed into a rotary kiln at $110^{\circ} \mathrm{C}$ under nitrogen flow until the water content of the coal is about $1 \%$. The dried coal is then collected and stored under nitrogen in airtight containers prior to undergoing liquefaction.

\section{Step 2 - Preparation of Vacuum Gas Oil (VGO)}

Initial processing is designed to generate test coal-derived VGO and vacuum bottoms. The bottoms will be generated in the main reactor system and the VGO (recycle solvent) will be generated in the distillation unit. Initially, a start-up slurry consisting of coal, catalyst (100 ppm in coal-catalyst mix), and hydrogenated anthracene oil (1.6 solvent/coal mass ratio) will be premixed in a slurry mixing tank (feed mixing tank, Figure 4), and then transferred to a slurry feed tank with the help of a pump. The start-up slurry will then be fed into the tubular reactor housed in a fluidized bed-sand bath at a predetermined rate using a high-pressure pump (Figure 4). The volatile products will be condensed to form a liquid using a series of condensers, and remaining slurry (vacuum bottoms) will be collected and transferred to a freezer for storage. The frozen slurry will be pulverized to -100-mesh size and transferred into the mixing tank for recycle. The uncondensed gases will pass through a scrubber for removal of acidic gases, and the remaining gas will be sent to the flare system. The condensed liquid will be collected every 6 hours, transferred to a distillation unit located near the DCL system, and batch distilled to yield about 4.2 liters of VGO and 3 liters of distillate comprising naphtha, water, and a "middle distillate cut" (which will necessarily contain a significant amount of start-up slurry-derived coal tar distillate). The VGO obtained from distillation (along with the previously collected vacuum bottoms) will be used for recycle.

The purpose of the initial processing is to generate enough test coal-derived vacuum bottoms and VGO to start the liquefaction process, and thereafter the process will be selfsustaining and generate bottoms and VGO on a continuous basis. After sufficient amounts of vacuum bottoms and VGO needed to initiate the liquefaction process are produced, further processing will be conducted to produce test coal-derived raw middle distillate for upgrading to 
jet fuel or other fuel. Middle distillate upgrading will be conducted in a separate EERC hydroprocessing facility.

The gaseous, liquid, and solid products formed during liquefaction are potentially hazardous and must be handled, stored, and disposed of using care and appropriate skin and eye protection.

\section{Step 3 - Liquefaction (production of middle distillate)}

After generating sufficient quantities of test coal-derived solvent VGO and vacuum bottoms, the liquefaction of test coal will be conducted to generate distillate fuel referred to as middle distillate for upgrading to produce synthetic fuels. The standard operating conditions that will be frequently used are as follows:

- Temperature $=450^{\circ} \mathrm{C}$

- Residence time $=60$ minutes

- Pressure $=2500 \mathrm{psi}$

During liquefaction processing of test coal, vacuum bottoms ground to -100 mesh, solvent/VGO, and catalyst will be transferred to the slurry tank. The overall process involves feeding slurry consisting of an approximate 1/1/1 mixture of dried coal (2 pounds), coal-derived solvent/VGO (1.8 pounds), vacuum bottoms (1.8 pounds) and 100-300 ppm catalyst per hour to the reactor. A constant pressure of 2500 psig will be maintained through use of a pressure control valve and constant flow of hydrogen. Operating conditions can be varied depending on the composition and reactivity of the material that will be processed. The temperature can be lowered or raised to $500^{\circ} \mathrm{C}$ with automated controls. The 60 -minute residence time is based on a 2-pound/hour dry coal input rate with six 39-inch reactor tubes installed. This residence time can be changed by either adding or subtracting tubes or by changing the overall flow rate of the system.

Liquefaction will utilize the same procedures described above for Step 2 - Preparation of VGO, with the exception that the initial solvent charge to be utilized will comprise Step 1-the prepared VGO material rather than the hydrogenated anthracene oil.

\section{System Products}

Appendix C describes a theoretical material balance around the DCL system operating with an input of 2 pounds of air-dried coal an hour. The solvent (VGO) and vacuum bottoms will be recycled. The amounts and composition of the products will be dependent on the test coal used. Overall, the DCL system will produce following products:

1. Gases: The gas yield will be about 0.13 pounds/hour or $8 \mathrm{wt} \%$ of dry ash-free (daf) coal. The gases produced will include $\mathrm{H}_{2}, \mathrm{H}_{2} \mathrm{~S}, \mathrm{NH}_{3}, \mathrm{CO}, \mathrm{CO}_{2}$, methane, ethane, propane, and butane. The gas will be routed to a flare system for destruction. 
2. Liquids: Two types of liquids, primarily aqueous and oils will be produced by the DCL system.

- Aqueous product yield will be about 0.18 pounds/hour or $10 \mathrm{wt} \%$ of daf coal added. This fraction will contain small amounts of alcohols, ketones, phenols, mercaptans, and hydrocarbons dissolved in water. Therefore, wastewaters are potential hazards and need to be disposed of according to U.S. Environmental Protection Agency guidelines.

- Oils will be taken to a semiautomatic distillation unit for fractional distillation (refer to distillation manual) to produce the following fractions:

1) Naphtha (room temperature- $\left.350^{\circ} \mathrm{F}\right)(0.14$ pounds/hour or $8.0 \mathrm{wt} \%$ of daf coal used) to be reformed or upgraded to produce a gasoline blendstock.

2) Middle distillate $\left(350^{\circ}-650^{\circ} \mathrm{F}\right)(0.78$ pounds/hour or $44 \mathrm{wt} \%$ of daf coal added) to be upgraded to produce fuels.

3) Heavy oil $\left(>650^{\circ} \mathrm{F}\right)$ to be recycled.

3. Solids (vacuum bottoms, including ash) yield is expected to be 0.60 pounds/hour, and comprise about 0.36 pounds/hour (30 wt\% of daf coal) organic material and 0.24 pounds/hour ash. The tarlike vacuum bottoms product, which comprises the residue remaining after distillation of the liquefaction slurry (with a boiling point of $>1000^{\circ} \mathrm{F}$ ) will be recycled.

The distillate oils will be stored in a freezer until they are ready for upgrading to produce finished fuels. The finished fuels will be packaged under nitrogen and stored in a freezer.

The VGO and vacuum bottom fractions will be stored in a freezer until recycled. After the test has been completed, the system will be flushed with solvent to clean the unit. The flushing of the system is needed to prevent the residual slurry from solidifying and plugging the unit. After the system is cleaned, shut down will follow the procedure described below. 


\section{PRERUN CHECKLIST}

1. Material safety data sheets are readily available for all materials.

2. Maintenance items have been completed and heat-tracing and insulation are in place.

3. Heater power cords are connected and thermocouple (TC) wires are plugged in.

4. Lock-out/tag-outs have been removed.

5. Areas around equipment are clear of tools, air hoses, combustible materials and other potential trip hazards.

6. Safety eye wash and shower stations are operational and flushed.

7. Personal protective equipment (PPE) are in their proper locations.

8. Two-way radios are operational, and spare batteries have been charged.

9. All raw materials are in place and of adequate supply:
a. Hydrogen six-packs
b. Start-up oil - creosote oil or equivalent
c. Coal
d. Flush solvent

10. Portable area monitors are charged and operational.

11. Purges are on to electrical boxes for adjacent systems.

12. Product gas analyzer is operational.

13. Area monitors for hydrogen and combustibles are operational.

14. Verify that the building ventilation is operational.

15. Spill cleanup kits are in place and properly stocked. 


\section{ANCILLIARY SYSTEM SETUP}

1. Start up the system control/data logging computer, and create a run file with the name shown in the Test Plan (provided by the Project Manager).

2. Turn on flashing lights to alert area personnel to system operation.

3. Turn on hydrogen and combustible gas area monitors; calibrate as necessary.

4. Turn on instrumentation air (and back up $\mathrm{N}_{2}$ ) supply to solenoids and I/P converters.

5. Set purge nitrogen flows to flow control valve electrical boxes.

6. Set purge nitrogen flows to vent lines and knock-out pots.

7. Verify in the field that all automated valves are in the closed position.

8. Verify in the field that all manual valves are in the start-up positions.

9. Verify that all process variables are being displayed properly and that trending screens are operational.

10. Investigate and satisfy all alarm conditions.

11. Turn on cooling water supply and booster pump (as necessary).

12. Turn on product gas analyzer and calibrate. Verify operation at control computer.

13. Start-up gasifier flare according to instructions on wall by ignition control system. Monitor temperatures on the laptop control computer.

14. Set up nuclear-level monitors (level indicator/control [LIC]-402 and LIC-406).

a. Unlock and open source shutter.

b. Power up master evaluation units and verify operation.

15. Check area to verify that nonelectrically rated systems are deenergized.

16. Check indicator board in control room to verify that purges are active for all systems in the pilot plant area. 


\section{SYSTEM LEAK-CHECK WITH HELIUM/NITROGEN BLEND}

1. Set up pressure control system:

a. On Area 100 control screen, toggle pressure control valves (PCV) PCV-418 and PCV420 to manual operation.

b. Stroke PCV-418 and PCV-420 from 0\% open to 100\% open several times; verify response in field.

c. Set PCV-418 and PCV-420 to $0 \%$ open (100\% closed).

d. Verify that hand valve (HV) HV-420 (before PCV-418) and HV-422 (before PCV-420) are closed.

2. Start-up compressor with helium/nitrogen blend:

a. Turn on cooling water to compressor.

b. Verify that all compressor alarms are satisfied.

c. Open valve on helium cylinder to bring helium to the helium mass flow control valve.

d. Open house nitrogen supply valve to bring nitrogen to the nitrogen mass flow control valve.

e. Input helium and nitrogen set points (SPs) at their respective mass flow controllers.

f. Monitor helium pressure on pressure indicator (PI) PI-102 and pressure indicator recorder (PIR) PIR-102.

g. Start compressor and verify automatic start/stop cycling.

3. Set helium/nitrogen blend pressure:

a. Open HV-102 downstream of gas accumulator.

b. Using PIR-106 and PI-106, set regulated helium pressure to 2950 psig using PRV-104.

4. Perform leak-check of reactor hydrogen line and components:

a. Open automated valve (AV) AV-104.

b. Open AV-110.

c. Slowly open HV-110 to bring helium/nitrogen to flow control valve (FCV) FCV-104.

d. Input a low-flow SP ( $<10$ scfh) on FCV-104.

e. Allow PIR-110 and PI-110 to increase to 2950 psig.

f. Close AV-104.

g. Observe PIR-110 and PI-110. Look for leaks between AV-104, HV-106, HV-112, and HV-118.

h. Utilize the LACO Gascheck G3 helium/hydrogen sniffer as necessary.

i. Input a SP of 0 scfh for FCV-104.

j. Close HV-110 and AV-110.

5. Perform leak-check on downstream systems:

a. Open AV-104.

b. Open HV-110.

c. Input a low-flow SP (<10 scfh) on FCV-104.

d. Allow PIR-110 and PI-110 to increase to 2950 psig.

e. Open AV-110. 
f. Slowly open HV-112 to initiate helium/nitrogen flow to the rest of the system.

g. Look for and seal gross leaks.

h. Close HV-102.

i. Observe PIR-106/PI-106, PIR-110/PI-110, PIR-302/PI-302, PIR-304/PI-304, PIR-402/PI-402, and PIR-404/PI-404 for a period of 15 minutes. Look for leaks between HV-102 and HV-420/HV-422.

j. Utilize the LACO Gascheck G3 helium/hydrogen sniffer to find leaks.

6. Vent helium/nitrogen blend from system:

a. Shut down the compressor.

b. Close valve on helium supply cylinder.

c. Close the nitrogen supply valve.

d. Isolate the compressor discharge accumulators.

e. Open HV-462.

f. Slowly bleed system pressure through HV-464.

g. Verify that system pressure is decreasing by observing PIR-106/PI-106, PIR-110/PI110, PIR-302/PI-302, PIR-304/PI-304, PIR-402/PI-402, and PIR-404/PI-404).

7. Put manual and automated valves in start-up mode:

a. Input a SP of 0 scfh for FCV-104.

b. Close HV-108 and HV-112.

c. Close AV-108 and AV-110.

d. Close HV-106 and HV-110.

e. Close PCV-418 and PCV-420.

f. Close AV-104.

g. Close HV-102.

h. Open PRV-104. 


\section{SYSTEM PRESSURIZATION}

1. Set up system pressure control loop:

a. $\quad$ On the Area 400HP control screen, input a pressure control SP of 2500 psig.

b. Toggle to PCV-418 to automatic pressure control.

c. Leave PCV-420 in manual mode with SP of 0\% open/100\% closed.

2. Start-up the compressor:

a. Turn on cooling water to compressor.

b. Open compressor discharge accumulator cylinder valves.

c. Open HV-132 and HV-134 to bring house nitrogen to the compressor.

d. Monitor house nitrogen pressure on PI-112 and PIR-112.

e. Verify that all alarm lights at compressor start/stop panel are satisfied.

f. Verify low pressure (restart) and HP (stop) SPs at compressor.

g. Start compressor and verify automatic start/stop cycling.

h. Monitor the compressor discharge pressure on PI-114 and PIR-114.

3. Set nitrogen source pressure:

a. Open HV-104.

b. Using PIR-116 and PI-116, set regulated nitrogen pressure to 2950 psig using PRV106.

c. Open AV-106 and then AV-114.

d. Slowly open HV-118.

4. Start nitrogen flow to reactor:

a. Open HV-110 to bring nitrogen to FCV-104.

b. Input a low-flow SP (<10 scfh) on FCV-104.

c. Verify flow of nitrogen by watching pressure increase on PIR-110 and PI-110 and flow value on control screen for FCV-104.

d. After indicated flow drops to 0, and PIR-110 and PI-110 pressures have stabilized, open AV-110.

e. Slowly open HV-112 to initiate nitrogen flow to the rest of the system.

f. Slowly increase FCV-104 flow SP until the Test Plan value is attained for reaction hydrogen flow rate.

g. Continue to monitor system pressure and response of PCV-418 (and/or PCV-420).

5. Bring system to operating pressure:

a. Monitor system pressure at PIR-404.

b. Adjust PID values for PCV-418 to obtain the desired pressure control response.

c. Utilize PCV-420 in manual mode as necessary to control system pressure.

d. Open HV-470 and HV-472.

e. Slowly close HV-474 (product gas meter bypass).

f. Monitor product gas flow rate (flow indicator [FI] FI-402) on control screen.

g. Compare nitrogen flow rate values from the FCVs to the calculated product gas rate displayed on control screen. 
6. Start sampling process gas:

a. Open HV-410 in the sample gas line.

b. Verify in the field that the product gas analyzer is getting sufficient sample flow.

c. Verify that the product gas composition is trending toward $100 \%$ nitrogen.

7. Continue to monitor critical system parameters:
a. Nitrogen flow.
b. Product gas flow.
c. System pressure. 


\section{FLUSH SOLVENT PREPARATION}

1. Verify personnel are wearing proper PPE:

2. Load flush solvent to the solvent tank T-206.
a. Open HV-xxx on the flush solvent tank.
b. Transfer flush solvent from the storage vessel to the tank.
c. Close HV-xxx.

3. On the Heat-trace control screen input control SPs for the Area 200 heat-trace lines associated with the flush solvent tank.

4. Initiate recirculation and mixing of flush solvent:

a. On the Area 200 control screen, verify that the input rpm for gear pump P-206 is 0.

b. Turn on P-206 at the control screen.

c. Initiate solvent circulation by slowly increasing pump speed; do not exceed $600 \mathrm{rpm}$.

5. Initiate heating of flush solvent:
a. On the Administration screen, input low and high alarm SPs for the heater controllers and the over-temperature TCs.
b. On the Area 200 control screen, input the ramp rate for flush solvent tank heaters and recycle piping heat-trace.
c. Toggle the heater controllers from manual to auto, and input a control SP in accordance with the Test Plan.
d. Monitor T-206 temperatures and make necessary adjustments to the tank heaters and heat-trace until the solvent temperature attains that prescribed in the Test Plan.




\section{START-UP SOLVENT HEATUP}

1. Turn on cooling water to the slurry mix tank overhead condenser (HX-202).

2. Verify personnel are wearing proper PPE.

3. Load start-up solvent to the slurry mix tank T-202:

a. Tare the scale for the slurry mix tank.

b. Open HV-xxx on the slurry mix tank.

c. Transfer solvent from the storage vessel to the slurry mix tank until the mass prescribed in the Test Plan has been added.

d. Close HV-xxx.

4. Initiate recirculation and mixing of slurry mix tank solvent:

a. On the Area 200 control screen, verify that the input rpm for gear pump P-202 is 0.

b. Turn on P-202 at the control screen.

c. Initiate solvent circulation by slowly increasing pump speed; do not exceed $600 \mathrm{rpm}$.

d. On the control screen, verify the input rpm for mixer M-202 is 0 .

e. Turn on M-202 at the control screen.

f. Initiate solvent mixing by slowly increasing mixer speed; max speed is $345 \mathrm{rpm}$.

5. Initiate heating of start-up solvent:

a. On the Administration screen, input low and high alarm SPs for the heater controllers and the over-temperature TCs.

b. On the Area 200 control screen, input the ramp rate for slurry mix tank heaters and recycle piping heat-trace.

c. Toggle the heater controller from manual to auto, and input a control SP in accordance with the Test Plan.

d. Monitor T-202 temperatures and make necessary adjustments to the tank heaters and heat-trace until the solvent temperature attains that prescribed in the Test Plan.

6. Transfer solvent to slurry feed tank T-204:

a. Tare the scale for the slurry feed tank.

b. Open HV-208 on the transfer line to the slurry feed tank.

c. Observe the scale weight on the slurry feed tank to verify the transfer of solvent; partially or fully close HV-206 on the slurry mix tank recycle line to assist flow to the feed tank.

d. Transfer solvent from the mix tank to the feed tank until the mass prescribed in the Test Plan has been added.

e. Open HV-206 and close HV-208.

7. Initiate recirculation and mixing of slurry feed tank solvent:

a. On the Area 200 control screen, verify that the input rpm for gear pump P-204 is 0.

b. Turn on P-204 at the control screen.

c. Initiate solvent circulation by slowly increasing pump speed; do not exceed $600 \mathrm{rpm}$. 
d. On the control screen, verify the input rpm for mixer M-204 is 0 .

e. Turn on M-204 at the control screen.

f. Initiate solvent mixing by slowly increasing mixer speed; maximum speed is $345 \mathrm{rpm}$.

8. Initiate heating of slurry feed tank solvent:

a. On the Administration screen, input low and high alarm SPs for the heater controllers and the over-temperature TCs.

b. On the Area 200 control screen, input the ramp rate for slurry mix tank heaters and recycle piping heat-trace.

c. Toggle the heater controller from manual to auto, and input a control SP in accordance with the Test Plan.

d. Monitor T-204 temperatures and make necessary adjustments to the tank heaters and heat-trace until the solvent temperature attains that prescribed in the Test Plan.

9. Continue to monitor critical system parameters:
a. Nitrogen flow.
b. Product gas flow.
c. System pressure.
d. Solvent temperature.
e. Heater output.
f. Gear pump performance.
g. Condenser temperatures and coolant flows. 


\section{AREAS 300 AND 400 START-UP}

1. Turn on cooling $\mathrm{N}_{2}$ to HP/high temperature (HT) stripper/separator overheads cooler (HX406):

a. Open HV-442.

b. Control flow with flow indicator/control (FIC) FIC-402 rotameter.

2. Turn on cooling water to the HP/HT stripper/separator overheads cooler (HX-408):

a. Open HV-444.

b. Control flow with FIC-404 rotameter.

3. Turn on cooling water to the bottoms stripper accumulator (BSA) overhead cooler (HX-410):

a. Open HV-458.

b. Control flow with FIC-406 rotameter.

4. Initiate heating of process vessels and heat-trace lines:

a. On the Administration screen, input low and high alarm SPs for the heater controllers and the over-temperature TCs.

b. On the Area 300 control screen, input the ramp rates for slurry and solvent line heattraces.

c. On the Area 400 control screen, input the ramp rates for the HP/HT stripper/separator and BSA process vessels and slurry line heat-trace.

d. Toggle the heater controllers from manual to auto, and input a control SP in accordance with the Test Plan.

e. Monitor temperatures and make necessary adjustments to the vessel heaters and heattrace until the temperatures prescribed in the Test Plan are attained.

5. Start-up fluidizing $\mathrm{N}_{2}$ to sand bath (T-302):

a. Open HV-302 on fluidizing $\mathrm{N}_{2}$ supply line.

b. Set the $\mathrm{N}_{2}$ pressure to 15 psig using pressure relief valve (PRV) PRV-302.

c. Initiate $\mathrm{N}_{2}$ flow to the sand bath through FIC-302.

d. Monitor the bed differential pressure on dPI-308.

e. Adjust FIC-302 to attain a flow rate of $\sim 6 \mathrm{scfm}$

f. Monitor the source $\mathrm{N}_{2}$ pressure on PIR-306/PI-306.

6. Turn on the sand bath heaters:

a. On the Area 300 control screen, verify that the PIR-306 alarm condition is satisfied.

b. On the Administration screen, input low and high alarm SPs for the heater controllers, sand bath temperatures, and the reactor outlet temperatures.

c. On the Area 300 control screen, input the ramp rates for the sand bath heaters.

d. Toggle the heater controllers from manual to auto, and input control SPs.

e. Monitor T-302 temperatures temperature indicator/reactor (TIR) (TIR-322, -324, -326), and make necessary adjustments to the sand bath heaters until the bed temperature attains the start-up value prescribed in the Test Plan. 
7. Turn on the reaction hydrogen preheater:

a. On the Administration screen, input low and high alarm SPs for the heater controller and over-temperature TC.

b. On the Area 300 control screen, input the ramp rate for the electric heater.

c. Toggle the heater controllers from manual to auto, and input a control SP.

d. Monitor the outlet temperature (TIR-304), and make necessary adjustments to the reaction hydrogen preheater until the outlet temperature attains that prescribed in the Test Plan.

8. Continue to monitor critical system parameters:
a. Nitrogen flow.
b. Product gas flow.
c. System pressure.
d. Solvent temperature.
e. Heater output.
f. Sand bath performance.
g. Gear pump performance.
h. Coolant flow and temperature. 


\section{SLURRY PREPARATION}

1. If necessary add more solvent to slurry mix tank T-202.

2. Add recycle bottoms (heavies) to heated start-up solvent:

a. Depressurize feed hopper on solids feeder.

b. Add pulverized recycle bottoms to the feed hopper.

c. Pressure the feed hopper with nitrogen.

d. Slowly open the valve between the solids feeder and the mix tank.

e. Slowly feed bottoms to the mix tank to allow the bottoms to melt and become dispersed in the start-up solvent.

f. Allow bottoms/solvent slurry to mix and circulate until temperatures have stabilized at desired levels.

g. Close the valve isolating the solids feeder and the mix tank.

h. Depressurize the feed hopper.

3. Add coal to heated start-up solvent:

a. Add pulverized coal to the feed hopper.

b. Pressure the feed hopper with nitrogen.

c. Slowly open the valve between the solids feeder and the mix tank.

d. Slowly feed coal to the mix tank to allow the coal to become evenly dispersed in the start-up solvent.

e. Allow the coal/bottoms/solvent slurry to mix and circulate until temperatures have stabilized at desired levels.

f. Close the valve isolating the solids feeder and the mix tank

g. Depressurize the feed hopper.

4. Continue to monitor critical system parameters:

a. Nitrogen flow.

b. Product gas flow.

c. System pressure.

d. Solvent and slurry temperatures.

e. Heater output.

f. Sand bath performance.

g. Gear pump performance.

h. Coolant flow and temperature. 


\section{START-UP SOLVENT PROCESSING}

1. On the Area 200 control screen, verify that the HP pump (P-208) inlet and outlet heat-trace are functional and at temperature.

2. Start pumping start-up solvent (from T-204):

a. Verify that the HP slurry pump is adjusted to a low-stroke length.

b. Open AV-202.

c. Open HV-258.

d. Start HP slurry pump at field start/stop station.

e. Verify solvent pressurization on PI-216/PIR-216.

f. When PI-216/PIR-216 pressure reaches PIR-304/PI-304 pressure, open HV-220.

g. Verify solvent pumping:

- Slurry heat-trace and sand bath temperatures should drop and then rebound as the heaters activate.

- System pressure may become more cyclical because of pump pulsing.

h. Adjust the stroke rate on the HP pump to attain the desired volumetric feed rate as determined from calibration.

3. Monitor liquid levels in the Area $400 \mathrm{HP}$ process vessels:

a. HP/HT stripper/separator pressure valve (PV) (PV-402) level shown by LIC-402.

b. HP/low temperature (LT) separator (PV-404) level shown by LIC-404.

4. Monitor overhead heat exchanger temperatures, and make changes to coolant flows as necessary.

5. Initiate letdown in the HP/HT stripper/separator (PV-402) when the level reaches the SP prescribed in the Test Plan:

a. On the Area 400HP control screen, toggle AV-402 and AV-404 to manual mode.

b. Verify in the field that AV-402 and AV-404 are closed.

c. Slowly open HV-402.

d. Open, then close AV-402 to draw pressurized solvent into the lock.

e. Close HV-402.

f. Open, then close AV-404 to flash solvent from the lock.

g. Toggle AV-402 and AV-404 into automatic mode.

h. Open HV-402 when AV-402 and AV-404 are both closed.

i. Verify solvent letdown/discharge:

- The level trend indicated by LIC-402 should exhibit a saw tooth cycle.

- A slight and cyclic temperature increase may be seen on TIR-416.

j. Monitor solvent level in the BSA by LIC-406.

6. Initiate letdown in the HP/LT separator (PV-404) when the level reaches the SP prescribed in the Test Plan:

a. On the Area $400 \mathrm{HP}$ control screen, toggle AV-406 and AV-408 to manual mode.

b. Verify in the field that AV-406 and AV-408 are closed. 
c. Slowly open HV-404.

d. Open, then close AV-406 to draw pressurized distillate into the lock.

e. Close HV-404.

f. Open, then close AV-408 to flash distillate from the lock.

g. Toggle AV-406 and AV-408 into automatic mode.

h. Open HV-404 when AV-406 and AV-408 are both closed.

i. Verify distillate letdown/discharge:

- The level trend indicated by LIC-404 should exhibit a saw tooth cycle.

- A slight, cyclic temperature may be seen on TIR-436.

j. Monitor solvent level in the BSA by LIC-406.

7. Monitor liquid levels in the Area 400LP process vessels:

a. BSA (PV-406) level shown by LIC-406.

b. Condensate accumulator (CA) (PV-408) level shown by LIC-408.

8. Continue pumping start-up solvent until the level in the slurry feed tank is below $\mathrm{xx} \%$ of capacity and the BSA begins to fill. 


\section{HYDROGEN SYSTEM OPERATION}

1. Set hydrogen source pressure:

a. Open HV-102.

b. Using PIR-106 and PI-106, set regulated nitrogen pressure to 2950 psig using PRV-104.

2. Initiate hydrogen feeding:

a. From the control screen, open AV-106.

b. Close HV-124 shortly after.

c. Verify feeding of hydrogen:

- No permanent change in FCV-104 output.

- No permanent change in system pressures.

- Output on reaction hydrogen preheater increases (due to higher heat content gas relative to nitrogen).

d. Make adjustments to hydrogen flow rates at FCV-104 in accordance with the Test Plan.

e. Monitor the product gas analyzer for the appearance of hydrogen.

f. Monitor area monitors for the possible presence of hydrogen.

g. Continue to make adjustments to the flare as the product gas hydrogen content increases. 


\section{SLURRY PROCESSING}

1. Transfer coal/bottoms/solvent slurry to the slurry feed tank:

a. Open HV-208 on the transfer line to the slurry feed tank.

b. Observe the scale weight on the slurry feed tank to verify the transfer of slurry; partially or fully close HV-206 on the slurry mix tank recycle line to assist flow to the feed tank.

c. Transfer slurry from the mix tank to the feed tank until the level in the slurry mix tank is below $\mathrm{xx} \%$ of capacity.

d. Open HV-206 and close HV-208.

e. Verify slurry pumping:

- No permanent change in system pressures

- Modest changes in slurry preheater output (due to change in heat content relative to solvent only)

2. Allow reactor temperatures to stabilize and slowly increase the fluid-bed (FB) sand bath temperature to attain the reactor conditions prescribed in the Test Plan.

3. Initiate letdown in the BSA (PV-406) when the level reaches the SP prescribed in the Test Plan:

a. On the Area 400LP control screen, toggle AV-410 and AV-412 to manual mode.

b. Verify in the field that AV-410 and AV-412 are closed.

c. Slowly open HV-406.

d. Open, then close AV-410 to draw pressurized bottoms into the lock.

e. Close HV-406.

f. Open, then close AV-412 to flash bottoms from the lock.

g. Toggle AV-410 and AV-412 into automatic mode.

h. Open HV-406 when AV-410 and AV-412 are both closed.

i. Verify bottoms letdown/discharge:

- The level trend indicated by LIC-406 should exhibit a saw tooth cycle.

- A change should be observed in the coolant return temperature on the circulating chiller.

j. Open the bottoms collection pot periodically to verify product recovery.

4. Initiate letdown in the CA (PV-408) when the level reaches the SP prescribed in the Test Plan:

a. On the Area $400 \mathrm{LP}$ control screen, toggle AV-414 and AV-416 to manual mode.

b. Verify in the field that AV-414 and AV-416 are closed.

c. Slowly open HV-408.

d. Open, then close AV-414 to draw pressurized distillate into the lock.

e. Close HV-408.

f. Open, then close AV-416 to flash distillate from the lock.

g. Toggle AV-414 and AV-416 into automatic mode.

h. Open HV-408 when AV-414 and AV-416 are both closed.

i. Verify bottoms letdown/discharge:

- The level trend indicated by LIC-408 should exhibit a saw tooth cycle. 
j. Open the distillate collection pot periodically to verify product recovery.

5. Continue to monitor critical system parameters:
a. Hydrogen flow and source pressure.
b. Product gas flow and composition.
c. System pressure.
d. Slurry temperature.
e. Heater output.
f. Sand bath performance.
g. Gear pump and HP pump performance.
h. Coolant flow and temperature.
i. Liquid levels.
j. Letdown valve operation.
k. Product collection.

5. After system operation and performance has stabilized, prepare another batch of slurry in the slurry feed tank. 


\section{NORMAL SHUTDOWN}

1. Initiate routine for final product collection.

2. Replace hydrogen flow with nitrogen flow:

a. Open HV-124 and close AV-104.

b. Reduce nitrogen flow rates to start-up levels.

3. Monitor product gas composition.

4. Replace slurry flow with flush solvent flow:

a. Open AV-204.

b. Close AV-202.

c. Increase the pumping rate of HP pump P-208 as necessary; do not exceed the letdown limits of the HP separators.

5. After 60 minutes of flush, turn off the FB sand bath heaters. Leave the fluidizing air on.

6. Shut down hydrogen compressor:

a. Isolate hydrogen compressor discharge accumulator.

b. Isolate hydrogen six-pack.

c. Bleed to vent supply and discharge lines from hydrogen compressor.

7. Continue processing with flush solvent for xx minutes.

8. Turn off remaining Area 300 and Area 400 heaters and heat-tracing.

9. Continue processing with flush solvent until system temperatures drop below xxx F.

10. Turn off coolant flows to Area 400 heat exchangers.

11. Shut off cooling water to BSA product collection pot.

12. Depressurize system:

a. Shut off nitrogen flow at FCVs.

b. Put pressure control valves (PCVs) in manual.

c. Gradually open PCVs to bring system pressure down to 0 psig.

13. Drain residual slurry from mix tank T-202:

a. Turn of tank heaters and heat-trace associated with T-202.

b. Shut down recirculation pump.

c. Shut down tank mixer.

d. Drain residual slurry into proper salvage container through HV-256.

14. Drain residual slurry from feed tank T-204: 
a. Turn of tank heaters and heat-trace associated with T-204.

b. Shut down recirculation pump P-204.

c. Shut down tank mixer M-204.

d. Drain residual slurry into proper salvage container through HV-258.

15. Load start-up solvent to the slurry mix tank T-202.

16. Turn on tank heater and heat-trace lines associated with T-202.

17. Initiate recirculation and mixing of slurry mix tank solvent.

18. Transfer solvent to slurry feed tank T-204.

19. Turn on tank heater and heat-trace lines associated with T-204.

20. Initiate recirculation and mixing of slurry feed tank solvent.

21. Repeat Steps 13 through 20 using flush solvent. 


\section{EMERGENCY REACTOR FLUSH}

1. Replace reaction $\mathrm{H}_{2}$ flow with purge $\mathrm{N}_{2}$ flow:

a. Set FCV-104 to 0 scfh.

b. Close AV-110.

c. Set FCV-106 to 5 scfh to help keep gas line free of solids.

2. Reduce slurry feed line heat-trace heater SP.

3. Reduce FB sand-bath heater SPs.

4. Replace slurry feed to HP slurry pump with flush solvent:
a. Open AV-204.
b. Open HV-260 to allow flush solvent to HP slurry pump inlet.
c. Close AV-202.
d. Continue pumping for several minutes to clear the HP pump check valves of solids.

5. Initiate pumping flush solvent through HP flush solvent pump:
a. Open HV-224.
b. Initiate HP pump stroke.
c. Verify pumping of solvent via TIR-332 (HP pump outlet temperature), pulsations in reactor inlet and outlet pressures (PIR-302, -304), and reactor temperatures (TIR-314. -316, -318).

6. Suspend pumping flush solvent through HP slurry pump.
a. Shut off HP slurry pump
b. Close AV-204
c. Close HV-260

7. Increase the flush solvent pumping rate.

8. Continue to monitor the reactor inlet and outlet pressures to observe the pressure differential across the reactor sections.

9. Assess whether operation of the system can be continued.

10. If operation can be sustained, continue with a modified start-up:
a. Return heater SPs to normal conditions.
b. Initiate solvent pumping through the HP slurry pump.
c. Suspend solvent pumping through the HP flush solvent pump.
d. Replace flush solvent with slurry through the HP slurry pump.
e. Replace $\mathrm{N}_{2}$ purge flow with reaction $\mathrm{H}_{2}$ flow and bring to normal flow. 


\section{EMERGENCY SHUTDOWN}

1. Activate all audible and visual alarms if not already tripped.

2. Clear all operations staff (those on the project and others working on adjacent systems) from the pilot plant.

3. Notify Ken Grohs and give current assessment of emergency.

4. Shut off all gas flows $\left(\mathrm{H}_{2}\right.$ and $\left.\mathrm{N}_{2}\right)$ at control computer.

5. Shut off $\mathrm{H}_{2}$ compressor at electrical swing adsorption control computer.

6. Close all gas-blocking valves.

7. Suspend product letdown sequences.

8. Shut off all heaters.

9. Shut off all mixers and gear pumps.

10. Continue to monitor process from the control computer. 


\section{LOSS OF SOLENOID ACTIVATION GAS PRESSURE}

(failure of house air supply)

NOTE:

- The house air supply pressure for solenoids that activate control and blocking valves is measured by PIR-002. Normal house air pressure is $\sim 88$ psig.

- Nitrogen $\left(\mathrm{N}_{2}\right)$ regulated to $\sim 5$ psig lower than the house air pressure is plumbed into the solenoid air supply line. In the instance that the air pressure drops below $\sim 83$ psig, $\mathrm{N}_{2}$ flow will commence to replace air.

- Check valves to prevent reverse flow of the HP gas source into the supply line of the lowerpressure gas.

- Lo and LoLo limit alarms will be programmed for PIR-002 to signal a drop in gas supply pressure.

- $\quad$ The valve positions after loss of air pressure are:

- Hydrogen supply valves (AV-104, -108, -110) - fail closed.

- Nitrogen supply valves (AV-106, -112) - fail open.

- Slurry supply valve (AV-202) - fail closed.

- Solvent flush supply valve (AV-204) - fail open.

- PCVs (PCV-418, -420) - fail open.

- The consequences of the valve position changes are:

- Loss of hydrogen supply.

- Loss of slurry supply.

- System depressurization up to the PCV(s).

- Possible pressurization of vessels downstream of the PCV(s).

- The response to the loss of solenoid activation gas pressure is listed below. The responses requiring input at the computer will be performed manually for the near future. Steps 1 through 6 can be performed by the computer (future) if programmed:

1. Toggle automated $\mathrm{H}_{2}$ valves (AV-104, -108, and -110) to the closed position.

2. Input 0 scfh flow $\mathrm{SP}$ on $\mathrm{H}_{2}$ mass flow controller FCV-104.

3. Toggle automated $\mathrm{N}_{2}$ valves (AV-106 and AV-112) to the open position.

4. Toggle flush solvent supply blocking valve AV-204 to the open position.

5. Toggle slurry supply blocking valve AV-202 to the closed position. 
6. Reduce heater controller SPs (controllers will follow programmed ramp-down rates):

a. Preheaters electrical heater (EH) EH-342 and -344.

b. Sand bath heaters EH-352, -354, -356.

c. Vessel heaters EH-484, -486, -490, -492.

7. Toggle all top lock and bottom lock valve sets from automatic to manual mode (valves default to closed state):
a. AV-402, -404.
b. AV-406, -408 .
c. AV-410, -412 .
d. AV-414, -416 .

8. Close HV-420 upstream of PCV-418 and/or HV-422 upstream of PCV-420.

9. Quickly assess cause of failure and the time required for repair; for repairs lasting longer than 5 minutes, proceed to Step 18.

10. After repair is complete, reset the computer interlock to a normal operating mode (future).

11. Cycle top lock and bottom lock valves (in manual mode) for all separator and accumulator vessels; verify in the field.

12. Open HV-420 (upstream of PCV-418) and/or HV-422 (upstream of PCV-420).

13. Demonstrate control of system pressure through manual cycling of PCV-418 and/or PCV-420.

14. Establish normal system pressure, and toggle over to automatic pressure control.

15. Toggle automated $H_{2}$ valves (AV-104, -108, and -110) to the open position; verify in the field.

16. Slowly establish normal flows on FCV-104.

17. Proceed to Step 31.

18. Establish no more than 25 scfh $\mathrm{N}_{2}$ flow through FCV-106.

19. Control system pressure using $\mathrm{HV}-284$ and $\mathrm{HV}-285$, venting gas to the thermal oxidizer.

20. Continue to monitor LIC-402 on the HP/HT stripper/separator.

21. After repair is complete, reset the computer interlock to a normal operating mode. 
22. Cycle top-lock and bottom-lock valves (in manual mode) for all separator and accumulator vessels; verify in the field.

23. Open HV-420 (upstream of PCV-418) and/or HV-422 (upstream of PCV-420).

24. Demonstrate control of system pressure through manual cycling of PCV-418 and/or PCV-420.

25. Slowly close HV-284 and HV-285.

26. Establish normal system pressure and toggle over to automatic pressure control.

27. Toggle automated $\mathrm{H}_{2}$ valves (AV-104, -108, and -110) to the open position; verify in the field.

28. Slowly establish normal flows on FCV-104.

29. Slowly reduce $\mathrm{N}_{2}$ flow through FCV-106 to 0 scfh.

30. Toggle automated $\mathrm{N}_{2}$ valves (AV-106 and AV-112) to the closed position; verify in the field.

31. Increase preheater, reactor, and vessel heater controller SPs to normal operating condition (controllers will follow programmed ramp-up rates).

32. Toggle the slurry blocking valve (AV-202) to the open position; verify in the field.

33. Toggle the flush solvent blocking valve (AV-204) to the closed position; verify in the field.

34. Resume normal operation. 
APPENDIX A

\section{PROCESS CONTROL COMPUTER SCREEN SHOTS}




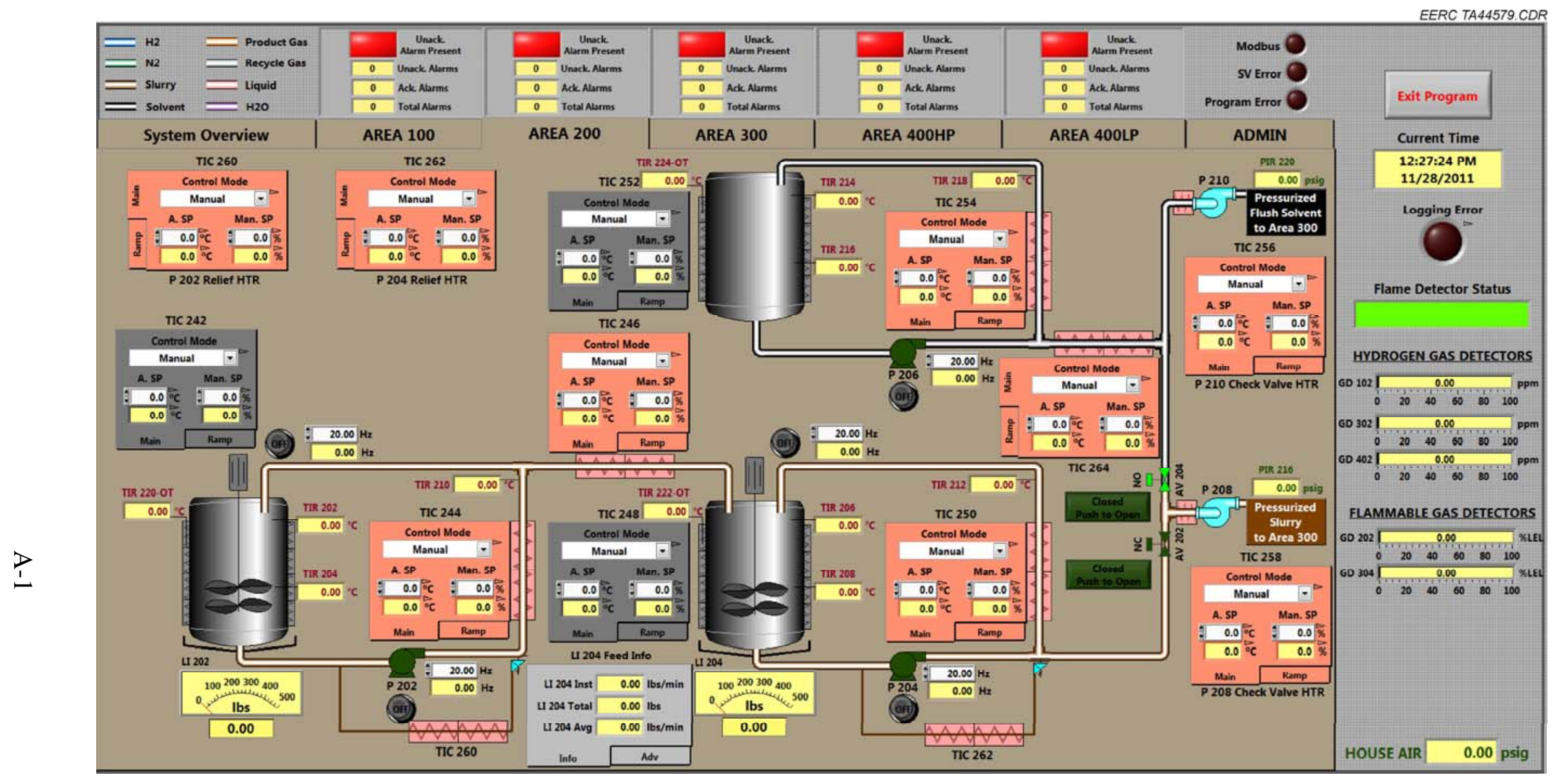

Figure A-1. Area 200 screen. 


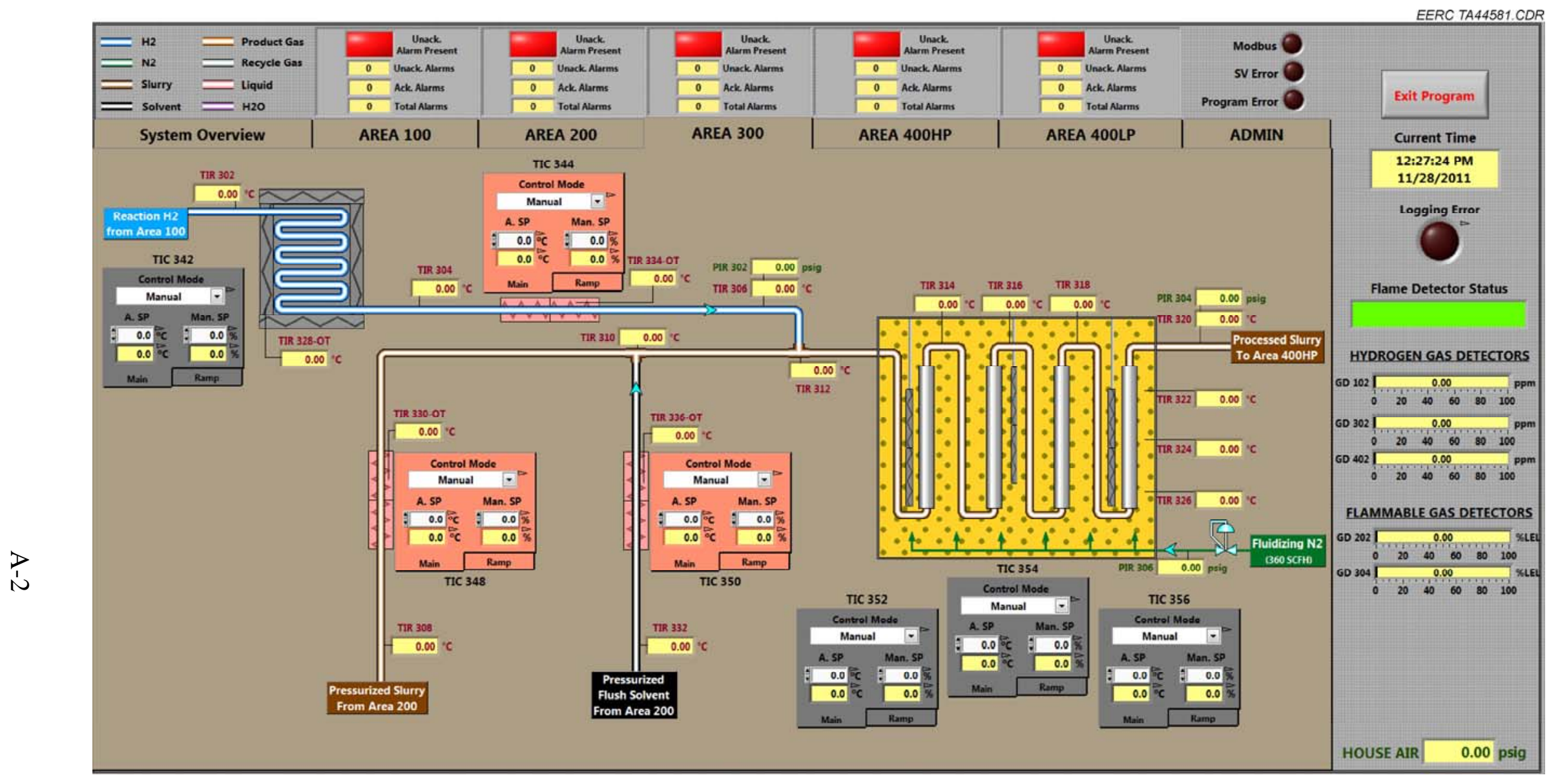

Figure A-2. Area 300 screen. 


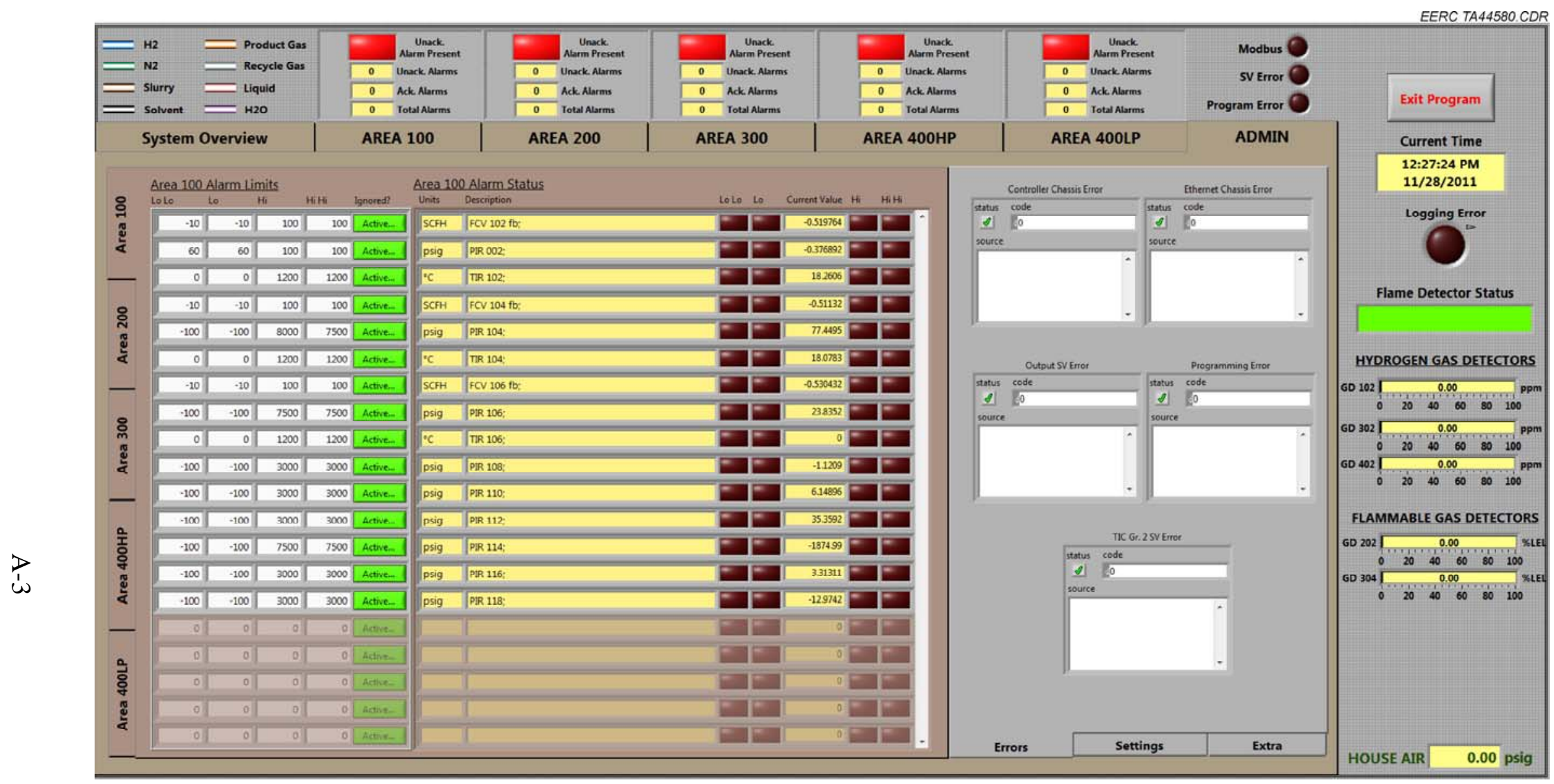

Figure A-3. Administration screen. 
APPENDIX B

\section{START-UP VALVE POSITIONS}




\section{NOMENCLATURE}

$\begin{array}{ll}\text { AV } & \text { automated valve } \\ \text { BSA } & \text { bottoms stripper accumulator } \\ \text { CA } & \begin{array}{l}\text { condensate accumulator } \\ \text { fluid-bed }\end{array} \\ \text { FB } & \text { flow control valve } \\ \text { FCV } & \text { high-pressure } \\ \text { HP } & \text { high-pressure/high-temperature } \\ \text { HP/HT } & \text { high-pressure/low-temperature } \\ \text { HP/LT } & \text { hand valve } \\ \text { HV } & \text { level indicator/controller } \\ \text { LIC } & \text { low pressure } \\ \text { LP } & \text { pressure control valve } \\ \text { PCV } & \text { pressure indicator } \\ \text { PI } & \text { pressure indicator recorder } \\ \text { PIR } & \text { pressure valve control } \\ \text { PVC } & \text { thermal oxidizer } \\ \text { TO } & \end{array}$




\begin{tabular}{|c|c|c|c|}
\hline Area & Tag No. & Valve Name & Start-Up Position \\
\hline Purged Vent Line & HV 002 & First-floor drain valve & $\mathrm{C}$ \\
\hline Purged Vent Line & HV 004 & Second-floor drain valve & $\mathrm{C}$ \\
\hline Dirty Vent Line & HV 020 & Knock-Out Pot 1 drain & $\mathrm{C}$ \\
\hline Dirty Vent Line & HV 022 & Knock-Out Pot 2 drain & $\mathrm{C}$ \\
\hline Dirty Vent Line & HV 024 & 2-inch dirty vent stack drain & $\mathrm{C}$ \\
\hline 100 & HV 102 & Hydrogen supply isolation & $\mathrm{C}$ \\
\hline 100 & HV 104 & Nitrogen supply isolation & $\mathrm{C}$ \\
\hline 100 & HV 106 & & $\mathrm{C}$ \\
\hline 100 & HV 108 & & $\mathrm{C}$ \\
\hline 100 & HV 110 & Reaction hydrogen FCV isolation - inlet & $\mathrm{C}$ \\
\hline 100 & HV 112 & Reaction hydrogen FCV isolation - outlet & $\mathrm{C}$ \\
\hline 100 & HV 114 & Purge nitrogen FCV isolation - inlet & $\mathrm{C}$ \\
\hline 100 & HV 116 & Purge nitrogen FCV isolation - outlet & $\mathrm{C}$ \\
\hline 100 & HV 118 & Hydrogen/nitrogen isolation & $\mathrm{C}$ \\
\hline 100 & HV 124 & $\mathrm{H}_{2}$ supply vent & $\mathrm{C}$ \\
\hline $100 \mathrm{~N}$ & HV 132 & Nitrogen supply isolation & $\mathrm{C}$ \\
\hline $100 \mathrm{~N}$ & HV 134 & Nitrogen supply isolation & $\mathrm{C}$ \\
\hline $100 \mathrm{~N}$ & HV 136 & PIR 114 isolation & $\mathrm{O}$ \\
\hline $100 \mathrm{~N}$ & HV 138 & Nitrogen cylinder valve & $\mathrm{C}$ \\
\hline $100 \mathrm{~N}$ & HV 140 & Nitrogen cylinder valve & $\mathrm{C}$ \\
\hline $100 \mathrm{~N}$ & HV 142 & PI isolation & $\mathrm{O}$ \\
\hline $100 \mathrm{~N}$ & HV 144 & Nitrogen accumulator vent & $\mathrm{C}$ \\
\hline $100 \mathrm{~N}$ & HV 146 & Blocking to Area 100 & $\mathrm{C}$ \\
\hline $100 \mathrm{H}$ & HV 148 & Hydrogen cylinder valve & $\mathrm{C}$ \\
\hline $100 \mathrm{H}$ & HV 150 & Hydrogen cylinder valve & $\mathrm{C}$ \\
\hline $100 \mathrm{H}$ & HV 152 & Hydrogen cylinder bleed valve & $\mathrm{C}$ \\
\hline 100 & AV 104 & Hydrogen accumulator/FCV isolation & $\mathrm{C}$ \\
\hline 100 & AV 106 & Nitrogen accumulator/FCV isolation & $\mathrm{C}$ \\
\hline 100 & AV 108 & & $\mathrm{C}$ \\
\hline 100 & AV 110 & Reaction hydrogen FCV blocking & $\mathrm{C}$ \\
\hline 100 & AV 112 & Purge nitrogen FCV blocking & $\mathrm{C}$ \\
\hline 100 & AV 114 & Hydrogen/nitrogen isolation & $\mathrm{C}$ \\
\hline 200 & HV 202 & Slurry mix tank P-202 inlet & $\mathrm{O}$ \\
\hline 200 & HV 204 & Slurry mix tank P-202 outlet & $\mathrm{O}$ \\
\hline 200 & HV 206 & Slurry mix tank recycle & $\mathrm{O}$ \\
\hline 200 & HV 208 & Slurry feed tank inlet & $\mathrm{C}$ \\
\hline 200 & HV 210 & Slurry feed tank P-204 inlet & $\mathrm{O}$ \\
\hline 200 & HV 212 & Slurry feed tank P-204 outlet & $\mathrm{O}$ \\
\hline 200 & HV 214 & Slurry feed tank recycle & $\mathrm{O}$ \\
\hline 200 & HV 216 & Solvent tank P-206 inlet & $\mathrm{O}$ \\
\hline 200 & HV 218 & Solvent tank P-206 outlet & $\mathrm{O}$ \\
\hline 200 & HV 220 & Slurry line P-208 outlet & $\mathrm{C}$ \\
\hline 200 & HV 224 & Solvent line P-210 inlet & $\mathrm{O}$ \\
\hline 200 & HV 226 & Solvent line P-210 outlet & $\mathrm{C}$ \\
\hline 200 & HV 250 & Slurry mix tank drain & $\mathrm{C}$ \\
\hline 200 & HV 252 & Slurry feed tank drain & $\mathrm{C}$ \\
\hline 200 & HV 254 & Solvent tank drain & $\mathrm{C}$ \\
\hline
\end{tabular}




\begin{tabular}{|c|c|c|c|}
\hline \multicolumn{4}{|c|}{ (continued) } \\
\hline Area & Tag No. & Valve Name & Start-Up Position \\
\hline 200 & HV 256 & Quench pot drain & $\mathrm{C}$ \\
\hline 200 & HV 258 & HP slurry pump - slurry inlet isolation & $\mathrm{C}$ \\
\hline 200 & HV 260 & HP slurry pump - solvent inlet isolation & $\mathrm{O}$ \\
\hline 200 & AV 202 & Slurry cutoff & $\mathrm{C}$ \\
\hline 200 & AV 204 & Flush solvent cutoff & $\mathrm{C}$ \\
\hline 300 & HV 302 & Fluidizing $\mathrm{N}_{2}$ isolation & $\mathrm{C}$ \\
\hline 300 & HV 306 & Blow out - HP dP line & $\mathrm{C}$ \\
\hline 300 & HV 308 & HP leg dP isolation & $\mathrm{O}$ \\
\hline 300 & HV 310 & LP leg dP isolation & $\mathrm{O}$ \\
\hline 300 & HV 312 & Blow out - low pressure dP line & $\mathrm{C}$ \\
\hline 300 & HV 314 & FB fill & $\mathrm{C}$ \\
\hline 300 & HV 316 & FB drain & $\mathrm{C}$ \\
\hline 300 & HV 318 & FB vent stack HX drain & $\mathrm{C}$ \\
\hline 400 & HV 402 & HP/HT separator/stripper - bottoms isolation & $\mathrm{O}$ \\
\hline 400 & HV 404 & HP/LT Separator - bottoms isolation & $\mathrm{O}$ \\
\hline 400 & HV 406 & BSA - bottoms isolation & $\mathrm{O}$ \\
\hline 400 & HV 408 & CA - bottoms isolation & $\mathrm{O}$ \\
\hline 400 & HV 410 & Sample gas line & $\mathrm{C}$ \\
\hline 400 & HV 420 & PCV 418 inlet isolation & $\mathrm{O}$ \\
\hline 400 & HV 422 & PCV 420 inlet isolation & $\mathrm{O}$ \\
\hline 400 & HV 424 & PCV 418 outlet isolation & $\mathrm{C}$ \\
\hline 400 & HV 426 & PCV 420 outlet isolation & $\mathrm{C}$ \\
\hline 400 & HV 430 & HP/HT separator/Stripper drain & $\mathrm{C}$ \\
\hline 400 & HV 432 & HP/LT separator drain & $\mathrm{C}$ \\
\hline 400 & HV 438 & LIC 404 lo-side isolation & $\mathrm{O}$ \\
\hline 400 & HV 440 & LIC 404 hi-side isolation & $\mathrm{O}$ \\
\hline 400 & HV 444 & LIC 404 lo-side drain & $\mathrm{C}$ \\
\hline 400 & HV 446 & BSA drain & $\mathrm{C}$ \\
\hline 400 & HV 448 & CA drain & $\mathrm{C}$ \\
\hline 400 & HV 454 & LIC 408 lo-side isolation & $\mathrm{O}$ \\
\hline 400 & HV 456 & LIC 408 hi-side isolation & $\mathrm{O}$ \\
\hline 400 & HV 460 & LIC 408 lo-side drain & $\mathrm{C}$ \\
\hline 400 & HV 462 & PCV manual bypass to TO & $\mathrm{C}$ \\
\hline 400 & HV 464 & PCV manual bypass to TO & $\mathrm{C}$ \\
\hline 400 & HV 466 & Liquid knock-out drain & $\mathrm{C}$ \\
\hline 400 & HV 468 & Liquid knock-out drain & $\mathrm{C}$ \\
\hline 400 & HV 470 & Gas meter inlet isolation & $\mathrm{C}$ \\
\hline 400 & HV 472 & Gas meter outlet isolation & $\mathrm{C}$ \\
\hline 400 & HV 474 & Gas meter bypass & $\mathrm{O}$ \\
\hline 400 & HV 476 & BSA product collection pot vent isolation & $\mathrm{O}$ \\
\hline 400 & HV 478 & CA product collection pot vent isola. & $\mathrm{O}$ \\
\hline 400 & AV 402 & HP/HT separator/stripper - top lock valve & $\mathrm{C}$ \\
\hline 400 & AV 404 & HP/HT separator/stripper - bottom lock valve & $\mathrm{C}$ \\
\hline 400 & AV 406 & HP/LT separator - top lock valve & $\mathrm{C}$ \\
\hline 400 & AV 408 & HP/LT separator - bottom lock valve & $\mathrm{C}$ \\
\hline 400 & AV 410 & BSA - top lock valve & $\mathrm{C}$ \\
\hline
\end{tabular}




\begin{tabular}{lccc} 
Area & Tag No. & (continued) & Start-Up Position \\
\hline 400 & AV 412 & BSA - bottom lock valve & C \\
400 & AV 414 & CA - top lock valve & C \\
400 & AV 416 & CA - bottom lock valve & C \\
400 & PCV 418 & PCV & C \\
400 & PCV 420 & PCV & C \\
\hline
\end{tabular}


APPENDIX C

COAL LIQUIDS DISTILLATION PROCEDURES AS OF 25 JULY 2012 


\title{
COAL LIQUIDS DISTILLATION PROCEDURES AS OF 25 JULY 2012
}

\author{
Ramesh K. Sharma
}

A semiautomatic distillation system was installed at the Energy \& Environmental Research Center (EERC) to support direct coal liquefaction (DCL) process development activities. The system was designed to enable performance of relatively simple as well as complex ASTM International methods such as D2892 and D5236. Since the system was designed for the distillation of crude oil and petroleum products, its use in coal liquids distillation requires some tailoring of standard methods for efficient and safe operation. This system's automation minimizes the operator time needed to perform the test. The equipment design makes the test straightforward and easier to perform. This system is installed in a laboratory adjacent to the DCL system. It is in a large hood for good ventilation and to make it easier and safer for the technicians to operate and do maintenance and cleaning.

\section{OBJECTIVES}

1. Production of recycle solvent: The primary objective of the unit is to separate the coal liquids produced by the DCL unit into light distillate $\left(<600^{\circ} \mathrm{F}\right)$ and heavy distillate $\left(600^{\circ}-\right.$ $1000^{\circ} \mathrm{F}$ ). The light distillate will be sent to an upgrading facility to convert the coal liquids into usable fuels, and heavy liquid will be used as a recycle solvent for the continuous operation of the DCL unit.

2. Production of fuel samples: The liquid distillate will be upgraded by hydroprocessing comprising hydrotreating and hydrogenation to produce clean fuels. The hydroprocessed distillate will be fractionally distilled in this distillation system according to ASTM standards D86 or D2892 to produce transportation fuels such as naphtha, aviation fuel, and diesel.

This semiautomatic distillation system is installed next to the DCL unit that will be used to distill coal liquids produced from the direct liquefaction of coals to produce recycle solvent or fuels from catalytic upgrading of light distillate. The equipment design makes the test straightforward and easier to perform. The fully assembled distillation unit is shown in Figure C-1.

\section{Distillation Column Configuration}

The packed column configuration will be used to distill the crude oil up to a maximum $450^{\circ} \mathrm{C}$ atmospheric-equivalent vapor temperature. It is sometimes called true boiling point distillation or D2892. This distillation column has 15 theoretical plates and complies fully with ASTM D2892. Although a variety of column packing types are available, including Propak, Helipak, and structured packing, this system has Propak columns. Other packing types are also available. It will have a 12-L pot. Pot sizes of 2 to $100 \mathrm{~L}$ are also available to be used if needed. 


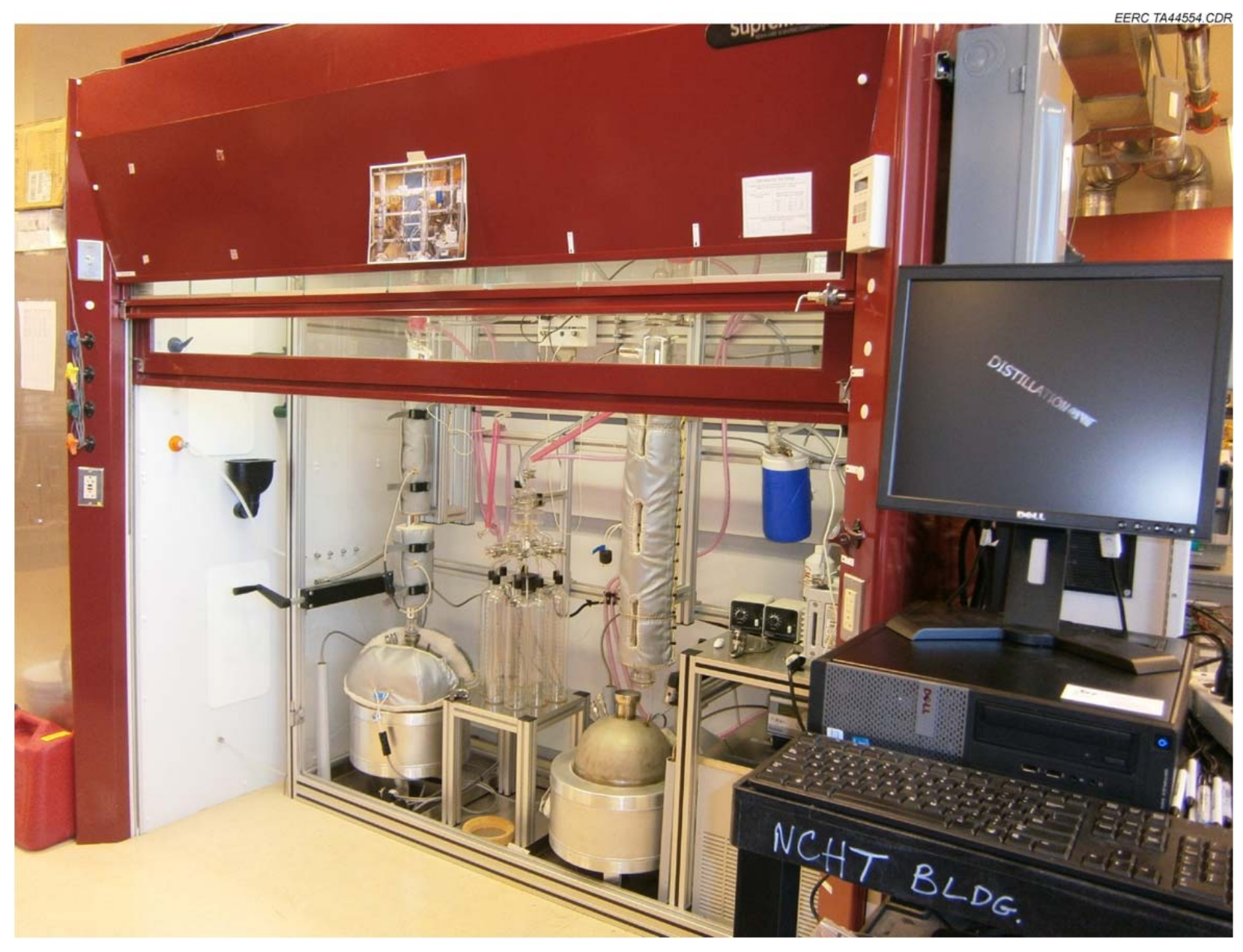

Figure C-1. Off-line distillation system

A spinning band distillation column that can accommodate pot sizes from $10 \mathrm{~L}$ to $12 \mathrm{~L}$ will be installed in addition to traditional packed columns and vacuum pot stills. The vacuum pot still configuration is typically used to distill the residual material from the D2892 distillation out to atmospheric-equivalent vapor temperatures up to $565^{\circ} \mathrm{C}$ or higher. The vacuum pot still complies fully with ASTM D5236. Pot sizes of 1 to 22 liters are available. Because of the quicker turnaround time, this column will be used for distillation to produce recycle solvent to support continuous operation of the DCL unit. Usually, one distillation column is the D2892 packed column (true boiling point) and the other is the D5236 vacuum pot still column. Only one distillation column will be operated at any time. Both distillation columns will share the same controller, fraction collector, vacuum control system, and recirculating bath.

\section{Automation and Accessories}

The crude oil distillation equipment will operate in a semiautomatic mode and will require limited attention, including that of changing the receiver flasks. The option to buy this semiautomatic distillation unit was based on the ease of operation and the lower cost of a fully 
automatic unit. Although this crude oil distillation is semiautomatic, to some extent, it will make the crude oil distillation process easy and efficient from beginning to end.

\section{Microprocessor Controller}

The microprocessor will minimize the amount of operator time required for each crude oil distillation. It can call up your stored programs from one of 19 available memory locations and let the microprocessor perform the crude oil distillation. Each fraction has programmable open and closed temperature cut points, heat rates, and reflux ratio. There is a programmable shutdown at the end of the distillation run. The microprocessor allows easy editing of each of the parameters while the crude oil distillation is in progress.

\section{Fraction Collection}

The fraction collector can automatically collect crude oil fractions based on temperature cut points at atmospheric pressure or under vacuum. Receivers are graduated for easy observation of the cut volume by the operator. The fraction collector that was chosen for this system is an eight-place unit.

\section{Vacuum System}

Distillation of crude oil above $200^{\circ} \mathrm{C}$ must be performed at reduced pressures. The system includes a 2-stage mechanical vacuum pump, cold trap, pressure sensor, and proportional control valve. The operator can input a vacuum set point from $100 \mathrm{~mm}$ of $\mathrm{Hg}$ to $0.1 \mathrm{~mm}$ of $\mathrm{Hg}$, and the vacuum system will automatically control vacuum to the set point level.

\section{Recirculating Bath}

The recirculating bath controls the condenser temperature in the range of $-20^{\circ} \mathrm{C}$ to $100^{\circ} \mathrm{C}$. The operator inputs the desired temperature, and the bath automatically controls the temperature to that set point.

\section{Distillation Procedure}

The distillation system consists of two columns, namely a spinning band column and a packed column. The spinning band column will be used when a simple distillation is desired to fractionally distill the coal liquids to generate only light and heavy distillates, and the packed column will be used for more precise ASTM D86 and D2892 distillations to generate fuel samples. Both of these columns will be attached to the distillation flask via a high-vacuum stopcock to provide easy switching between these two types of distillations as needed.

1. Since the coal-derived liquids have a strong odor and are potential health hazards, all operations must be performed in the hood. Also, extreme care should be taken during collection and transfer of these liquids from the DCL unit to the distillation assembly. If there is a spill, then the area should be vacated, and only skilled operators should clean up the spill 
with disposable wipes and acetone and dispose of the cleanup material as a hazardous substance.

2. Personnel should become familiar with the various components of the distillation system unit and get comfortable with the unit operation. The major components of the distillation unit are shown toward the end of the "Procedure" section.

\section{PROCEDURE}

1. Fill the distillation flask containing a 1-inch egg (or octagonal) stir bar with 6-8 liters of coal liquids. Please make sure the flask is never filled to more than $60 \%$ of its capacity. The flask is placed in the heating mantle, and the heating mantle rests on a stirrer.

2. Attach the appropriate column to the flask, and then complete the rest of the assembly as shown in Figure C-1. In order to have a leak-free assembly, make sure to apply vacuum grease to all ground-glass joints. If there is still a leak in the system, you will be able to quickly know if you are not reaching near-full vacuum each time. If that happens, then make sure to tighten the vacuum tubing with clamps.

3. During this run, you are going to have to insulate your fractionating column. Glass wool is the best heat-resistant insulator. If you find it at your hardware store, make use of it. Fleece also works incredibly well but will not tolerate temperatures above $150^{\circ} \mathrm{C}$. If you expect your oil to come across above that temperature and cannot find glass wool, cotton cloth (such as pieces of a towel or sock) wrapped around the column will suffice. Use wire to keep the insulating material on. If you are distilling your oil at a higher temperature, you will need insulation; otherwise, too much oil will fall back into the distillation pot as reflux. If you have a good vacuum $(<10 \mathrm{~mm} \mathrm{Hg})$ or your column is silvered and vacuum-jacketed, you likely can get away with no insulation.

4. Next, place the three-way adapter on top, then the condenser, then the vacuum adapter, and attach round bottomed flasks to the condenser as the receiving flasks. You should have placed a clamp at the fractionating column and at the receiving flask. If desired, you can optionally place another clamp on the condenser. Last, fit your thermometer to your thermometer adapter (if you are using one) and place your thermometer into the three-way adapter. Get your vacuum ready, but do not connect it or turn it on.

Now, set the stirrer to spin at a high rate, and heat the mantle at a rate that matches the distillation to the temperature at which you expect the coal liquid to come over. The temperature of the heating mantle and the liquid in the distillation pot will be constantly displayed by the digital controller and recorded on the PC. Keep temperature constant. Make sure to control the heating rate to match the distillation of the oil as indicated by the product dripping into the receiver flask. In general, the product should distill in drops (1 to 2 drops/second) rather than stream. If the heating rate is not controlled, then you run the risk of vastly overshooting the point at which the oil is going to come over and it will come over too quickly into the receiver flask. The quick heating may lead to bumping the coal liquid into the receiver flask without any 
fractionation. If this happens, then you have to start all over again. Since the liquefaction product contains water, naphtha, middle distillate, and heavy oil, then it is absolutely necessary to start the initial distillation at ambient pressure. If you are using a spinning band configuration to produce the recycle solvent, then the fractions of interest are as follows:
a. Naptha $\left(<300^{\circ} \mathrm{F}\right)$
b. Middle distillate $\left(350^{\circ}-3650^{\circ} \mathrm{F}\right)$
c. Heavy distillate or recycle solvent $\left(>650^{\circ} \mathrm{F}\right)$

If an upgraded coal liquid is distilled to produce finished fuel, then the distillation will be performed using a packed column. In this case, the fractions of interest are described below:
a. Naptha $\left(<160^{\circ} \mathrm{F}\right)$
b. Naphtha $\left(160^{\circ}-300^{\circ} \mathrm{F}\right)$
c. Jet fraction $\left(300^{\circ}-500^{\circ} \mathrm{F}\right)$
d. Diesel or heavy oil $\left(>500^{\circ} \mathrm{F}\right)$

5. A quick indicator of the changes from one to the other fraction is that no more oil comes out. At this stage, you will have to increase the temperature or increase the vacuum or both so that the next fraction starts to come over. At that point, you will see the temperature on your thermometer climb quickly and hit the temperature at which the send fraction will begin to collect. A good visual indicator of a different fraction starting to come over is that there will be little "swirls" in the receiving flask as the new liquid drips in. This is because the index of refraction of the next fraction is different.

6. Please record the weight of each fraction as well as the residual liquid and pot.

After completion of distillation, make sure the unit is clean for the next distillation. The best way to clean is to use acetone to remove all of the oils, then wash the unit with soapy water (if you feel it necessary). If there is any charring in your distilling flask, rinse with acetone, then let it soak in household ammonia or $10 \%$ sodium hydroxide for a few hours. Then use a brush to easily scrub it out.

Please perform this simple distillation to familiarize yourself with it before using the more complex semiautomatic distillation. This practice is necessary to avoid any damage to the rather expensive unit. 
APPENDIX D

\section{PROCEDURES FOR BATCH DCL-BASED JET FUEL PRODUCTION}




\section{PROCEDURES FOR BATCH DIRECT COAL LIQUEFACTION-BASED JET FUEL PRODUCTION}

\section{INITIAL LIQUEFACTION FOR VACUUM GAS OIL (VGO) PRODUCTION}

Initially, the liquefaction tests of a mixture of predried Illinois No. 6 coal and creosote oil were carried out using sulfided Co-Mo catalyst to produce Illinois No. 6 coal-derived solvent vacuum gas oil (VGO) for subsequent testing of the coal to produce a middle distillate. These tests used solvent to coal ratio of 1.6 bottom mixed with 100 ppm catalyst.

In a typical once-through run, a slurry consisting of approximately $700 \mathrm{~g}$ of dry coal, $998 \mathrm{~g}$ of the solvent VGO, and $1.1337 \mathrm{~g}$ of catalyst was placed in the 2-gallon autoclave equipped with mechanical stirring and hydrogen flow-through capability. The reactor was charged with 1300 psig hydrogen pressure and placed in the heating jacket. The reactor was then heated to the desired temperature; heating continued for 1 hour in a hydrogen flow mode. At the end of the run, the reactor was cooled to room temperature. The gas was discharged through a sodium hydroxide trap (aqueous 10\% $\mathrm{NaOH}$ ) and collected in a gas bag using a wet-test meter. The reactor was opened, and the contents of the reactor were distilled under high vacuum (Figure D-1) to obtain the following fractions:

- Gas fraction (up to C4)

- Naphtha (C5 - $\left.160^{\circ} \mathrm{F}\right)$

- Naphtha $\left(160^{\circ}-350^{\circ} \mathrm{F}\right)$

- Distillate $\left(350^{\circ}-650^{\circ} \mathrm{F}\right)$

- $\operatorname{VGO}\left(650^{\circ}-1000^{\circ} \mathrm{F}\right)$

- Vacuum bottoms $\left(>1000^{\circ} \mathrm{F}\right)$

\section{Liquefaction for Middle Distillate Production}

Once the desired quantities of Illinois No. 6 coal-derived solvent were prepared, further testing was carried out to generate a 1-liter sample of middle distillate for further hydroprocessing/product quality testing to produce a $500-\mathrm{mL}$ jet fuel sample. The tests for producing middle distillate were carried out in a 2-gallon autoclave with flow-through capability.

In a typical bottom-recycle run, a slurry consisting of approximately $900 \mathrm{~g}$ of the dry coal, $802 \mathrm{~g}$ of vacuum bottoms obtained from initial testing, $802 \mathrm{~g}$ of the solvent VGO, and $0.60 \mathrm{~g}$ of catalyst was placed in the 2-gallon autoclave equipped with mechanical stirring and hydrogen flow-through capability. The reactor was charged with 1300 psig hydrogen pressure and placed in the heating jacket. The reactor was then heated to the desired temperature, and heating continued for 1 hour in a hydrogen flow mode. At the end of the run, the reactor was cooled to room temperature. The gas was discharged through a sodium hydroxide trap (aqueous $10 \%$ $\mathrm{NaOH}$ ) and collected in a gas bag using a wet-test meter. The reactor was opened, and the contents of the reactor were distilled under high vacuum to obtain the following fractions: 


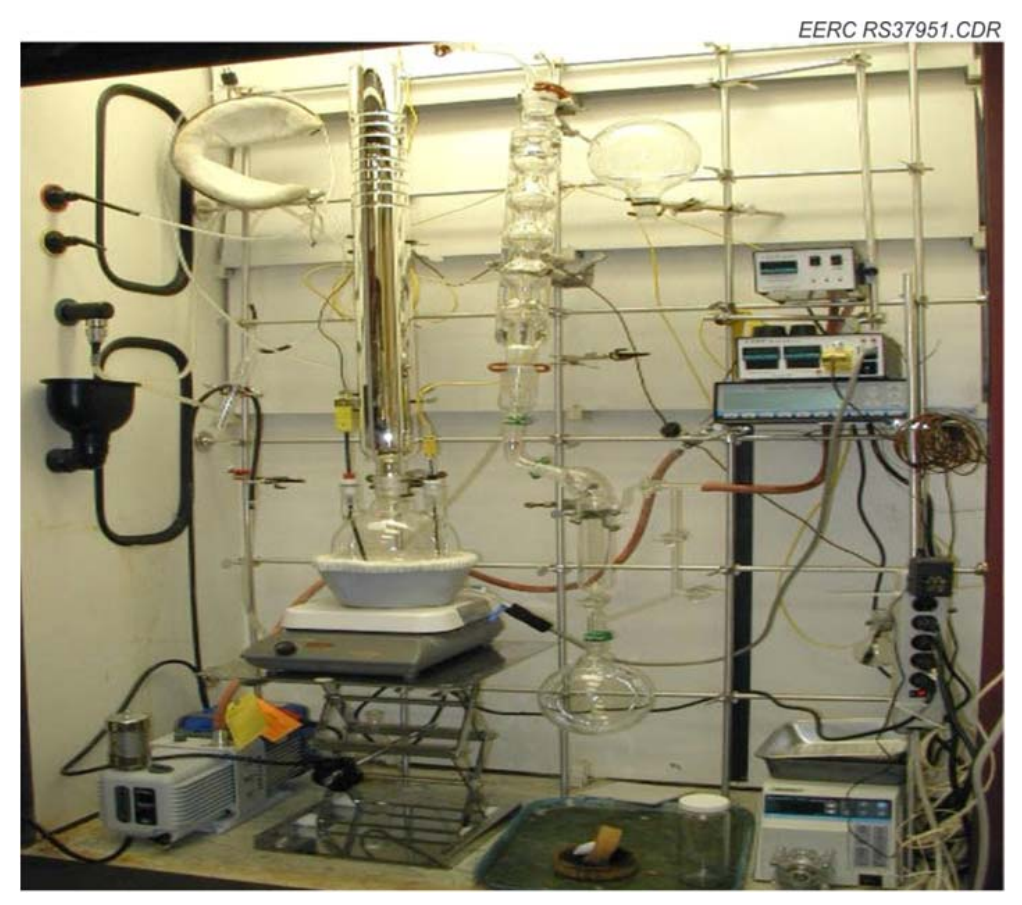

Figure D-1. Bench-scale fractional distillation system.

- Gas fraction (up to C4)

- Naphtha $\left(\mathrm{C} 5-160^{\circ} \mathrm{F}\right)$

- Naphtha $\left(160^{\circ}-350^{\circ} \mathrm{F}\right)$

- Distillate $\left(350^{\circ}-650^{\circ} \mathrm{F}\right)$

- $\operatorname{VGO}\left(650^{\circ}-1000^{\circ} \mathrm{F}\right)$

- Vacuum bottoms $\left(>1000^{\circ} \mathrm{F}\right)$

\section{UPGRADING OF COAL DISTILLATE}

The middle distillate produced from the direct liquefaction of coal was upgraded by a twostage catalytic hydrotreatment and saturation to produce naphthenic fuel derived from coal.

\section{Hydrotreating}

The catalytic hydrotreatment of the middle distillate $\left(350^{\circ}-650^{\circ} \mathrm{F}\right)$ using KF-841 catalyst was carried out in a small continuous reactor (SCR) described in Figure D-2 to produce JP-8compliant jet fuel. Hydrotreatment of the middle distillate was carried out to remove heteroatoms such as nitrogen, sulfur, and oxygen along with hydrocracking and hydrogenation. Initial tests were conducted using middle distillate produced from once-through and first bottom-recycle runs (slop) to validate the catalysts and reactor system and optimize the conditions. The hydrotreatment was carried out in a tubular reactor packed with KF-841 (Ni-Mo) catalyst supplied by Albemarle. The catalyst was diluted with an equal volume of glass beads. The catalyst packing, presulfidation, and operating conditions are described below: 


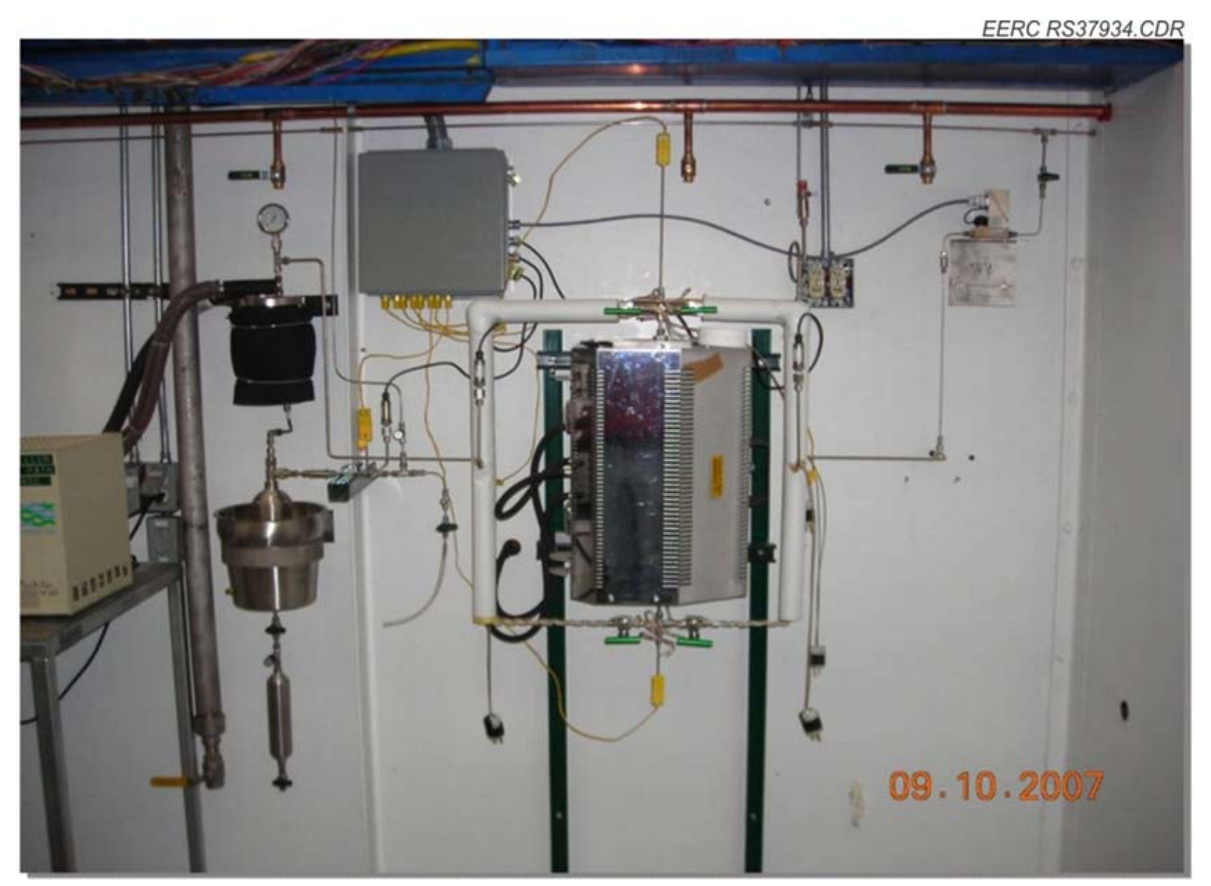

Figure D-2. SCR system.

\section{Procedure}

Note: Requires 24-hr continuous unit operation coverage.

1. Install reactor in upflow mode of operation.

2. Place feed pump in Plexiglas box (or equivalent) to maintain a constant feed temperature (i.e., constant density).

3. Place two liquid drain pots (accumulators) in service for alternating product collection from the condenser.

4. Suggest installing double-block values (if not already) on both product drain (accumulator) pots.

5. If available, install online analyzer to monitor $\mathrm{H}_{2} \mathrm{~S}$ breakthrough during catalyst sulfiding step.

6. If analyzer is not available, provide a port to use a Dräger pump and tube for $\mathrm{H}_{2} \mathrm{~S}$ detection.

\section{Hydrotreating Run (Stage 1) Is as Follows:}

1. Unit preparation

a. Rinse out unit without reactor inline.

b. Pressure test: cold with $\mathrm{N}_{2}$ to 2500 psig. 
c. Pressure test: cold with $\mathrm{H}_{2}$ to 2500 psig.

d. Check $\mathrm{H}_{2}$ /distillate feed flow calibrations.

e. Load catalyst in reactor ( $24 \times 45$ mesh crushed, 1:1 crushed inert dilution; Figure D-3).

f. Install reactor and pressure-test: cold with $\mathrm{H}_{2}$ to 2500 psig.

\section{Unit operations}
a. Dry out catalyst in reactor ( 8-hr heatup and hold at $300^{\circ} \mathrm{F}$ ).
b. Wetting catalyst with surrogate distillate $\left(\sim 4 \mathrm{hr}\right.$ at $\left.250^{\circ} \mathrm{F}\right)$.
c. Heatup and two-step catalyst activations (dimethyldisulfide [DMDS] in surrogate distillate) $\sim 16 \mathrm{hr}$.
d. Line-out and activity check with "off-spec.” distillate.
e. Switch to "on-spec." distillate.
f. Off-spec. hydrotreated (HT) product collection (for Stage 2 break-in feed).
g. Switch to on-spec. HT product collection.

3. Distillate inspection
a. Product distillation, if deemed necessary (save $350^{\circ} \mathrm{F}$ )
b. Product analysis $\left(\mathrm{H}_{2} \mathrm{~S}\right.$ and $\mathrm{NH}_{3}$ stripped, if no distillation performed)
c. Product evaluation (for confirming/adjusting Stage 2 conditions)

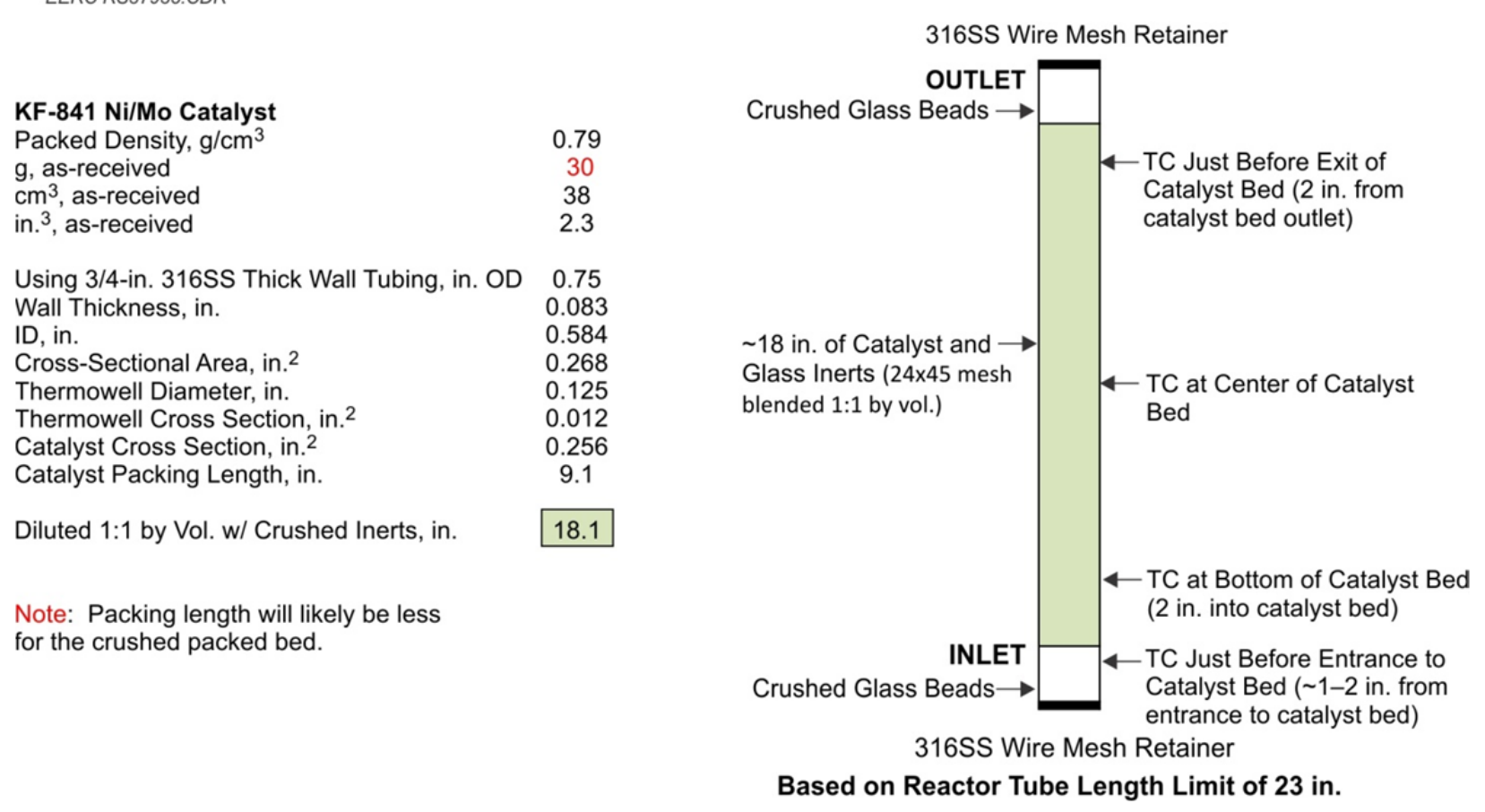

Figure D-3. Packed-bed tubular reactor for hydrotreating of middle distillate

(TC is thermocouple). 


\section{Start-Up Procedure}

1. Water-wash the start-up distillate to remove $\mathrm{Cl}$ (use a separation funnel with at least three washes, until $\mathrm{Cl}<20$ ppm by x-ray fluorescence).

2. Dry catalyst in situ.

3. Purge unit with inert gas $\left(\mathrm{N}_{2}\right)$ after pressure testing.

4. Pressure $\mathrm{H}_{2}$ to 300 psig.

5. Set $\mathrm{H}_{2}$ rate to $270 \mathrm{~cm}^{3}$.

6. Heat to $300^{\circ} \mathrm{F}$ at $50^{\circ} \mathrm{F} / \mathrm{hr}$ rate.

7. Check knock-out (KO) pot for water and drain.

8. Maintain at $300^{\circ} \mathrm{F}$ for at least $1 \mathrm{hr}$.

9. Check KO pot for water and drain.

10. When little or no water is in pot, lower temperature to $250^{\circ} \mathrm{F}$.

11. Introduce distillate feed at $15 \mathrm{~cm}^{3} / \mathrm{hr}$ to wet the catalyst.

12. Continue wetting for $4 \mathrm{hr}\left(\sim 60 \mathrm{~cm}^{3}\right.$ of distillate).

13. Collect and save the wetting distillate to reuse for catalyst break-in use.

14. Blend sulfiding distillate one pump bath at a time to minimize distillate use for sulfiding step.

15. Add 1.5\% sulfur as DMDS to water-washed start-up distillate (2.25 g DMDS per $100 \mathrm{~g}$ distillate).

16. Increase reactor temperature to $450^{\circ} \mathrm{F}$ (take care not to overshoot by more than a few degrees).

17. Replace break-in distillate with sulfiding distillate feed at $15 \mathrm{~cm}^{3} / \mathrm{hr}$ when close to $450^{\circ} \mathrm{F}$.

18. Hold temperature at $450^{\circ} \mathrm{F}$ (take care not to allow any exotherm to exceed $475^{\circ} \mathrm{F}$, which can promote coking and metal oxide reduction).

19. Begin to continuously monitor product gas for $\mathrm{H}_{2} \mathrm{~S}$ breakthrough with online laser analyzer or with a $\mathrm{H}_{2} \mathrm{~S}$ Dräger tube (caution - because of high $\mathrm{H}_{2} \mathrm{~S}$ concentrations, use a proper face mask and vacuum snorkel trunk). 
20. Continue to sulfide until a steady, copious breakthrough of $\mathrm{H}_{2} \mathrm{~S}$ is observed ( $3000 \mathrm{ppm}$ ).

21. Empty KO pot as needed and save the product (caution - because of high $\mathrm{H}_{2} \mathrm{~S}$ concentrations, use a proper face mask and vacuum snorkel trunk).

22. Once $\mathrm{H}_{2} \mathrm{~S}$ breakthrough is observed, increase temperature to $650^{\circ} \mathrm{F}$ at $25^{\circ} \mathrm{F} / \mathrm{hr}$ ( $\sim$-hr heatup time).

23. Hold until $\mathrm{H}_{2} \mathrm{~S}$ breakthrough is steady at $>1000 \mathrm{ppm}$ in the product gas.

24. Replace sulfiding feed with break-in feed.

25. Adjust process conditions to program settings.

\section{Procedure}

1 Adjust process conditions to program run conditions.

2 Allow $4 \mathrm{hr}$ of initial line-out with break-in distillate feed $\left(\sim 60 \mathrm{~cm}^{3}\right)$.

3 Switch to alternate product accumulator pot.

4 Drain sample from first pot into glass bottle and label with time and date (caution - this sample will contain $\mathrm{H}_{2} \mathrm{~S}$ ).

5 Purge product to remove $\mathrm{H}_{2} \mathrm{~S}$ and $\mathrm{NH}_{3}$ ( $\sim 30$ min of mild $\mathrm{N}_{2}$ bubbling) in enclosed lab hood (repeat this procedure with each subsequent sample).

6 Continue to collect a product sample every $4 \mathrm{hr}$ ( 10 samples total over 2 days of line-out).

7 During the line-out period, adjust reactor temperature in accordance with instructions to meet product targets.

8 When line-out feed is consumed, switch to "on-spec." program distillate feed ( $\sim-6$ days of operation).

$9 \quad$ Continue with above sampling procedure every $4 \mathrm{hr}$ until instructed otherwise.

10 Adjust reactor temperature as needed to meet product targets.

11 Sampling intervals may be extended based on analytical test feedback.

12 Combine distillate product glass bottle samples from line-out operations as instructed.

13 Combine distillate product glass bottle samples from program operations as instructed. 
14 Submit both products for final analytical tests indicated in the "Analytical Targets" sheet.

15 Note: Save all liquid samples, including the distillate from sulfiding operation after stripping out $\mathrm{H}_{2} \mathrm{~S}$.

After the desired amount of middle distillate was hydrotreated, a gentle stream of nitrogen was bubbled through the sample to remove the dissolved ammonia and hydrogen sulfide produced during the process. The sample was analyzed by simulated gas chromatography distillation (GCD) and gas chromatography-mass spectroscopy (GC-MS), elemental analysis, and density measurement.

\section{Saturation}

The product from Stage 1 hydrotreatment contained almost 30\% aromatic components. In order to produce a fully naphthenic jet fuel, the hydrotreated product was further hydrogenated using a saturation catalyst, Criterion 654 catalyst. The hydrogenation was carried out in a SCR described above. The catalyst diluted with an equal volume of glass beads was packed in the reactor as shown in Figure D-4. The reaction procedure is described below.

EERC RS37936.CDR

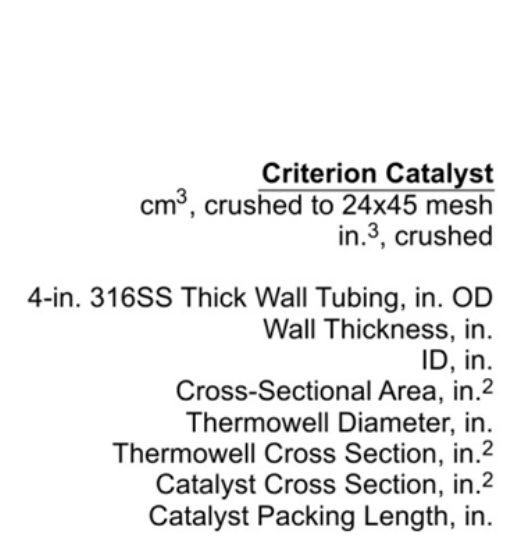

Diluted 1:1 by Vol. w/ Crushed Inerts, in. Approx Diluted Bed Volume, $\mathrm{cm}^{3}$

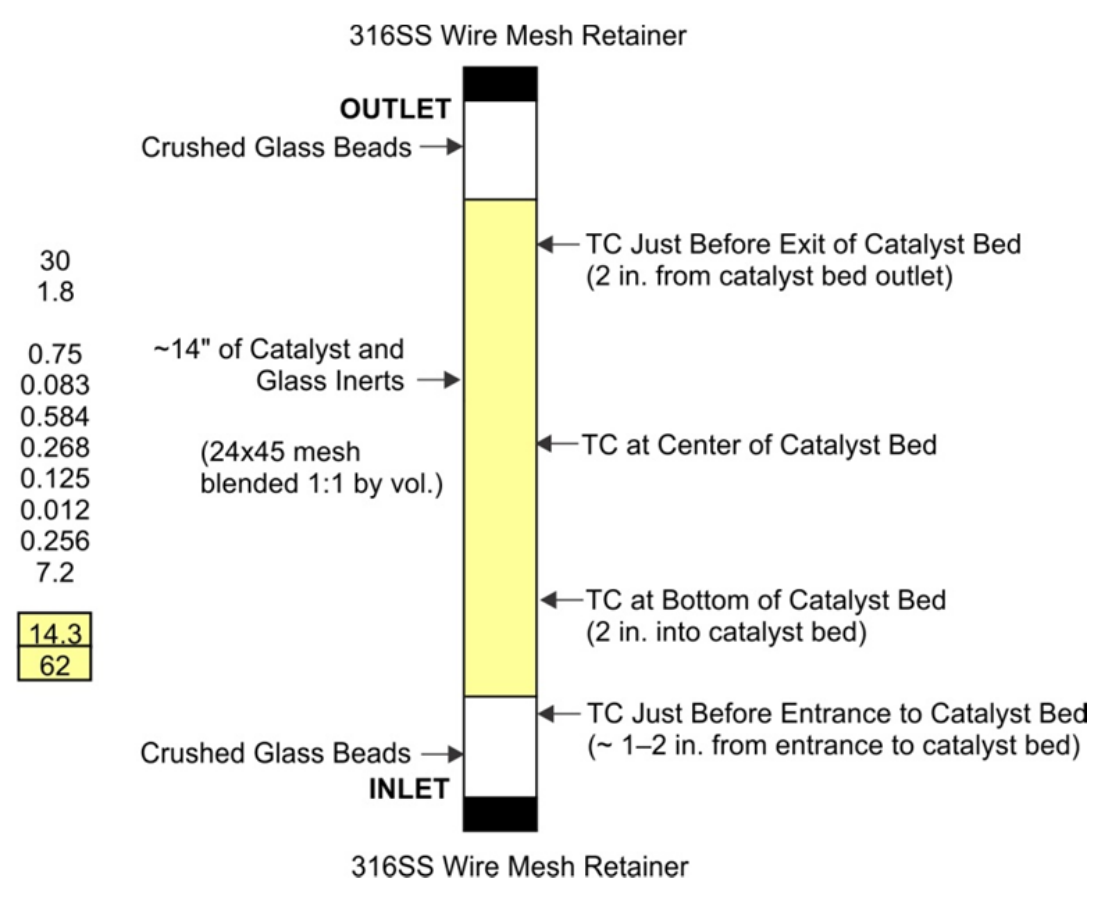

Figure D-4. Packed-bed tubular reactor for saturation of hydrotreated middle distillate. 


\section{Saturation Run (Stage 2 upgrading) Procedure}

Catalyst preparation:

1. Measure out and record weight of $30 \mathrm{~cm}^{3}$ of "as-received" catalyst.

2. Crush catalyst to $24 \times 45$ mesh size.

3. Crush enough catalyst with an equal volume of $24 \times 45$ mesh crushed Pyrex beads.

4. Load the 1:1 by volume mixture into the reactor as indicated in the reactor diagram.

Catalyst activation of criterion's recommendation procedure:

1. Install reactor after pressure testing unit.

2. Start nitrogen flow through unit at ambient pressure.

3. Heat reactor to $500^{\circ} \mathrm{F}\left(260^{\circ} \mathrm{C}\right)$ and hold for $1 \mathrm{hr}$ - caution do not exceed $545^{\circ} \mathrm{F}\left(285^{\circ} \mathrm{C}\right)$ in the reactor.

4. After $1 \mathrm{hr}$ at $500^{\circ} \mathrm{F}$, cool to $300^{\circ} \mathrm{C}\left(150^{\circ} \mathrm{C}\right)$ with nitrogen still flowing.

5. At $300^{\circ} \mathrm{F}$, switch from nitrogen to hydrogen flow.

6. Adjust unit conditions to $1500 \mathrm{psig}$ and $785 \mathrm{~cm}^{3}$ hydrogen feed rate.

7. Hold at $300^{\circ} \mathrm{F}\left(150^{\circ} \mathrm{C}\right)$ for $4 \mathrm{hr}$.

8. After $4 \mathrm{hr}$ at $300^{\circ} \mathrm{F}$, increase temperature to $525^{\circ} \mathrm{F}\left(275^{\circ} \mathrm{C}\right)$ at $50^{\circ} \mathrm{F} / \mathrm{hr}\left(28^{\circ} \mathrm{C} / \mathrm{hr}\right)$.

9. Hold at $525^{\circ} \mathrm{F}\left(275^{\circ} \mathrm{C}\right)$ for at least $2 \mathrm{hr}$.

10. Cool to $300^{\circ} \mathrm{F}\left(150^{\circ} \mathrm{C}\right)$.

11. At $300^{\circ} \mathrm{F}\left(150^{\circ} \mathrm{C}\right)$, start the distillate feed at $33 \mathrm{~cm}^{3} / \mathrm{hr}$.

\section{AROMATIC SATURATION CONDITIONS}

- Temperature: $300^{\circ} \mathrm{F}$

- Pressure: 1500 psig

- Hydrogen feed: $785 \mathrm{~cm}^{3}$

- Liquid flow: $33 \mathrm{~cm}^{3} / \mathrm{hr}$

- Liquid hourly space velocity: 0.532 
After the desired amount of middle distillate has been saturated, a gentle stream of nitrogen was bubbled through the sample to remove any dissolved ammonia and hydrogen sulfide produced during the process. The water was separated from the saturated product. The sample was analyzed by simulated GCD and GC-MS, elemental analysis, and density measurement.

\section{Preparation of Jet Fuel Sample}

The product obtained from two-stage hydrotreatment of middle distillate was fractionated, and the jet fraction was analyzed by various American Society for Testing and Materials standards to evaluate compatibility with JP-8 specifications. After a series of fractional distillations and analysis, the fraction distilling in $250^{\circ}-475^{\circ} \mathrm{F}$ was found to meet most of the JP-8 specifications tested so far. This sample was mixed with a renewable (canola) oil-derived isoparaffin-rich jet fuel blendstock at a blend ratio of about $60 \%$ coal-derived material- $40 \%$ renewable oil-derived material to produce a composite fuel. This fuel was tested in-house to evaluate target properties of petroleum-derived jet fuel (JP-8). After confirming that the sample met the target specifications for JP-8, the sample was submitted to Air Force Research Laboratory for evaluation. 
APPENDIX E

\section{SYSTEM SHAKEDOWN PLANS}




\section{SYSTEM SHAKEDOWN PLANS}

\section{SYSTEM SHAKEDOWN}

The purpose of the system shakedown is to make sure that all components of the unit are working as expected. The system should be able to perform at high temperature and high pressure for extended periods of time. The shakedown is a five-part operation:

1. An initial direct coal liquefaction (DCL) system leak check will be performed using nitrogen, with insulation off the fittings, tubing, and vessels so that each connection and joint can be checked. Initial leak checks will be performed with nitrogen at ambient temperature at pressures of 500, 1000, 1500, 2000, and, finally, at 2750 psig. Leaks will be located using a combination of an ultrasonic leak detector and bubbleproducing leak-detecting solution. Follow-up pressure checks will be conducted at 2750 psig using a blend of nitrogen and helium. Helium will act as a surrogate for hydrogen. A LACO GasCheck G3 hand-held thermal conductivity helium/hydrogen sniffer will be used to detect leaks. A final leak check will be performed at 2500 psig using hydrogen.

2. After verifying that the system can hold pressure, functionality of the level-monitoring systems on the product collection vessels as well as functionality of the liquid letdown valves and system pressure control valves will be assessed. These tests will be performed at ambient temperature and at pressures of ambient to 2750 psig under a nitrogen atmosphere. Hydrogenated anthracene oil will be used as the test liquid at a nominal pumping rate of 2 liter/hour $\left(34 \mathrm{~cm}^{3} / \mathrm{min}\right.$ ). (This rate is determined on the basis of a 60 -minute residence time for the oil in the reactors).

3. Similar tests to those of Step 2 will then be performed at operating temperature and pressure. The system will be heated to $450^{\circ} \mathrm{C}$ with nitrogen at $2750 \mathrm{psig}$, and another series of leak checks will be performed. The system will then be cooled down to $200^{\circ} \mathrm{C}$, after which the nitrogen will be replaced with hydrogen and the pressure reduced to 2500 psig. Pumping of hydrogenated anthracene oil will then be initiated at a nominal 2-liter/hour flow rate. The temperature of the reactor system will be increased to $312^{\circ} \mathrm{C}$ at a heat up rate of $56^{\circ} \mathrm{C} / \mathrm{hr}$ and then to a final temperature of $450^{\circ} \mathrm{C}$ at $28^{\circ} \mathrm{C} / \mathrm{hr}$. Testing with anthracene oil will be conducted for a minimum of 2 hours, allowing the desired liquid levels in the separators to be achieved and steady level and pressure control attained.

4. Subsequent shakedown testing will be performed using a slurry consisting of solvent and coal (solvent/coal ratio $=3.2$ ), again at 2 liter/hour $\left(34 \mathrm{~cm}^{3} / \mathrm{min}\right)$. As satisfactory system performance is attained, the solvent/coal ratio will be incrementally reduced until a ratio of 1.6 (solvent/coal) is attained.

5. If the shakedown using a solvent/coal mixture is successful, the slurry mixture will be modified by adding vacuum bottoms. The initial slurry will consist of a solvent/coal/ 
bottoms ratio of $1 / 1 / 0.5$ with the ratio increased to $1 / 1 / 1$. All tests will be conducted for at least 2 hours at a 2 -liter/hour $\left(34-\mathrm{cm}^{3} / \mathrm{min}\right)$ slurry flow rate.

In addition to monitoring all system pressures, temperatures, and liquid and gas flow rates, the effectiveness of the stripping hydrogen and stripping recycle gas for effecting the proper product separations will be assessed. The bottoms and condensate removed during Steps 4 and 5 will be processed (see distillation manual) to allow for recycle and product evaluation.

\section{PRODUCTION OF MIDDLE DISTILLATE}

Once a successful shakedown is completed, the system is ready for production of distillate fuel. Initially a "once-through operation" will be performed using a slurry consisting of solvent/coal (ratio $=1.6$ ) and a $100-\mathrm{ppm}$ catalyst. The slurry will be fed to the system for 24 hours to generate 50 pounds of vacuum gas oil and bottoms each for use in the "bottom recycle run." For the bottom recycle run, a slurry consisting of solvent/coal/bottom (ratio $=1 / 1 / 1)$ and a 100-ppm catalyst will be pumped for 10 hours to generate enough condensate to produce approximately $3 \mathrm{~L}$ of middle distillate upon distillation of the condensate. 